\title{
„WSPÓŁCZEŚNI GLADIATORZY”. PRÓBA OKREŚLENIA ISTOTY I KULTUROWEGO ZNACZENIA PROFESJONALNEGO WRESTLINGU ${ }^{1}$
}

JOANNA BIERNACIK

joanhagen@gmail.com

\section{PROLOG - GLADIATORZY NA POGRANICZU ŚWIATÓW}

Fałszywy sport. Prostacki teatr. Udawanie bólu za wielkie pieniądze. Zapasy profesjonalne, potocznie zwane po prostu wrestlingiem, choć śledzone przez miliony osób na całym świecie, wciąż wzbudzają kontrowersje wśród przypadkowych odbiorców. Niniejszy artykuł stanowi próbę uchwycenia istoty i kulturowego znaczenia tego pozornie nieskomplikowanego sportu. Jak zauważa Dariusz Kosiński, widowiska sportowe często są lekceważone i marginalizowane jako potencjalny przedmiot badań, sprowadzane do roli czczej rozrywki i bezproduktywnej zabawy ${ }^{2}$. Przekonanie to wydaje się wypływać z ignorowania faktu, iż są one istotną częścią życia społecznego. Kosiński postrzega sport jako „najpełniejszą reprezentację współczesnej kultury światowej”3, stanowiącą „najpełniejszy, najbardziej precyzyjny w swojej złożoności metakomentarz dotyczący jej podstawowych wartości, znaczeń i sposobów działania"4. Dziedzinę, która zawiera w sobie złożoną płaszczyznę performatywną - co badacz ukazuje na przykładzie meczu piłki nożnej. Skoro Kosiński postuluje ustanowienie sportu jako dziedziny

1 Artykuł stanowi przeredagowaną wersję rozprawy magisterskiej napisanej pod kierunkiem prof. UKSW dr hab. Brygidy Pawłowskiej-Jądrzyk i obronionej na Wydziale Nauk Humanistycznych UKSW w 2017 roku.

2 D. Kosiński, Performatyka i dramatologia sportu. Próba przewrotki teoretycznej, „Kultura Współczesna” 2017, nr 1, s. 15.

3 Ibidem, s. 16.

4 Ibidem. 
centralnej dla badań z zakresu performatyki, warto zatem przyjrzeć się także profesjonalnemu wrestlingowi ${ }^{5}$ - dyscyplinie wciąż w Polsce mało znanej, jednakże wartej opisania, łączącej w sobie cechy zarówno widowisk sportowych, jak i teatralnego performansu. To dyscyplina pozornie prosta, wręcz prostacka, skrywająca jednak pod tą fasadą mnogość interesujących, nieoczywistych kontekstów.

Niniejszy tekst składa się z pięciu części. Pierwsza poświęcona jest krótkiej rekonstrukcji historii analizowanej dyscypliny. Zarysowuję tam okoliczności powstania i kontekst społeczny popularyzacji wrestlingu w różnych kręgach kulturowych - każda odmiana regionalna nieznacznie różni się bowiem od pozostałych, co uzależnione jest od lokalnych tradycji, uwarunkowań kulturowych i geopolitycznych. Tłumaczę także podstawową terminologię, jaka funkcjonuje w żargonie środowiska zapaśniczego.

Następnie staram się przybliżyć zasady, jakimi rządzi się owo widowisko - od aspektu pozornej przepisowości i przezroczystości formy, przez swoisty regulamin pokazów - zarówno w kontekście konstrukcji reżyserowanych pojedynków, jak i zakulisowej polityki (która niezmiennie pobudza wyobraźnię widzów) - aż po wątki związane z kampowym i kontrkulturowym charakterem tego typu rozrywki.

Część trzecia dotyczy roli cielesności w pro wrestlingu. Ciało performera jest bowiem nie tylko, co podpowiada intuicja, nośnikiem znaków, ale i znakiem samym w sobie - aparycja zawodnika pozostaje pierwszym bodźcem wizualnym odbieranym przez widza - a także pewną formą wypowiedzi. Zajmuję się także zagadnieniem kobiecości i męskości, jak i problemem stereotypii w przedstawieniu Innego. Zapasy, jako dziedzina inkluzywna i egalitarna, okazują się jednocześnie przestrzenią transgresji - jak pokazują

5 W środowisku fanowskim skrótowo nazwanym najczęściej „wrestlingiem” bądź „pro wrestlingiem” - określenia te ugruntowane są w kręgach związanych z opisywaną dyscypliną, w związku z czym w dalszych częściach artykułu stosowane będą przeze mnie wymiennie. Istnieje również synonimiczne pojęcie „wolnoamerykanka”, wywodzące się z rodzaju zapasów catch, w których dozwolone są wszelkie chwyty; w literaturze zastosował je m.in. Adam Dziadek, tłumacząc dotyczący profesjonalnych zapasów szkic Rolanda Barthes’a, jednakże w kontekście współczesnego wrestlingu wykorzystuje się je bardzo rzadko i powszechnie uważa za przestarzałe. 
przykłady indywiduów szczególnie ekscentrycznych, nie ma w tej dziedzinie granic, których nie da się przekroczyć, ani norm, które nie podlegałyby subwersji, co odbywa się oczywiście z zachowaniem pozornej równości. Jednym z najistotniejszych aspektów zapasów jest - jak wskazuję za Rolandem Barthes'em - semantyczna przezroczystość. Znaki i komunikaty odczytywane są na bieżąco, w ferworze walki nie ma bowiem czasu na pogłębioną analizę. Każdy gest, cios ma być zrozumiały dokładnie w momencie jego wymierzenia, a samo widowisko jest - podobnie jak przedstawienie teatralne - niepowtarzalne, wykonywane wobec zawsze innej, unikalnej publiczności ${ }^{6}$. Uproszczenia i schematy są więc nieuniknione.

Warto zwrócić uwagę na zagadnienie intermedialnego charakteru analizowanej przeze mnie dyscypliny, manifestowanego przez liczne nawiązania i odwołania do innych tekstów i zjawisk kultury popularnej. Wrestling głównego nurtu zawsze ściśle związany był z aktualnymi trendami i przemianami społeczno-kulturowymi, nieodłącznie czerpał z coraz to nowszych mód, skupiając drobne ekscentryzmy jak w soczewce i niejako stanowiąc pewnego rodzaju metakomentarz otaczającej rzeczywistości. Zajmuję się także fenomenem Santo - meksykańskiego luchadora, który stał się dla odbiorców w swoich czasach swoistym herosem, a zarazem społecznym pedagogiem.

Ostatnia część artykułu poświęcona jest z kolei zagadnieniu profesjonalizacji wrestlingu w Polsce. W ostatniej dekadzie można bowiem zauważyć stopniowy wzrost zainteresowania owym widowiskiem, sygnalizowany przez zwiększoną aktywność internetowej społeczności fanowskiej i stosunkowo łatwy dostęp do treści. Ponadto swoją działalność rozwijają amatorskie kluby, powstają pierwsze szkółki treningowe umożliwiające adeptom poznanie podstaw praktyki dyscypliny w bezpiecznych warunkach, organizowane są pierwsze profesjonalne pokazy. Wiele wskazuje na to, iż oddane grono pasjonatów, choć stosunkowo niewielkie (wręcz znikome, jeśli porównać jego liczebność z rozmiarami środowisk fanowskich innych sportów), jeszcze długo pozostanie aktywne.

Materiał zgromadzony w niniejszym tekście prezentuje wrestling jako zjawisko wielowarstwowe, skrywające mnogość interesujących kontekstów

${ }^{6}$ D. Kosiński, op. cit., s. 20

7 Ibidem., s. 16. 
kulturowych i społecznych pod pozorami czczej, nieskomplikowanej rozrywki. Niszowy charakter widowiska przekłada się na skromną literaturę przedmiotu podejmującą wskazany wątek.

\section{CZYM JEST PROFESJONALNY WRESTLING?}

Profesjonalny wrestling jest widowiskiem, które od lat z podekscytowaniem śledzą miliony ludzi na całym świecie. Także w Polsce - choć pozostaje zjawiskiem raczej niszowym, posiada relatywnie niewielką, acz oddaną grupę miłośników. Pomimo wciąż rozszerzającego się rynku, w potocznym myśleniu na temat tej dyscypliny utarło się wiele stereotypów, mitów i krzywdzących uproszczeń.

\subsection{OD JARMARCZNEJ ZABAWY DO OGÓLNOŚWIATOWEGO FENOMENU - KRÓTKA HISTORIA WRESTLINGU}

Brakuje danych, które pozwoliłyby na konkretne umiejscowienie narodzin wolnoamerykanki w czasie. Pierwsze ślady formującej się dyscypliny datuje się zwykle na ostatnie dekady XIX wieku. Wówczas, niezależnie od siebie, rozwijały się dwa rodzaje widowisk, które dały podstawy temu, co dziś znamy pod pojęciem rozrywki wrestlingu.

Walter Armstrong, autor jednej z pierwszych znanych publikacji dotyczących tematyki zapasów ${ }^{8}$, już pod koniec XIX wieku opisał szereg zróżnicowanych odmian europejskiego stylu zapasów, w tym niemiecką czy francuską, a ponadto - odmianę japońską. We wstępie Armstrong zaznacza, że pierwsze próby popularyzacji dyscypliny łączącej najważniejsze nurty angielskiej tradycji zapaśniczej podjął już w 1871 roku niejaki J.G. Chambers, jednak bez wymiernego skutku9 . Większość swojej niespełna sześćdziesięciostronicowej rozprawy, zatytułowanej po prostu Wrestling, Armstrong poświęca ośrodkom brytyjskim, którym nazwy nadaje od miasta bądź regionu, gdzie rozwijały się stowarzyszenia zapaśników. W kolejnych rozdziałach zdradza tajniki stylów: Cumberland, kornwalijskiego, Lancashire i szkockiego, nada-

8 Pierwsze wydanie ilustrowanego kompendium pochodzi z 1890 roku i zostało opublikowane nakładem wydawnictwa Fredericka A. Stokesa. W 2011 roku zostało ono poddane procesowi digitalizacji, dzięki czemu obecnie dostępne jest w domenie publicznej w serwisie Google Books.

9 W. Anderson, Wrestling, New York 1890, s. 14. 
jąc im wspólną nazwę - za Chambersem - catch-as-catch--can (dosłownie: „chwytaj, jak możesz chwycić”, choć można tłumaczyć tę frazę także jako: „wszystkie chwyty dozwolone"). Pojedynki opisywane przez Armstronga opierały się przede wszystkim na tak zwanym grapplingu, to jest walce wręcz bazującej na podstawowych chwytach, rzutach i dźwiginiach, jednak w przeciwieństwie do klasycznych zapasów, dopuszczalne były także zagrania powszechnie uznawane za nieprzepisowe - uderzenia, kopnię-

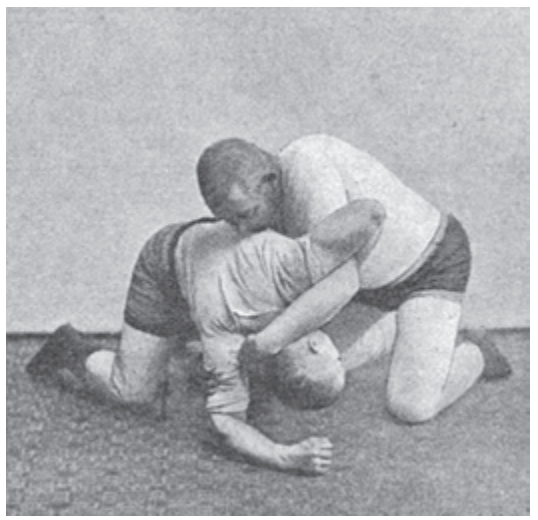

Il. 1. Połowiczny nelson - jedna $z$ dźwigni stosowanych $w$ walkach stylu catch cia, a nawet łapanie za włosy lub inne wrażliwe części ciała (chętnie wykorzystywane przez adeptów słynącej ze szczególnej brutalności odmiany francuskiej oraz szkoły Lancashire ${ }^{10}$ ). Walki catch nie były symulowane; zwyciężał ten, kto - w zależności od preferowanego stylu i ustalonych zasad - pierwszy powalił przeciwnika na matę lub zmusił go do poddania się.

W tym samym czasie w Stanach Zjednoczonych lokalne jarmarki i obwoźne trupy cyrkowe wzbogaciły się o nową atrakcję - improwizowane wyzwania. Siłacze o rzekomo nadludzkiej tężyźnie fizycznej stawali na scenie, podczas gdy wodzirej rozpoczynał poszukiwanie ochotników wśród lokalnych mieszkańców i uczestników jarmarku. Warunki zakładu były banalnie proste - jeśli ochotnik zdołał wytrzymać pięć minut pojedynku z gigantem, wygrywał. Jeśli nie - pula zakładu trafiała w ręce wodzireja ${ }^{11}$. Wraz ze wzrostem zainteresowania wydłużał się także czas trwania atrakcji - zamiast jednego pojedynku inicjowano dwa, następnie trzy, by ostatecznie poświęcić widowisku osobne stanowisko.

Sharon Mazer zwraca uwagę na istotę elementu autopromocji - siłacz występujący na scenie nie mógł być po prostu siłaczem. Atleta, wybierając

10 Ibidem, s. 29.

11 Zob. S. Mazer, Professional Wrestling. Sport and Spectacle, Jackson (MS) 1998, s. 23. 


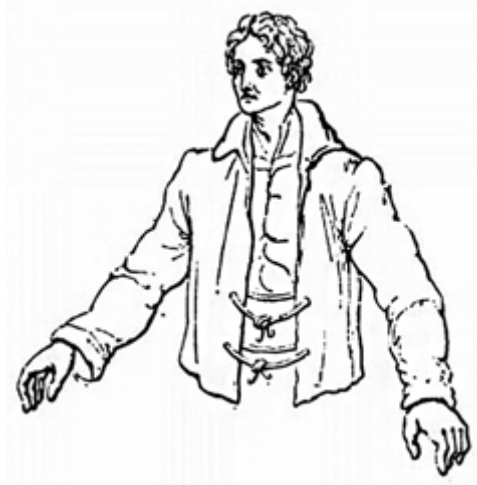

Il. 2. Kornwalijski strój zapaśniczy

cechy rozpoznawcze (mógł to być chociażby wyrazisty kostium lub łatwy do zapamiętania przydomek), konstruował swoisty mit legitymizujący status odgrywanej przez siebie scenicznej persony ${ }^{12}$. Zawodników catch także obowiązywał określony ubiór. Każda ze szkół wypracowała unikatowy kod wizualny wyróżniający ją na tle innych ośrodków. Przywdziewając dany kostium, adepci podkreślali swoją przynależność do wybranej drużyny ${ }^{13}$.

Na początku XX wieku catch uznany został za dyscyplinę olimpijską. Na Igrzyskach Olimpijskich w St. Louis (1904) był jedynym rodzajem zapasów, podczas gdy w Londynie (1908) i w Antwerpii (1920; pod nazwą freeestyle wrestling) wystąpił obok zapasów klasycznych. Fakt ten można uznać za symboliczne rozdzielenie zapasów amatorskich klasycznych od profesjonalnych, czyli wrestlingu.

Po przestoju spowodowanym II wojną światową, w drugiej połowie lat 40. XX wieku nastąpił dynamiczny rozwój pro wrestlingu, nazywany także Pierwszą Złotą Erą. W tym czasie w Stanach Zjednoczonych uformował się tak zwany system terytorialny (ang. territories) - siatka średniej wielkości klubów organizujących pokazy wrestlingu przeznaczone dla mieszkańców wielkich miast i ich okolic. Porzucono także element sportowej rywalizacji na rzecz widowiskowości pojedynku, a kulisy organizowanych pokazów (tak zwane kayfabe) objęto ścisłą tajemnicą. W 1948 roku powstała National Wrestling Alliance - pierwsza federacja zapaśnicza zrzeszająca niezależnych promotorów. NWA ułatwiała przepływ zawodników pomiędzy członkami unii i ujednoliciła listę tytułów mistrzowskich, zwiększając tym samym ich prestiż.

Dzięki upowszechnieniu telewizji, w latach 50. lokalne kluby zyskały możliwość dotarcia do większej niż kiedykolwiek grupy odbiorców. Pokazy,

${ }_{12}$ Ibidem, s. 24.

13 W. Armstrong, op. cit., s. 19. 
dotąd dostępne jedynie na żywo, emitowane były w ogólnokrajowych sta$\mathrm{cjach}^{14}$. Pro wrestling doskonale odpowiadał potrzebom nowego medium: był rozrywką łatwą $\mathrm{w}$ odbiorze, okraszoną zarówno elementami komediowymi, jak i dramatycznymi. Na korzyść promotorów przemawiały także niskie koszty produkcji tego typu programów. Nadpodaż treści szybko doprowadziła jednak do przesycenia rynku i - co za tym idzie - stopniowego spadku zainteresowania masowej publiczności. Pod koniec lat 50. większość audycji o tematyce zapaśniczej została usunięta $\mathrm{z}$ ramówek lub przesunięta na późne godziny nocne.

Złota Ery przełomu lat 40. i 50. XX wieku objęła nie tylko amerykańskie kluby. To także okres dynamicznego rozwoju nurtów zagranicznych meksykańskiego lucha libre i japońskiego puroresu. To lata świetności ikon i pionierów tychże nurtów: El Santo, który jeszcze przed zakończeniem kariery doczekał się statusu ludowego bohatera ${ }^{15}$, i Rikidōzana, określanego mianem „Ojca Puroresu”.

Po trwającej blisko trzy dekady stagnacji i okresie powolnego rozwoju organizacji zapaśniczych kolejny przełom nastąpił na początku lat 80 . XX wieku. Vincent K. McMahon, idąc w ślady swojego ojca i dziadka, w 1979 roku wraz z żoną Lindą zakłada organizację Titan Sports. Już trzy lata później wykupuje większość udziałów w Capitol Wrestling Corporation ${ }^{16}$, przejmując władzę nad wchodzącymi w jej skład organizacjami terytorialnymi, w tym prowadzoną przez jego ojca, Vincenta J. McMahona, World Wrestling Federation. Plany promotora były ambitne - zamierzał bowiem wyprowadzić WWF ponad podział terytorialny, aby docelowo osiągnąć zasięg globalny. By wcielić swój plan w życie, McMahon junior zaczął wykupywać największe nazwiska występujące w konkurencyjnych organizacjach (w tym Terry'ego Bolle, szerzej znanego pod pseudonimem Hulk Hogan). Pokazy WWF

14 W latach 1948-1955 każda z dostępnych w Stanach Zjednoczonych stacji telewizyjnych posiadała w ramówce przynajmniej jeden program związany z pro wrestlingiem.

${ }^{15} \mathrm{O}$ fenomenie El Santo piszę więcej w części czwartej - Pro wrestling w kulturze popularnej.

16 Założone w 1953 roku przez Vincenta McMahona seniora i Jamesa Mondta CWC; podobnie jak NWA było unią zarządzającą organizacjami terytorialnymi na terenie stanów znajdujących się na północnym wchodzie USA. 


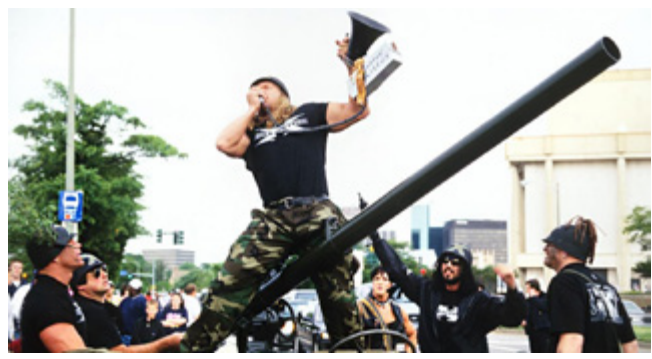

Il. 3. Widowiskowa przesada. W trakcie emisji programu grupa D-Generation $X$ wypowiada wojne konkurencyjnej organizacji

emitowano w telewizji publicznej, co przyczyniło się do wielkiego wzrostu zainteresowania wrestlingiem. McMahon określił swój produkt mianem rozrywki sportowej (sports entertainment), podkreślając dualistyczny charakter tej dyscypliny. Chcąc dotrzeć do szerszej grupy odbiorców, promotor nawiązał współpracę z gwiazdami branży muzycznej (między innymi piosenkarką Cyndi Lauper) - kooperacja ta przeszła do historii jako okres Rock \& Wrestling Connection ${ }^{17}$.

Wskutek drastycznej ekspansji i polityki agresywnego zwalczania konkurencji World Wrestling Federation szybko zyskało status monopolisty na amerykańskim rynku, stopniowo przejmując kolejne bankrutujące organizacje terytorialne. Promotorzy wchodzący w skład unii NWA próbowali ratować swoją sytuację, wspólnie organizując pokaz specjalny - Starrcade, pierwszy event określany mianem supercard, to jest składający się z szeregu pojedynków o wysokim prestiżu ${ }^{18}$. Los mniejszych organizacji wydawał się jednak przesądzony. Wkrótce prezes największej z nich, Jim Crockett, ogłosił bankructwo, a sama federacja (Jim Crockett Promotions) została w 1988 roku wykupiona przez imperium medialne Teda Turnera i przekształcona w World Championship Wrestling ${ }^{19}$.

Dzięki otrzymanemu wkładowi finansowemu WCW w krótkim czasie zagroziła monopolowi federacji McMahonów. Aby zmierzyć się z konkurencją, cotygodniową audycję WCW - Nitro - przesunięto na poniedziałkowe wieczory. W tym samym czasie WWF emitowało swoją audycję - Raw.

${ }^{17}$ O kolaboracji WWF z branżą muzyczną i jej skutkach więcej piszę w dalszej części artykułu, zatytułowanej Rock \& Wrestling Connection.

${ }_{18}$ W pokazie wzięły udział największe gwiazdy organizacji zrzeszonych w NWA. Na trybunach Greensboro Colliseum zasiadło przeszło szesnaście tysięcy widzów.

19 Fakt ten uważany jest za symboliczną śmierć systemu terytorialnego. 
Decyzja ta zapoczątkowała blisko sześcioletnie zmagania, podczas których obie organizacje walczyły ze sobą o uwagę widzów, nierzadko uciekając się do sensacji ${ }^{20} \mathrm{i}$ kontrowersji ${ }^{21}$. Okres ten nazywany jest mianem „poniedziałkowych wojen" (Monday Night Wars). Zacięta walka o widza doprowadziła do diametralnej zmiany charakteru prezentowanej treści. WWF odeszło od karykaturalnie przerysowanych postaci i prostych historii opartych na walce dobra ze złem - konwencji przyjaznej rodzinom i młodszej publiczności. W specjalnym oświadczeniu Vince McMahon ogłosił nadejście nowej epoki - tak zwanej Ery Attitude. Program adresowany był przede wszystkim do widowni nastoletniej i młodych dorosłych. Prezentowane tam treści charakteryzowały się wzmożoną brutalnością, wulgaryzacją oraz występowaniem tak zwanych shootów - przemówień zdradzających kulisy biznesu, wykraczających poza scenariusz lub sprawiających wrażenie nieplanowanych ${ }^{22}$. Audycje utrzymywały dzięki temu pozór nieprzewidywalności.

${ }^{20} \mathrm{Na}$ porządku dziennym było między innymi „podkradanie” zawodników konkurencyjnej organizacji. Kontrakty większości zawodników nie zawierały wówczas klauzuli o zakazie konkurencji, w związku z czym skuszeni lepszymi warunkami performerzy mogli z tygodnia na tydzień zmienić miejsce pracy bez narażania się na wysokie kary finansowe i odpowiedzialność prawną.

${ }^{21}$ Wyniki oglądalności obu programów były przedmiotem cotygodniowej dyskusji w branżowych mediach. Obie organizacje za wszelką cenę starały się utrzymać widzów po swojej stronie, co nierzadko prowadziło do sytuacji kuriozalnych. 27 kwietnia 1998 roku ubrani w barwy militarne członkowie grupy D-Generation $\mathrm{X}$ wsiedli do czołgu i udali się do sąsiedniego miasta, skąd emitowany był program WCW - Nitro. Przejazd na bieżąco relacjonowany był podczas audycji Raw. Na miejscu grupa oficjalnie wypowiedziała konkurencyjnej organizacji wojnę. Z kolei 4 stycznia 1999 roku komentatorzy Nitro zdradzili wynik walki wieczoru konkurencyjnego programu, podczas której miało dojść do zmiany posiadacza pasa mistrzowskiego. Spiker kilkukrotnie powtórzył tę informację, ironicznie odnosząc się do nowego mistrza. Plan przyniósł skutek odwrotny do zamierzonego - ponad sześćset tysięcy widzów zmieniło kanał, by zobaczyć ten pojedynek. Tego dnia Raw po raz pierwszy od dwóch lat osiągnęło wyższą oglądalność niż Nitro, a WCW już nigdy nie pokonało WWF w potyczce na ratingi.

22 Zmianie uległo także podejście widzów do tego typu treści, do czego przyczyniła się mnogość mediów branżowych i zdobywające coraz większy zasięg specjalistyczne fora internetowe. Na przełomie lat 90. i dwutysięcznych odbiorcy zaczęli 
Okres Monday Night Wars to czas rekordowych wyników oglądalności pro wrestlingu. W szczytowym momencie zaciętą rywalizację organizacji każdego tygodnia w samych Stanach Zjednoczonych śledziło średnio od pięciu do siedmiu milionów widzów ${ }^{23}$. Konflikt ten dobiegł końca w 2001 roku, gdy McMahonowie wykupili upadające WCW, po czym wygasili konkurencyjną markę. W tym samym roku promotorzy nabyli także prawa do trzeciej co do wielkości organizacji zapaśniczej - Extreme Championship Wrestling, ponownie zapewniając WWF trwający do dziś monopol w branży.

Żadna z federacji nigdy nie zdołała już powtórzyć sukcesu czasów Monday Night Wars. Zmianie ponownie uległ także sam produkt - współczesny wrestling powrócił do idei egalitaryzmu publiczności, a promotorzy dbają o możliwie jak największe zróżnicowanie treści w celu maksymalnego rozszerzenia docelowej grupy odbiorców. Rozwój Internetu przyczynił się również do rozwoju organizacji niezależnych i zagranicznych, znacznie ułatwiając dostęp do produkowanych przez nie treści ${ }^{24}$.

\subsection{TERMINOLOGIA}

Roland Barthes tak pisał o wrestlingu w swoich Mitologiach:

Są ludzie, którzy uważają, że wolnoamerykanka to sport prostacki. Ale wolnoamerykanka nie jest sportem, tylko widowiskiem, a udział w dawanym przez nią przedstawieniu Bólu nie jest większym prostactwem niż dzielenie cierpień z Arnolfem lub Andromachą. Istnieje oczywiście fałszywa wolnoamerykanka, rozgrywana za wielkie pieniądze z zachowaniem

być świadomi działania zakulisowej polityki i mechanizmów rządzących biznesem. Nową podgrupę odbiorców świadomych owej konwencji nazwano smart marks (w skrócie smarts lub smarks; od angielskiego słowa smart - 'bystry', 'sprytny').

${ }^{23}$ Najwyższy zarejestrowany przez agencję ratingową Nielsen wynik oglądalności padł 10 maja 1999 roku i wyniósł 8.1 punktu. Oznacza to, że audycję Raw tego dnia oglądano statystycznie w 9,3 miliona amerykańskich domostw. Przelicznik Nielsena wynosi 1,15 miliona domostw na 1 punkt. http://www.2xzone.com/ratings/ rawhistory.shtml\#.WYT8E1VJbDe [dostęp: 19.03.2017].

${ }^{24}$ Przez lata funkcjonowania biznesu środowisko skupione wokół tej dyscypliny wypracowało specyficzny żargon. Właściwe dla niego specjalistyczne pojęcia pojawią się w dalszych częściach artykułu 
zbędnych pozorów przepisowego sportu; ona jednak nikogo nie obchodzi ${ }^{25}$. Prawdziwa wolnoamerykanka, określana niesłusznie jako amatorska, rozgrywana jest w podmiejskich salach, gdzie publiczność spontanicznie przystaje na widowiskowy charakter walki, podobnie jak publiczność kinowa z przedmieścia ${ }^{26}$.

W najprostszym ujęciu pro wrestling to rodzaj interdyscyplinarnego widowiska o charakterze sportowym, łączący w sobie atletyczny charakter zapasów i sztuk walki z elementami teatru, kabaretu, wodewilu. Hybrydyczną specyfikę dyscypliny podkreśla wspomniany już termin rozrywka sportowa, w myśl którego walor zabawy postawiony jest na równi ze sportowymi wyczynami.

Sharon Mazer zalicza wrestling do grona sztuk performatywnych, klasyfikując go jako widowisko zawieszone pomiędzy kulturowymi kategoriami:

Profesjonalne zapasy są sportem, który nie jest - w dosłownym tego słowa znaczeniu - sportowy, [są też] teatralną rozrywką, która nie jest teatrem. Pokaz przemocy, który jest nie tyle rywalizacją, ile zrytualizowaną potyczką oponentów powtarzaną wielokrotnie z myślą o niebywale zaangażowanej publiczności. Barwne postacie i historie opowiadane zarówno w ringu, jak i w telewizyjnym przekazie, który ubiera pojedynki w kontekst, są zarazem archetypiczne, jak i współczesne, otwarte na bezpośrednią interpretację, a jednak w swej otwartości odporne na proste odczytanie przez pryzmat wartości kultury dominującej ${ }^{27}$.

Wraz z ekspansją zapasów profesjonalnych poza granice Stanów Zjednoczonych powstał również szereg nowych określeń wyróżniających poszczególne nurty. W krajach anglosaskich niezmiennie funkcjonuje nazwa professional wrestling (w skrócie: „pro wrestling”; samo określenie „wrestling” odnosi się bowiem do zapasów klasycznych, będących dyscypliną olimpijską). W przypadku odmiany meksykańskiej mówimy o lucha libre

25 Barthes pisze swój felieton w 1957 roku, na kilka dekad przed dynamicznym rozwojem dyscypliny.

${ }^{26}$ R. Barthes, Swiat wolnoamerykanki, [w:] idem, Mitologie, tłum. A. Dziadek, Warszawa 2008, s. 31; podkr. moje - J.B.

27 S. Mazer, op. cit., s. 3 (jeśli nie podano inaczej, tłumaczenia pochodzą od autorki artykułu). 
(„wolna walka”) i uprawiających ją luchadores (spolszczonych jako „luchadorzy"). W Japonii z kolei funkcjonuje nazwa puroresu, będąca w istocie transliteracją japońskiej wymowy, w skrócie zapisywanej „pro-wres”28. Potocznie w Polsce funkcjonuje bezpośrednie zapożyczenie z języka angielskiego - pokazy zapasów profesjonalnych (bez względu na nurt) określa się mianem wrestlingu lub pro wrestlingu, jednak członkowie społeczności fanowskiej posługują się wszystkimi wymienionymi powyżej określeniami w zależności od kontekstu wypowiedzi.

\subsection{ZASIĘG PRO WRESTLINGU - NAJWIĘKSZE OGNISKA I ORGANIZACJE}

Rynek pro wrestlingu (zwany także sceną) dzieli się na organizacje głównego nurtu (mainstream) oraz niezależne (indie). Za główne wyznaczniki przynależności do danej kategorii uważa się zasięg przekazu oraz umowę emisji treści w telewizji i/lub na internetowych platformach streamingowych $^{29}$. Przyjmuje się, że organizacje głównego nurtu kładą nacisk przede wszystkim na widowiskowość przedstawienia i jego oprawy, podczas gdy istotą pokazów niezależnych jest ukazanie atletycznej finezji performerów ${ }^{30}$.

Choć ogólne reguły rządzące przedstawieniem są uniwersalne ${ }^{31}$, warianty regionalne różnią się od siebie detalami wyznaczanymi przez odmienne konteksty kulturowe. Opisywane poniżej odmiany są dla swoich źródłowych

${ }^{28}$ Co ciekawe, w środowisku fanowskim mianem puroresu określa się jedynie azjatycką odmianę wrestlingu, podczas gdy w samej Japonii termin ten obejmuje dyscyplinę samą w sobie.

29 Ramy tej definicji są płynne, a sam podział - umowny. Przykładowo, szacowana wartość organizacji Ring Of Honor (powszechnie uznawanej za niezależną) przewyższa wartość zaliczanej do mainstreamu Impact Wrestling. Z kolei programy marki Lucha Underground (również niezależnej) dostępne są na międzynarodowej platformie Netflix, zapewniającej jej zasięg kilkukrotnie większy niż wcześniej wspomnianej Impact Wrestling.

30 To także nie jest ścisłą regułą, czego dowodzi chociażby należąca do WWE marka NXT promująca młodych zawodników z zachowaniem minimalistycznej oprawy fabularno-wizualnej.

31 O ogólnych regułach rządzących pro wrestlingiem piszę w części zatytułowanej Zasady gry. Próba ujęcia teoretycznego. 
obszarów właściwe, ale nie ekskluzywne; dzięki transnarodowej mobilności performerów charakterystyczne style obecne są na wszystkich kontynentach, a same nurty przenikają się.

\subsubsection{Stany Zjednoczone}

Amerykański wariant pro wrestlingu jest jednocześnie wariantem najszerzej rozpowszechnionym i najłatwiej dostępnym (w głównej mierze dzięki globalnemu statusowi największej organizacji - World Wrestling Entertainment, do 2002 roku znanej jako World Wrestling Federation). Elementem wyróżniającym tę odmianę jest większe niż w pozostałych kręgach przywiązanie do ciągłości narracji i budowy odmiennych charakterologicznie postaci (czasami kosztem właściwej akcji w ringu). Od samego performera istotniejsza jest odgrywana przez niego postać, a ważne walki - przynajmniej w organizacjach głównego nurtu - muszą być podparte rozwiniętą historią.

Do najważniejszych organizacji należą:

- World Wrestling Entertainment - największa federacja zapaśnicza na świecie. Jej kapitał zakładowy szacowany jest na trzysta trzydzieści miliardów dolarów ${ }^{32}$. Swoje audycje przetłumaczone na trzydzieści języków nadaje w stu czterdziestu pięciu krajach, osiągając zasięg trzynastu milionów widzów ${ }^{33}$. Wchodzi w skład konglomeratu medialnego zatrudniającego osiemset czterdzieści pracowników ${ }^{34}$ oprócz pokazów zapaśniczych majątek WWE obejmuje także między innymi studio filmowe WWE Studios i internetową platformę streamingową WWE Network;

- Impact Wrestling (znana wcześniej jako Total Nonstop Action Wrestling i Global Force Wrestling) - druga co do wielkości organizacja głównego nurtu, założona w 2002 roku przez braci Jerry’ego i Jeffa Jarrettów. Przez lata stanowiła mainstreamową enklawę feministycznego wrestlingu - podczas gdy konkurencja sprowadzała swoje performerki do roli ozdobnego przerywnika (ukierunkowując

32 http://corporate.wwe.com/documents/PressReleaseQ3201011.04.10 FINAL_001.pdf [dostęp: 18.03.2017].

33 Ibidem.

34 Ibidem. 
ich występy przede wszystkim na eksponowanie ich fizycznych atutów, na przykład przez pojedynki rozgrywające się wewnątrz basenu wypełnionego budyniem albo infantylne pillow fights - walki na poduszki) lub całkowicie pomijała ich udział w pokazach (w organizacji ROH aż do 2015 roku kobiety występowały sporadycznie), w ówczesnym TNA kobieca dywizja (określana mianem Knockouts) traktowana była na równi ze swoimi męskimi współpracownikami, mając możliwość udziału w walkach podwyższonego ryzyka, a nawet walkach wieczoru - co w zdominowanej przez mężczyzn dziedzinie wciąż jest niezwykle rzadkim odstępstwem od reguły;

- $\quad$ Ring of Honor - największa organizacja niezależna na amerykańskim rynku założona w 2002 roku przez Roba Feinsteina. Wyróżnia się tak zwanym Kodem Honoru (Code of Honor) - zespołem zasad gwarantujących pozory sportowości przedstawienia. Kod ten stanowi zarówno swoistą etykietę (wśród zasad znajdują się między innymi: kurtuazyjny uścisk dłoni przed rozpoczęciem pojedynku, poszanowanie nadrzędnej pozycji sędziego oraz zakaz zadawania ciosów poniżej pasa), jak i istotne narzędzie narracyjne, bowiem intencjonalne złamanie zasad Kodu przez jedną ze stron automatycznie ukazuje podział na bohaterów pozytywnych i negatywnych, bez potrzeby rozwiniętej podstawy fabularnej;

- Lucha Underground - jedna z najmłodszych organizacji zapaśniczych założona w 2014 roku. Wyróżnia się przede wszystkim formą prezentacji treści. W przeciwieństwie do konkurencyjnych organizacji, opierających swoją działalność na pokazach cotygodniowych (WWE, GFW) lub cyklicznych (ROH), Lucha Underground prowadzi narrację w zamkniętej formie serialu. Wątki fabularne zamykają się w obrębie liczby odcinków wchodzących w skład danej serii. Dotychczas zrealizowano trzy pełne sezony programu (w sumie liczące sobie dziewięćdziesiąt sześć odcinków).

Niezwykle zróżnicowana amerykańska scena niezależna wypełnia różne nisze preferencji społeczności fanów pro wrestlingu. Wśród tysięcy niedużych klubów znajdują się między innymi: organizacje kobiece (np. SHIMMER Women Athletes, Shine Wrestling lub Women Superstars Uncensored), komediowe (np. Chikara) lub specjalizujące się w pojedynkach podwyższonego 
ryzyka organizacje ultraviolent (np. Combat Zone Wrestling). Działalność klubów niezależnych zazwyczaj połączona jest $\mathrm{z}$ funkcjonowaniem szkółek treningowych. W przypadków najmniejszych klubów kursy dla adeptów nierzadko stanowią główne źródło utrzymania.

\subsubsection{Meksyk}

Początków lucha libre należy szukać już w drugiej połowie XIX wieku legenda głosi, że tradycję zapaśniczą przekazali przybywający do Meksyku w latach 60. XIX wieku francuscy imigranci ${ }^{35}$. Przez lata widowiskowe pojedynki pozostawały regionalną ciekawostką. W 1933 roku Salvador Lutteroth zakłada Empresa Mexicana de Lucha Libre ${ }^{36}$ - pierwszą zorganizowaną federację pro wrestlingu o zasięgu ogólnokrajowym ${ }^{37}$. Podobnie jak w przypadku amerykańskich territories, dynamiczny rozwój nowego medium - telewizji - znacząco wpłynął na popularność dyscypliny, a najsłynniejsi zawodnicy - luchadorzy - tacy jak El Santo („Swięty”) czy Mil Máscaras („Człowiek Tysiąca Masek”) zyskali status ikon popkultury ${ }^{38}$. Lucha libre do dziś uważane jest za najbardziej charakterystyczny element meksykańskiej kultury popularnej ${ }^{39}$.

Choreografia pojedynków lucha libre charakteryzuje się szczególną widowiskowością. Priorytetem nie jest realizm przedstawienia, a czysta przyjemność widza sycącego wzrok akrobatyczną finezją performansu. Stąd też luchadorzy lwią część walki spędzają w powietrzu, wyprowadzając wymyślne ciosy i kopnięcia, a lin otaczających ring używają jako katapult.

Najważniejszym elementem identyfikacji luchadora jest unikatowa dla każdej postaci maska (máscara). O ile w wariancie amerykańskim zwykle

35 The History Of Lucha Libre, https://web.archive.org/web/20120913065250/ http://www.bongo.net/papers/lucha.htm [dostęp: 21.03.2017]

${ }^{36}$ W skrócie: EMLL, dziś znaną jako CMLL - Consejo Mundial de Lucha Libre; obie nazwy funkcjonują wymiennie.

37 B. Racięski, Zamaskowani zapaśnicy na granicy światów. Lucha libre na ringu i w kinie jako przykład popkulturowego synkretyzmu, [w:] Synkretyzm nowego świata, red. P. Kalina, Kraków 2015, s. 88.

38 O fenomenie tych zawodników i nurcie filmów lucha - cine de lucha libre piszę w części zatytułowanej Pro wrestling w kulturze popularnej.

39 B. Racięski, op. cit., s. 87. 
sprowadzana jest ona do roli gadżetu, o tyle w Meksyku stanowi swego rodzaju świętość. Ze zwyczajem zakrywania twarzy, rzekomo wywodzącym się z rytualnych obrzędów Azteków ${ }^{40}$, wiąże się anonimowość performerów. Personalia i wizerunki zapaśników tradycyjnie objęte są ścisłą tajemnicą, co sprzyja skupieniu uwagi na odgrywanej postaci ${ }^{41}$. Jako autonomiczny składnik tożsamości luchadora maska ma nieocenioną wartość i stawiana jest na równi z tytułem mistrzowskim. Pojedynki typu máscara contra máscara, máscara contra cabellera i máscara contra campeonato, w których na szali znajdują się kolejno: dwie maski, maska i włosy oraz maska i tytuł mistrzowski, niezmiennie wzbudzają wielkie emocje. Odsłonięcie twarzy jest bowiem dla luchadora najwyższą hańbą - raz utracona maska przepada na zawsze, a upokorzony wojownik zmuszony jest zakończyć karierę lub walczyć z odsłoniętą twarzą.

Do największych organizacji lucha libre należą CMLL - Consejo Mundial de Lucha Libre (najstarsza działająca organizacja pro wrestlingu na świecie) i Lucha Libre AAA Worldwide.

\subsubsection{Japonia}

Japońscy zapaśnicy są najpotężniejszą klasą człowieka: bezmiernie tędzy i przyozdobieni bojowymi malunkami [...], budzą trwogę nawet wśród obserwatorów, nie mówiąc o przeciwniku, który spogląda na giganta pierwszy $\mathrm{raz}^{42}$.

Opisując japońskie zawody zapaśnicze, Anderson prawdopodobnie odnosi się do narodowego sportu Kraju Kwitnącej Wiśni - sumo. Jako najsłynniejszego zawodnika wskazuje jednak Matsudę Sorakichiego ${ }^{43}$, pioniera

40 Założenie maski z wizerunkiem danego zwierzęcia - tygrysa, orła czy jaguara - miało na celu przyswojenie charakterystycznych cech mistycznego patrona. Ozdobieni wizerunkami uczestnicy rytuału odbywali następnie pojedynek, który miał zapewnić przychylność sił natury. Ibidem, s. 89.

${ }^{41}$ Anonimowość luchadorów ma także wymiar praktyczny - często zdarza się bowiem, iż na przestrzeni lat w jedną postać wciela się kilku performerów.

${ }^{42}$ W. Anderson, op. cit., s. 49.

43 Błędnie zwanego „Matsadą” zarówno przez Andersona, jak i amerykańskich promotorów, z którymi współpracował. 
ruchu puroresu. Sorakichi - mistrz zapasów zarówno sumo, jak i catch po latach współpracy z amerykańskimi promotorami próbował przenieść kształtującą się dyscyplinę na grunt swojego rodzimego kraju, jednak jego starania były bezskuteczne.

Udało się to dopiero po 1945 roku. Japońskie społeczeństwo, wyniszczone tragedią II wojny światowej, potrzebowało sposobu na złagodzenie zbiorowej traumy. Sport miał zadziałać terapeutycznie, a w szczególności wrestling - ze względu na odgórnie ustalany charakter pojedynków organizatorzy mogli mieć pewność co do tego, że triumfalne zwycięstwo rodzimego herosa ${ }^{44}$ nad przybyszem z zewnątrz podniesie na duchu zgromadzonych widzów ${ }^{45}$.

Puroresu traktowane jest w Japonii jako pełnowartościowy sport. Odzwierciedla to pojęcie strong style lub shoot style, który zbliża pokazy puroresu do zawodów mieszanych sztuk walki ${ }^{46}$. Wyniki walk ustalone są z góry, jednak stosowane dźwignie i ciosy wymierzane bywają naprawdę.

Ze względu na silnie nacjonalistyczne początki dyscypliny (tuż po wojnie większość pojedynków odbywała się wedle schematu „dobry Japończyk kontra zły gaijin - cudzoziemiec") nie wykształcił się tu typowy dla anglosaskiego wariantu podział na dobre i złe postacie ${ }^{47}$. Sympatię widzów zdobywa się tu wysiłkiem i ciężką pracą włożoną w samodoskonalenie się i pielęgnację ducha walki (fighting spirit). Kluczowym elementem nie jest przesadnie rozbudowana fabuła, a czysta w swojej formie chęć bycia obiektywnie lepszym od swoich konkurentów. Głównym narzędziem narracyjnym jest $\mathrm{z}$ kolei walka sama w sobie ${ }^{48}$.

44 Rikidōzan, pionier i popularyzator wrestlingu w Japonii, zwany także „Ojcem Puroresu”, był tak naprawdę koreańskim imigrantem. Doświadczywszy dyskryminacji z powodu swojej narodowości, postanowił przyjąć japońsko brzmiące nazwisko - Mitsuhiro Momota. Do dziś Rikidōzan uważany jest w Japonii za bohatera narodowego i ikonę popkultury.

45 C. Charlton, Japan's National Korean Icon, [w:] idem, Lion's Pride: the Turbulent History of New Japan Pro Wrestling, self-published, 2015, s. 8.

${ }^{46}$ Wielu zawodników specjalizujących się w puroresu (m.in. Antonio Inoki i Shinsuke Nakamura) bierze udział także w walkach MMA.

47 C. Charlton, op. cit., s. 14.

48 Ibidem, s. 15. 
Do najważniejszych organizacji należą: New Japan Pro Wrestling (założona w 1972 roku przez ucznia Rikidōzana, Antonio Inokiego), All Japan Pro Wrestling oraz Pro Wrestling NOAH (nazwa nawiązuje do biblijnej Arki Noego). Prężnie działa także scena wrestlingu kobiecego określana mianem joshi ${ }^{49}$. Japońska liga performerek - choć podziwiana przez stosunkowo wąskie grono odbiorców - uznawana jest za najlepszą na świecie.

\subsubsection{Europa}

Europejska scena pro wrestlingu funkcjonuje niejako poza głównym nurtem. W przeciwieństwie do swoich północnoamerykańskich i dalekowschodnich odpowiedników, nie występuje tu żadna organizacja pretendująca do miana globalnej. Wręcz przeciwnie - całość działalności bazuje na setkach małych i średnich niezależnych klubów rozsianych po całym kontynencie ${ }^{50}$.

Europejski wrestling nie posiada tak wyrazistych cech dystynktywnych jak jego meksykański czy japoński odpowiednik, choć nie sposób nie zauważyć silnego wpływu zapasów catch - w języku niemieckim do dziś określenie to jest synonimiczne z profesjonalnym wrestlingiem i obecne w nazwach wielu klubów. Najwięcej organizacji zapaśniczych w Europie działa w Wielkiej Brytanii (w samej tylko Anglii funkcjonuje ich przeszło setka) oraz Niemczech.

\section{ZASADY GRY. PRÓBA UJĘCIA TEORETYCZNEGO}

\subsection{OGÓLNE REGUŁY}

Można zatem zrozumieć, że na pięć walk wolnoamerykanki mniej więcej jedna jest przepisowa. Trzeba pamiętać, że przepisowość jest tu rolą lub gatunkiem podobnie jak w teatrze: przepis wcale nie stanowi rzeczywistego przymusu, ale konwencjonalny pozór przepisowości. Faktycznie

${ }_{49}$ Reprezentowane m.in. przez organizacje Stardom i Ice Ribbon.

${ }^{50}$ Z tego względu konieczna jest współpraca poszczególnych szkółek i klubów. Przybierać ona może różne formy, np. swobodnego przepływu performerów, wspólnych treningów i kursów szkoleniowych, a także organizowania wspólnych pokazów (nie tylko urozmaica to sam performans, ale też pozwala rozłożyć koszty organizacji danego przedsięwzięcia, co wydaje się szczególnie istotne zwłaszcza w przypadku najmniejszych klubów). 
zatem walka przepisowa to nic innego, jak walka przesadnie ugrzeczniona ${ }^{51}$ : walczący bardzo się starają, bez właściwej starciu wściekłości potrafią panować nad swoimi namiętnościami, nie rzucają się zapamiętale na pokonanego, na polecenie przerywają walkę i pozdrawiają się wzajemnie na koniec każdego ostrzejszego epizodu, w którym przecież nie przestali być wobec siebie lojalni. Trzeba naturalnie zrozumieć, że wszystkie owe uprzejme działania są sygnalizowane publiczności poprzez najbardziej konwencjonalne gesty lojalności: uścisk dłoni, podniesienie rąk, ostentacyjne zaniechanie bezowocnego chwytu, który zagrażałby doskonałości walki ${ }^{52}$.

Mówi się, że zasady są po to, żeby je łamać. Twierdzenie to znakomicie ilustruje istotę uchwyconego przez Rolanda Barthes'a pozoru przepisowości wrestlingu. Jego charakterystyczną cechą jest bowiem n adużyci e; wprawny widz prędko zorientuje się, że każda reguła, każdy warunek wprowadzony ponad standardowy zestaw przepisów zostanie w pewnym momencie pojedynku - zgodnie ze skryptem - złamany.

\subsubsection{Typy pokazów}

Pokazy wrestlingu odbywają się w kilku podstawowych formach: na żywo $\mathrm{z}$ udziałem kamer (live broadcast), bez ich udziału (live event albo house show) lub jako nagrania telewizyjne w celu późniejszej emisji w telewizji, Internecie albo fizycznej dystrybucji (tapingi). Każda z tych metod różni się od pozostałych nie tylko warunkami realizacji, ale i funkcjami, jakie spełnia.

Live event czy house show to pokaz odbywający się na żywo wyłącznie dla zgromadzonej w budynku publiczności. Scenariusz jego przebiegu jest szczątkowy i ogranicza się do krótkich, najczęściej improwizowanych, przemówień oraz pojedynków, których jedynym celem jest zapewnienie rozrywki widzom. Pokazy te cechują się swobodną atmosferą i wysokim poziomem interaktywności - performerzy mogą bez ograniczeń kontaktować się z publicznością. Pojedynki pozbawione są kontekstu fabularnego, a ich wyniki często bywają losowe lub oparte na preferencjach lokalnej

${ }^{51}$ Najczęściej do takiej sytuacji dochodzi w przypadku pojedynku dwóch bohaterów pozytywnych - babyface'ów.

${ }_{52}$ R. Barthes, op. cit., s. 39; podkr. moje - J.B. 


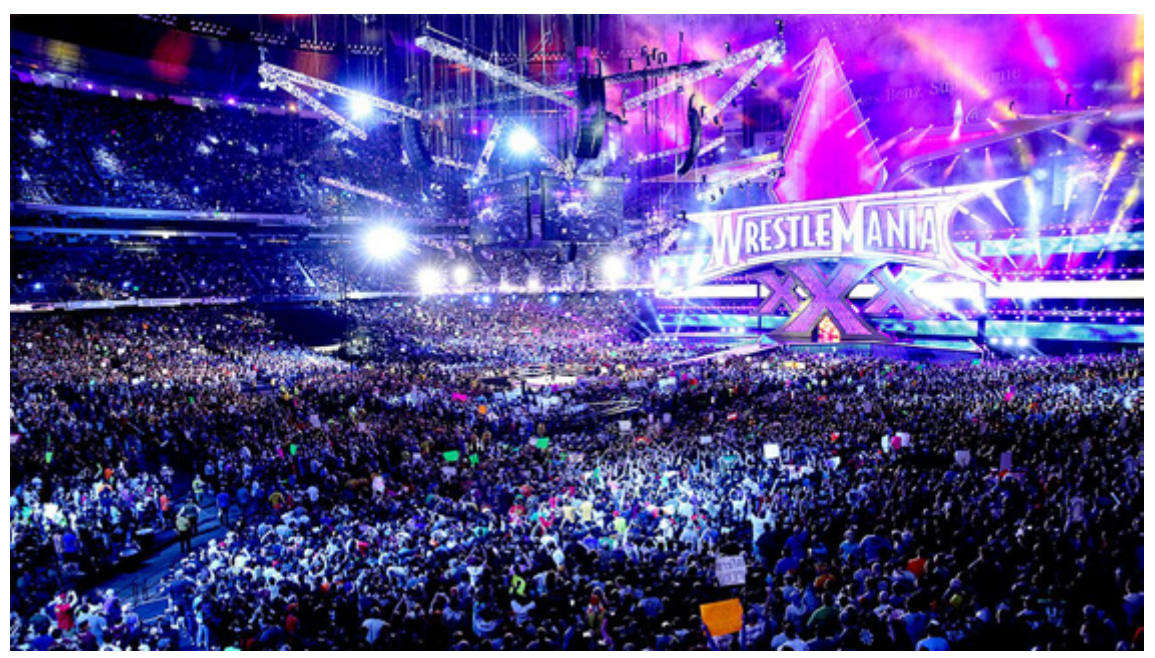

Il. 4. Wrestlemania jest największym pokazem w kalendarzu imprez WWE

widowni ${ }^{53}$. Dzięki położeniu nacisku na aspekt niezmąconych niczym zapasów pokazom na żywo najbliżej jest do Barthes'owskiego ideału „prawdziwej wolnoamerykanki" ${ }^{54}$.

Nagrania telewizyjne (na żywo bądź zarejestrowane w celu późniejszej emisji) służą nadaniu szerszego kontekstu pojedynkom ${ }^{55}$. Szczegółowy scenariusz (dotyczący zarówno przebiegu walk i ich wyników, jak i fabularyzowanych przerywników w formie skeczy, wywiadów, przemówień lub słownych potyczek pomiędzy performerami) nie pozostawia wiele miejsca na improwizację. Istotą tego typu produkcji jest stworzenie spójnego przekazu dla masowego widza, dlatego też - niczym telenowela - posługują się one prostymi chwytami narracyjnymi, uniwersalnymi stereotypami i repetycjami, porzucając zawiłe wątki na rzecz maksymalnej klarowności.

Rywalizacje i fabuły zarysowane podczas nagrań tak zwanych tygodniówek najczęściej prowadzą do istotniejszych pojedynków, które odbywają

53 Tradycyjnie podczas live events swoje walki wygrywają tak zwani hometown heroes - performerzy pochodzący z miasta lub stanu, w którym odbywa się dany pokaz.

54 R. Barthes, op. cit., s. 31.

55 S. Mazer, op. cit., s. 3. 
się w ramach cyklicznych pokazów specjalnych, zwyczajowo zwanych - od formy transmisji - Pay-Per-View lub iPay-Per-View ${ }^{56}$. Treści prezentowane podczas tego typu pokazów to najczęściej momenty kluczowe lub kulminacyjne dla fabuł poszczególnych rywalizacji, a wydarzenia z największych lub najstarszych gal (takich jak „Wielka Czwórka”: Wrestlemania, SummerSlam, Survivor Series i Royal Rumble w przypadku WWE, a także Slammiversary w przypadku Impact Wrestling) uważane są za szczególnie istotne ${ }^{57}$.

\subsubsection{Zasady walki}

Pozory przepisowości wrestlingu przejawiają się w zestawie podstawowych zasad mających na celu nadanie widowisku znamion sportowości i zamaskowanie fikcyjnego charakteru prezentowanych starć. Zwycięzca ustalany jest bowiem przez promotora najczęściej jeszcze zanim zacznie się pokaz lub - rzadziej - już w jego trakcie.

W walce bierze udział przynajmniej dwóch zawodników i sędzia. Najczęściej zestawia się ze sobą postać pozytywną (zwaną w branżowym żargonie babyface'em lub face'em ${ }^{58}$ ) i postać negatywną (heela ${ }^{59}$ ), choć i od tej reguły zdarzają się wyjątki. Zwyciężyć w podstawowym wariancie pojedynku można na jeden z kilku sposobów:

- $\quad$ przypięcie (pin lub pinfall) - to najczęściej wykorzystywane rozwiązanie. Następuje wówczas, gdy łopatki jednego z zawodników dotykają maty na tyle długo, by sędzia zdążył trzykrotnie uderzyć w nią dłonią. Przypięcie można przerwać, odrywając łopatkę od maty (kickout) lub dotykając liny otaczającej ring (rope break);

- $\quad$ poddanie się (submission) - następuje w momencie, gdy przeciwnik utrzymywany w zapaśniczej dźwigni poddaje się z własnej woli. Może to zostać zasygnalizowane ustnie lub przez wielokrotne uderzenie

56 Pokazy te nie są ogólnodostępne. Wgląd do nich można uzyskać za dodatkową opłatą u dystrybutorów kablowych, cyfrowych (PPV) lub internetowych (iPPV).

57 W czasach sprzed regularnych audycji telewizyjnych szczególnie ważne wydarzenia, takie jak pojedynki o tytuły mistrzowskie, zarezerwowane były właśnie dla pokazów „Wielkiej Czwórki”.

${ }_{58}$ S. Mazer, op. cit., s. 27.

59 Ibidem. 
dłonią w matę. Podobnie jak w przypadku przypięcia, dotknięcie liny wiąże się z koniecznością przerwania dźwigni;

- $\quad$ wyliczenie (countout) - następuje wówczas, gdy co najmniej jeden z performerów znajduje się poza ringiem i nie zdąży do niego wrócić w ustalonym wcześniej czasie (w wariancie amerykańskim jest to wyliczenie do dziesięciu, natomiast w lucha libre i puroresu sędzia musi doliczyć do dwudziestu);

- $\quad$ nokaut (knockout, KO) - ogłaszany jest, gdy utrzymywany w dźwigni (np. duszeniu) zawodnik „zemdleje” (nie zareaguje na nawoływania sędziego) lub gdy zawodnikowi po przyjęciu ciosu nie uda się podnieść $\mathrm{z}$ maty w wyznaczonym czasie (podobnie jak w przypadku wyliczenia, w zależności od wariantu jest to doliczenie przez sędziego do dziesięciu lub dwudziestu);

- dyskwalifikacja - następuje w momencie, gdy jeden z zawodników złamie jedną z podstawowych zasad pojedynku, np. użyje zabronionego przedmiotu lub manewru (chociażby ataku poniżej pasa) albo nie przerwie dźwigni po rope break’u. Ogłaszana jest także w przypadku ingerencji osoby niebiorącej udziału w pojedynku (np. menedżera).

Sędzia ma także prawo pozostawić walkę bez rozstrzygnięcia (no contest) w przypadku remisu (na przykład wtedy, gdy w trakcie przypięcia łopatki obojga zawodników dotykają maty, albo podczas podwójnego nokautu), kontuzji jednego z zawodników lub podwójnej dyskwalifikacji. Jeśli pojedynek ograniczony jest konkretnym limitem czasowym, remis ogłaszany jest także w momencie jego upłynięcia.

Istotą walki nie jest jednak jej wynik. Jak zauważa Roland Barthes, podstawowym celem zawodnika „nie jest zwycięstwo, ale dokładne wykonanie gestów, jakich się od niego oczekuje”60. Podobnie pisze Sharon Mazer: „na szali nie leży wygrana lub przegrana per se. Jest to raczej sposób, w jaki ta gra jest rozgrywana"61. To, jak kończy się dany pojedynek, jest przy tym kluczowe z punktu widzenia narracji. Poddanie przeciwnika lub nokaut konstytuuje fizyczną dominację zwycięzcy; spowodowanie dyskwalifikacji

60 R. Barthes, op. cit., s. 32.

${ }^{61}$ S. Mazer, op. cit., s. 8. 
pogłębia łajdactwo czarnego charakteru (może też sugerować desperację); remis natomiast sugeruje równość pomiędzy performerami.

\subsubsection{Rodzaje pojedynków}

Starcie dwóch zawodników na standardowych zasadach (singles match lub normal match) to tylko jedna $\mathrm{z}$ wielu możliwych wariacji, jakie występują w pro wrestlingu. Nowe rodzaje walk tworzy się przez modyfikację jednej lub kilku podstawowych zasad. Promotorzy z całego świata wymyślili przynajmniej kilkadziesiąt różnych wariacji standardowego pojedynku (gimmick match lub concept match), można je jednak podzielić na kilka większych kategorii pod kątem typu zastosowanej modyfikacji:

- $\quad$ zwiększenie liczby uczestników - najprostszym sposobem na wprowadzenie różnorodności do karty walki jest rozszerzenie liczby zapaśników biorących w niej udział. Pojedynki wieloosobowe mogą odbywać się do pierwszego przypięcia lub z warunkiem eliminacji kolejnych przeciwników (elimination match). Innym wariantem pojedynku wieloosobowego może być pojedynek drużynowy z przewagą liczebną jednej ze stron (handicap match) lub maraton (gauntlet match), w którym jeden zawodnik zmuszony jest odbyć serię następujących po sobie pojedynków, z których każdy kolejny rozpoczyna się w momencie zakończenia poprzedniego. Ciekawym przypadkiem jest także pojedynek typu battle royal. Określona liczba zawodników rozpoczyna go wewnątrz ringu, starając się wyrzucić z niego pozostałych uczestników walki;

- zamknięcie lub uwolnienie przestrzeni walki - standardowy pojedynek domyślnie odbywa się w ograniczonej przestrzeni ringu, który jednak zawodnicy mogą dowolnie opuszczać (pod warunkiem, że zdążą doń wrócić w wyznaczonym czasie). Aby zróżnicować przedstawienie, można ową przestrzeń zamknąć - na przykład w formie klatki (wariantów pojedynków w klatce jest przynajmniej kilkanaście) lub innych zawodników otaczających ring, tak zwanych drwali lub drwalek (lumberjack lub - w przypadku kobiet - lumberjill match). Można także tę przestrzeń otworzyć, eliminując konieczność wyliczenia przez sędziego (no countout match). W pojedynkach typu falls count anywhere przypięcie lub poddanie się może nastąpić 


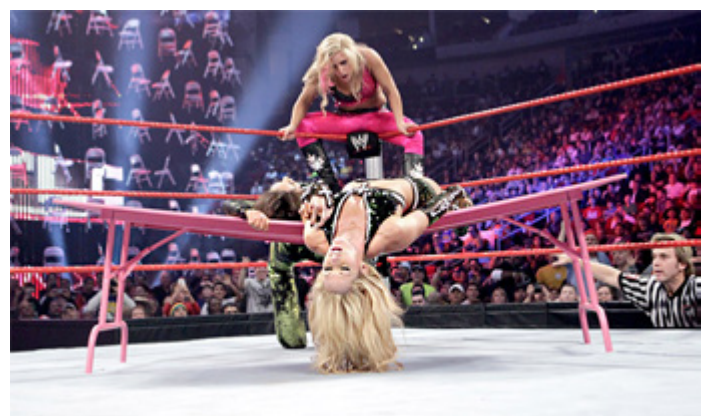

Il. 5. Tables match. Zawodniczka przygotowuje się do skoku kończącego pojedynek

w dowolnym miejscu, w ekstremalnych przypadkach nawet poza budynkiem, w którym odbywa się pokaz;

- $\quad$ usunięcie jednego lub kilku ograniczeń - w tym przypadku najczęściej wykorzystywaną modyfikacją jest zawieszenie zasady dyskwalifikacji (no DQ match) lub umożliwienie korzystania z konkretnego przedmiotu, zabronionego w standardowym pojedynku (nazwy takich wariacji tworzone są od nazwy przedmiotów, np. chairs matches lub tables matches w przypadku pojedynków dopuszczających użycie krzeseł lub stołów). W niektórych przypadkach zmianie ulega także warunek, który należy spełnić, by dany pojedynek zwyciężyć. Przykładowo, walkę z drabinami (ladder match) wygrywa ten, komu uda się ściągnąć nagrodę zawieszoną nad ringiem² (najczęściej jest to pas mistrzowski), z kolei tables match przegrywa ten, kto pierwszy złamie stół swoim ciałem ${ }^{63}$ wskutek popełnionego błędu lub intencjonalnie zadanego ciosu;

- $\quad$ połączenie kilku modyfikacji: najbardziej rozpoznawalnym przykładem hybrydy przepisów jest pojedynek typu elimination chamber. Odbywa się on w klatce, w którą wbudowane są cztery komory ze szkła akrylowego z zamkniętymi w nich zawodnikami. Bierze

${ }^{62}$ Zasada ta dotyczy także modyfikacji pojedynku z drabinami dopuszczającej dodatkowo użycie krzeseł i stołów - TLC: tables, ladders and chairs match.

${ }^{63}$ Stoły wykorzystywane w tego typu pojedynkach są wcześniej przygotowywane przez rekwizytorów, tak by zminimalizować ryzyko kontuzji zawodników. 


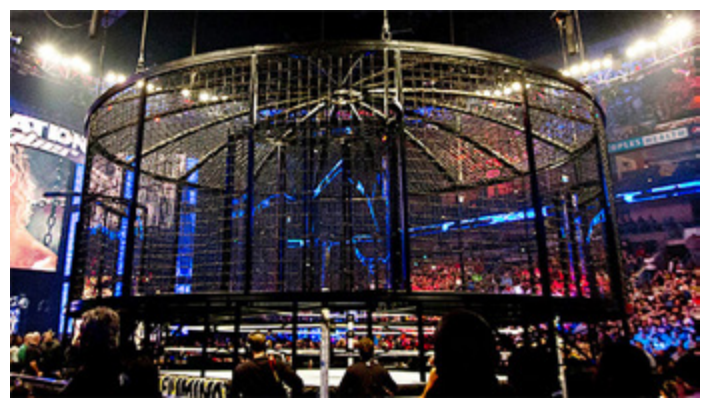

Il. 6. Klatka Elimination chamber

w nim udział sześć osób - w ringu rozpoczynają pojedynek dwie, kolejne wpuszczane są w ustalonej wcześniej (choć owianej tajemnicą) kolejności co około pięć minut. Przypięcie lub poddanie się równe jest eliminacji danego zawodnika. Nie obowiązuje zasada dyskwalifikacji.

Dużą popularnością, zwłaszcza w Meksyku, cieszą się pojedynki drużynowe (tag team match). Biorą w nich udział minimum dwie (najczęściej dwuosobowe ${ }^{64}$ ) drużyny. Mogą one odbywać się w wariancie podstawowym lub w jednej z wielu modyfikacji (z reguły pokrywających się z wymienionymi wyżej gimmick matches).

Szczególnym wariantem pojedynku drużynowego jest skonstruowane w CMLL torneo cibernetico - w pojedynku biorą udział dwie drużyny o liczebności do ośmiu członków. W starciu tym obowiązuje określony porządek, w jakim zawodnicy mogą wchodzić do ringu i eliminować przeciwników ${ }^{65}$. Jeśli po eliminacji wszystkich członków przeciwnej drużyny pozostanie dwóch lub więcej członków drużyny wygranej, muszą oni zmierzyć się ze sobą w celu wyłonienia definitywnego zwycięzcy.

\subsubsection{Stypulacje}

Stypulacja oznacza specjalne warunki, które ograniczają zawodników w trakcie trwania walki i wyznaczają potencjalną nagrodę dla zwycięzcy

${ }^{64}$ W lucha libre szczególną estymą cieszą się pojedynki drużyn trzyosobowych.

${ }_{65}$ Eliminacja następuje w momencie przypięcia, poddania się, wyliczenia lub dyskwalifikacji. 
lub karę dla przegranego. W wariancie amerykańskim warunki te często wykorzystywane są jako zabieg narracyjny, sygnalizujący konflikt pomiędzy zawodnikiem a jego przełożonym ${ }^{66}$. Wówczas ustalona stypulacja jest przejawem niechęci szefa wobec podwładnego i ma na celu utrudnienie mu pracy. Stypulacją tą może być na przykład utrata tytułu mistrzowskiego w wypadku dyskwalifikacji ${ }^{67}$, fizyczne utrudnienie walki (np. przez unieruchomienie jednej z kończyn) lub zakaz używania konkretnej akcji (najczęściej akcji kończącej - finishera).

Innym warunkiem może być konieczność opuszczenia organizacji w przypadku przegranej (tak zwany loser leaves town match - często wykorzystywany w celu fabularnego usprawiedliwienia wydarzeń zakulisowych, takich jak chociażby nieprzedłużenie kontraktu zawodnika z organizacją, lub retirement match - w przypadku chęci zakończenia kariery przez danego performera). Szczególnym typem stypulacji jest pojedynek typu winner takes all („zwycięzca bierze wszystko”), w przypadku którego obie strony (wariant ten ma zastosowanie także w pojedynkach drużynowych) posiadają szczególne wyróżnienia - najczęściej pasy mistrzowskie. Zwycięska strona otrzymuje oba wyróżnienia, podczas gdy przegrany odchodzi z pustymi rękami ${ }^{68}$.

Warunki te nie są jednak specjalizacją wyłącznie amerykańskich organizacji. Meksykańskie lucha libre słynie bowiem z pojedynków, w których na szali znajdują się włosy lub maska zawodnika. Wówczas poza standardowym zestawem przepisów obowiązuje dodatkowe zastrzeżenie - luchador, który przegra walkę, zmuszony jest ogolić głowę lub odsłonić twarz. Utrata maski jest w lucha libre ostateczna. Z kolei w wariancie puroresu, ze względu na przywiązanie do sportowego aspektu przedstawienia, stypulacje, podobnie jak gimmick matches, w zasadzie nie występują.

${ }^{66} \mathrm{O}$ archetypie Złego Szefa więcej piszę w rozdziale trzecim zatytułowanym Stereotypy.

${ }^{67}$ Dzięki zasadzie champion's advantage mistrz nie traci bowiem tytułu, jeśli pojedynek zakończy się dyskwalifikacją lub remisem.

${ }_{68}$ Konwencję tej wykorzystuje się zwykle na okoliczność unifikacji (połączenia) różnych mistrzostw, na przykład w sytuacji wykupienia jednej organizacji przez inną. 


\subsubsection{Rola promotora}

Promotor jest najważniejszą osobą każdej organizacji pro wrestlingu. Może, choć nie musi, być jej właścicielem ${ }^{69}$, może być także aktywnym zawodowo performerem ${ }^{70}$. Promotor kontroluje każdy element pokazu - to on zatrudnia i zwalnia zawodników, podejmuje decyzje biznesowe, dba o wizerunek organizacji, a także ustala skład pojedynków i ich kolejność w karcie ${ }^{71}$.

Promotor rozdaje karty, decydując o tym, kto zasługuje na wygraną, kogo należy promować (w zapaśniczym żargonie dobrą passę określa się jako push), a kto i na jakich zasadach powinien ustąpić innym zawodni$\mathrm{kom}^{72}$. W przypadku większych federacji nadzoruje i akceptuje bądź odrzuca scenariusze przygotowane przez zespół scenarzystów. Do promotora należy również ostatnie słowo w kwestii kreacji postaci, w jakie wcielają się zawodnicy, a jego rolę można porównać do obowiązków zarówno reżysera, jak i producenta przedstawienia.

\subsubsection{Rola sędziego}

Nie mniej ważnym elementem przedstawienia jest sędzia. Wbrew pozorom i potocznej intuicji jego rola nie polega jednak na egzekwowaniu przepisów (te są bowiem czysto umowne, a ich przestrzeganie bądź łamanie nie ma żadnego wpływu na ustalony wcześniej wynik pojedynku). Sędzia, tak jak zawodnicy, jest aktorem biorącym czynny udział w przedstawieniu zwykle w sposób transparentny i nieinwazyjny. Każda jego interwencja w przebieg pojedynku jest wcześniej zapisana w scenariuszu. W znacznej części przypadków ingerencja ta polega, paradoksalnie, na tworzeniu okazji

${ }^{69}$ Do takich przypadków należała chociażby organizacja WCW, której właścicielem był magnat medialny Ted Turner. Funkcję promotorów pełnili zatrudnieni przez niego producent Eric Bischoff i scenarzysta Vince Russo.

70 Do sytuacji takich dochodzi przede wszystkim na scenie niezależnej, gdzie promotor jest jednocześnie zawodnikiem (jak chociażby Mike Quackenbush, właściciel organizacji Chikara, czy „Sweet” Saraya Knight, założycielka kilku promocji na terenie Wielkiej Brytanii), komentatorem, a czasem także trenerem - jeśli z klubem związane są także szkółki dla młodych adeptów.

${ }^{71}$ S. Mazer, op. cit., s. 25.

72 Ibidem. 
do naruszania zasad ${ }^{73}$, czy to przez rzekomą nieuwagę, czy tė̇ chwilową niedyspozycję.

Sędzia jest także pośrednim animatorem pojedynku (w znacznej mierze improwizowanego przez zawodników ${ }^{74}$ ), swoistym łącznikiem między zawodnikami a promotorem lub - w przypadku większych organizacji - całą drużyną producentów. Dzięki specjalnej słuchawce znajduje się on w ciągłym kontakcie z przebywającym na zapleczu bądź w wozie transmisyjnym promotorem, będącym faktycznym reżyserem przedstawienia. Wydawane komunikaty przekazuje on zawodnikom zarówno bezpośrednio (choć, oczywiście, skrzętnie ukrywając to przed okiem widza), jak i przez ustalone wcześniej skonwencjonalizowane gesty i znaki niewerbalne.

\subsubsection{Rola menedżera}

Postać menedżera wprowadzana jest w celu wypromowania młodych lub mniej popularnych postaci. Bardzo często w tej roli obsadza się weteranów branży lub performerów charyzmatycznych, doświadczonych i szanowanych zarówno przez fanów, jak i współpracowników. Pełni on stanowisko rzecznika (w celu zamaskowania słabości swojego „klienta”) i swoistego mentora - zarówno przed publicznością, jak i za kulisami. Menedżer pomaga także swojemu podopiecznemu w walce - na przykład odwracając uwagę sędziego lub rozpraszając przeciwnika w odpowiednim momencie. Może także mieć wpływ na zakulisową politykę organizacji.

\subsection{STRUKTURA NARRACYJNA I KAYFABE}

\subsubsection{Kim jest zawodnik?}

Przypadkowi odbiorcy często posądzają zawodników o oszustwo, a sam wrestling nazywają sportem udawanym, fałszywym. Jednakże już Roland Barthes zauważał, że wolnoamerykanka nie jest sportem, a zapaśnikowi

73 Zazwyczaj z okazji tej korzysta zawodnik odgrywający rolę szwarccharakteru, choć nie jest to regułą.

${ }^{74}$ Przed rozpoczęciem pojedynku ustalane są zwykle tylko spoty (kombinacje ciosów i akcji) kluczowe dla dramaturgii przedstawienia (w tym sekwencja zamykająca pojedynek) lub fabuły rywalizacji, tudzież akcje szczególnie widowiskowe bądź niebezpieczne. Resztę walki zawodnicy konstruują spontanicznie, nieustannie komunikując się ze sobą. 
w trakcie pojedynku bliżej jest do aktora antycznego teatru: „doskonale naginającego spontaniczne epizody walki do tego obrazu, który publiczność wytwarza sobie z motywów własnej mitologii"75. Z kolei Sharon Mazer stanowczo podkreśla atletyczną bazę wrestlingu, nie pomijając jednakże wagi aktorskiego rzemiosła i widowiskowej oprawy:

Barwne kostiumy i rekwizyty, fantazyjne układy i pozy, skandalizująca retoryka, fabuły przeplatające operę mydlaną z karnawałem i nieustanny marketing - wszystko to zbliża profesjonalne zapasy raczej do teatralnego spektaklu telewizyjnego aniżeli atletycznych zawodów. Jednakże, mimo iż zapaśnicy odgrywają role, przywdziewają kostiumy i rekwizyty, rzucają ustalone wcześniej wyzwania, mimo że ich zwycięstwo lub porażka zależy nie od rozgrywki, lecz decyzji promotora, nie są aktorami per se. W rzeczywistości są oni niekłamanie silnymi, ponadprzeciętnie wprawnymi atletami, których występy wykraczają poza potoczne pojmowanie tego, co „prawdziwe”, a co „fałszywe"76.

Można więc przyjąć, że zapaśnik jest performerem łączącym umiejętności aktorskie, charyzmę oratora, zwinność gimnastyka, a także wytrzymałość oraz siłę olimpijskich atletów.

\subsubsection{Konstrukcja postaci scenicznej}

We wrestlingu można wyróżnić trzy podstawowe typy postaci: pozytywną (wspomnianego już babyface’a lub face'a), negatywną - heela (przez Rolanda Barthes’a określonego jako „łajdak”77), oraz pośrednią - tweenera. Charakter granej przez zawodnika postaci wytycza - zależnie od aktualnych potrzeb promotor, jednak o sposobie wykonania (unikatowych gestach, powiedzeniach, rekwizytach i zachowaniach) decyduje najczęściej sam zawodnik ${ }^{78}$.

75 R. Barthes, op. cit., s. 42.

${ }^{76}$ S. Mazer, op. cit., s. 19.

77 R. Barthes, op. cit., s. 33.

78 Ma to szczególne znaczenie zwłaszcza w przypadku sceny niezależnej, gdzie poszczególni zawodnicy występują na pokazach różnych organizacji. W federacjach głównego nurtu zmiany wizerunku zwykle wymagają konsultacji z promotorem, wiąże się to bowiem z koniecznością zastrzeżenia unikatowych znaków towarowych. 
Il. 7. „Chwalebny” Bobby Roode wykonuje gest typowy dla zarozumiałego, dumnego heela

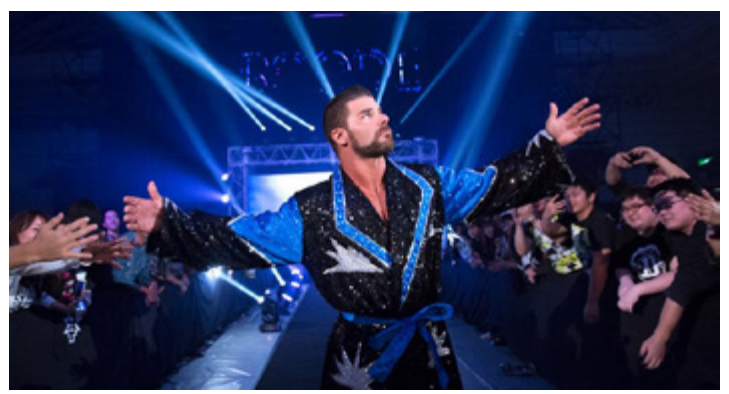

Jak zauważa Sharon Mazer, sam sposób, $\mathrm{w}$ jaki performer wchodzi do ringu (entrance), jest istotny z punktu widzenia narracji, definiuje bowiem nastawienie postaci i jej związek ze zgromadzoną na widowni publicznością ${ }^{79}$. Babyface entuzjastycznie nawiązuje interakcje $\mathrm{z}$ siedzącymi w pierwszych rzędach widzami, przybija „piątki” i zachęca do aktywnego, głośnego dopingu. Heel z kolei będzie zmierzał w stronę ringu niewzruszony i dumny lub prowokował buczenie w inny sposób.

Postacie te zachowują się inaczej także po rozpoczęciu pojedynku. Babyface'owie respektują nadrzędną pozycję sędziego, przestrzegają ustalonych zasad i ograniczeń narzuconych przez stypulację lub rodzaj walki. Swoje poczynania wewnątrz „kwadratowego pierścienia” ${ }^{80}$ dostosowują do oczekiwań publiczności, wykorzystując widowiskową choreografię i wykonując charakterystyczne gesty. Postępowanie heela jest zgoła odwrotne za nic ma sobie zasady (które nagina lub łamie przy każdej sposobności, stąd dawniej określany był w żargonie mianem rulebreaker - „łamiący zasady”) i nawoływania sędziego, dopuszcza się także użycia ciosów i taktyk zabronionych.

Charakter postaci może być manifestowany wizualnie, choćby przez paletę kolorystyczną ubioru performerów. Ma to szczególne znaczenie zwłaszcza w lucha libre (a także w przypadku zamaskowanych zapaśników spoza Meksyku) - ze względu na ograniczoną mimikę twarzy rodzaj kostiumu wysuwa się bowiem na pierwszy plan. Przyjmuje się, że bohaterowie (técnicos) wybierają barwy jasne, wiążące się z pozytywnymi konotacjami, natomiast antagoniści (rudos) ubierają się w ciemne barwy, a ich maski stylizowane są na wizerunki potworów, drapieżników lub demonów.

79 S. Mazer, op. cit., s. 30.

80 Ang. squared circle. W zapaśniczym żargonie mianem tym określa się ring. 
Określony charakter odgrywanej roli nie jest przy tym dany raz na zawsze. Postacie z czasem ewoluują, a ich cele, motywacje i strategie ulegają zmianie. Przemiana postaci nazywana jest w zapaśniczym żargonie „turnem” i występuje w dwóch odmianach: face

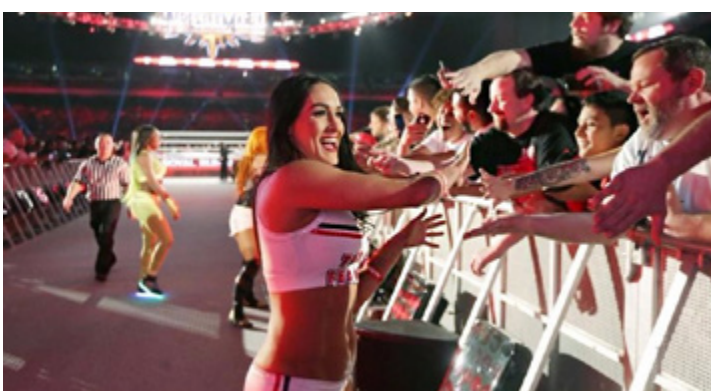

Il. 8. Babyface Nikki Bella pozdrawia fanów turn, jeśli szwarccharakter wraca na ścieżkę moralności, lub heel turn, jeśli to pozytywny bohater zaczyna łamać zasady. Turn może odbyć się nagle, bez wcześniejszych zapowiedzi (wówczas priorytetem jest zaskoczenie odbiorcy i podtrzymanie iluzji nieprzewidywalności), może być także poprzedzony (bardziej lub mniej subtelnymi) symptomami i gestami, które zwiastują wewnętrzną przemianę postaci, wpisując się w nieustannie tworzoną narrację.

Warto przy tym zaznaczyć, że wszelkie gesty i taktyki muszą być proste, żeby mogły być powszechnie zrozumiane. Przepisowa gra, jaką prowadzi babyface, przejawia się w gestach na wskroś konwencjonalnych, takich jak uścisk dłoni czy ostentacyjne uniesienie rąk sygnalizujące czystość inten$\mathrm{cji}^{81}$. Oszustwa, jakich dopuszcza się heel, zawsze uchwycone są przez celne oko kamery: niedozwolony przedmiot podsunięty przez menedżera lub przemycony przez samego zawodnika niemal zawsze pojawi się jako detal na telebimie, a intencjonalne pogwałcenie zasad zostaje dostrzeżone przez wszystkich z wyjątkiem sędziego. Znak jest bowiem w pro wrestlingu „absolutnie przezroczysty" "2, a narracyjne niuanse i wieloznaczności porzuca się na rzecz maksymalnej czytelności. Jak podsumowuje Roland Barthes:

W wolnoamerykance wszystko jest zawsze kompletne, nie ma tu żadnego symbolu, żadnej aluzji, wszystkie dane są wyczerpujące; gest, który nie

81 R. Barthes, op. cit., s. 39.

82 Ibidem, s. 33. 
pozostawia niczego w cieniu, odcina wszystkie pasożytnicze sensy i ceremonialnie, ze szczerością Natury, przedstawia publiczności czyste i pełne znaczenie ${ }^{83}$.

\subsubsection{Kayfabe}

Kluczowym dla zrozumienia istoty pro wrestlingu jest pojęcie kayfabe ${ }^{84}$. Mianem tym określa się konwencję dotyczącą wszystkich aspektów performansu, swoistą umowę między zawodnikiem a odbiorcą. Zawodnicy przekazują dane elementy skryptu jako wydarzenia autentyczne - stwarzają pozory, jakoby zaciekli rywale naprawdę się nienawidzili, rośli mężczyźni naprawdę mieli nadludzką siłę, „dobrzy” bohaterowie naprawdę kierowali się w życiu kompasem moralnym, a źli z kolei naprawdę pozbawieni byli wszelkich skrupułów. Odbiorcy natomiast, choć (zwykle) świadomi predeterminowanego charakteru widowiska ${ }^{85}$, akceptują jego fikcyjność i odczytują je nie tak, jak odczytaliby prawdziwą walkę bokserską, a raczej jak film o niej opowiadający. Kayfabe może być zatem rozumiany jako specyficzna mitologia środowiska związanego z wrestlingiem.

Zakres elementów podlegających tej konwencji zmieniał się na przestrzeni dekad. Aż do lat 90. XX wieku obejmował on nie tylko przedstawienie odbywające się w ringu, ale i owiany mgłą tajemnicy proces jego tworzenia za kulisami. Owa konwencja zakładała także utożsamienie kreowanych postaci z wcielającymi się w nie performerami, w związku z czym byli oni zobowiązani grać nie tylko w ringu, ale i poza nim, na przykład udzielając wywiadów, pokazując się publicznie (niemożliwe było, aby zawodnicy wcielający się w postacie pozytywne byli widywani ze swoimi ringowymi antagonistami) lub spotykając się z fanami dyscypliny (chociażby odmawiając złożenia autografu lub zrobienia pamiątkowego zdjęcia w przypadku czarnych charakterów). W przypadku luchadorów konwencja kayfabe wymagała noszenia maski także poza ringiem, na przykład w trakcie publicznych wystąpień (tajemnicą był nie tylko wizerunek atlety, ale i jego personalia).

83 Ibidem, s. 41.

${ }^{84}$ Słowo to nie ma polskiego odpowiednika.

${ }^{85}$ Jak zauważa Sharon Mazer (op. cit., s. 6), odbiorcy wrestlingu bezustannie uczestniczą w procesie wtajemniczania. Promotorzy natomiast bez przerwy dokładają starań ku temu, by prezentowane treści wydawały się nieprzewidywalne i nieszablonowe. 
Tym sposobem widzowie $\mathrm{w}$ pełni zanurzeni byli w historii opowiadanej na pokazach i reagowali na dane postacie tak, jak życzył sobie tego promotor. Bohaterom pozytywnym łatwiej było utrzymać status uwielbianych herosów, z kolei czarne charaktery zawsze mogły liczyć na to, że zostaną „wybuczane” ${ }^{\text {" }}$. Miejskie legendy krążące w środowisku fanowskim jedynie wzmacniały przekaz, pozwalając ugruntować charakter danego performera (utożsamianego z odgrywaną przezeń postacią).

Obecnie sytuacje takie zdarzają się sporadycznie, a kayfabe ogranicza się zazwyczaj do czasu trwania pokazów ${ }^{87}$. Przyczyniło się do tego wiele czynników, wśród których za najważniejsze należy uznać dynamiczny rozwój Internetu i mediów społecznościowych. Zawodnicy sami decydują, czy na swoich profilach prezentować się zgodnie z konwencją - jako postać, czy zrezygnować z niej. Niektórzy decydują się poinformować o tym wprost, na przykład Adam Scherr, wcielający się w postać Brauna Strowmana na pokazach WWE, w opisie swojego konta w serwisie Instagram zastrzega: „to moja prywatna strona, nie przedstawia postaci, którą gram w TV"88. Z kolei Chris Jericho przyznaje, że zarówno jego wpisy w mediach społecznościowych, jak i zachowanie podczas wywiadów lub interakcji z przypadkowo spotkanymi fanami zawsze odzwierciedlają charakter postaci, w którą akurat się wciela, co kilkukrotnie doprowadziło do nieprzyjemnych incydentów ${ }^{89}$.

${ }^{86}$ Nie oznaczało to wcale, że swoją pracę wykonywały one źle - wręcz przeciwnie. Głośne buczenie to dla osoby wcielającej się w szwarccharakter najwyższy komplement, wszak jej zadaniem jest właśnie sprawienie, by publiczność szczerze kochała tę postać nienawidzić.

87 Za datę symbolicznej „śmierci” konwencji kayfabe uznaje się 15 grudnia 1997 roku - początek Ery Attitude. W krótkim oświadczeniu wyemitowanym przed rozpoczęciem audycji Raw prezes WWF, Vince McMahon, zapowiedział świadomą zmianę charakteru prezentowanych treści, by dopasować je do oczekiwań widzów. W ten sposób McMahon nie tylko przełamał tak zwaną czwartą ścianę, ale i z premedytacją zdradził elementy struktury narracyjnej konstytuujące fikcyjność przedstawienia, od lat będące pilnie strzeżoną tajemnicą branży.

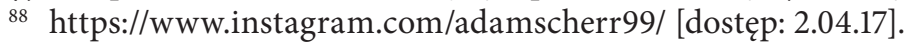

89 C. Jericho, Attack of the Fans, [w:] idem, The Best In The World At What I Have No Idea, New York 2014, s. 47. 


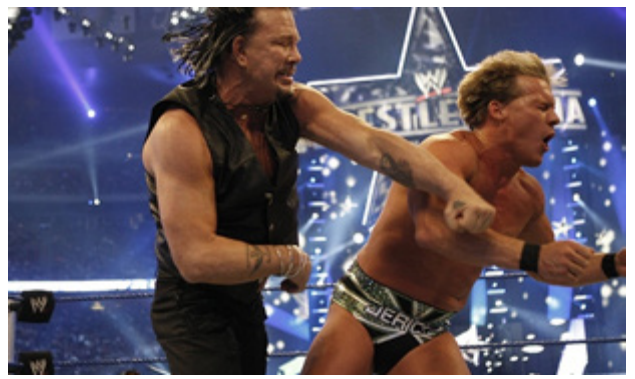

Il. 9. Mickey Rourke "nokautuje" Chrisa Jericho podczas Wrestlemanii 25

Jericho przywołuje w swojej autobiografii sytuację z 2009 roku. Przygotowania do dwudziestej piątej edycji Wrestlemanii - największego pokazu w kalendarzu imprez WWE - zbiegły się wówczas z premierą filmu Darrena Aronofsky'ego Zapaśnik, w którym reżyser zdradza kulisy funkcjonowania biznesu. $Z$ tej okazji do prestiżowego talk show Larry’ego Kinga zaproszony został Mickey Rourke, wcielający się w głównego bohatera filmu - Randy'ego „The Rama” Robinsona, oraz Jericho, który miał wyzwać aktora na pojedynek. W programie doszło do ostrej wymiany zdań, która miała stanowić fundament ich rywalizacji, a w której performer (w roli heela) nazwał Rourke’a figurantem i podważył jego umiejętności zapaśnicze. Nieświadomy konwencji aktor uznał to za zniewagę i obraził się na performera, w napadzie wściekłości grożąc mu później pobiciem ${ }^{90}$. Do właściwej walki nie doszło, choć aktor zgodził się wziąć udział w krótkim skeczu, w którym - ku uciesze zgromadzonej w hali publiczności - sprowokowany przez Jericho wymierza zapaśnikowi nokautujący cios ${ }^{91}$.

Tego typu incydenty należą jednak do wyjątków. Ze względu na globalny zasięg wrestlingu głównego nurtu, szereg działań charytatywnych, w jakie angażują się organizacje ${ }^{92}, \mathrm{i}$ coraz większą rolę marek personalnych

${ }^{90}$ Groźba ta nie była bez pokrycia - Rourke poza karierą aktorską brał także udział w amatorskich i profesjonalnych walkach bokserskich. Przyczyniły się one wraz z serią nieudanych operacji plastycznych - do znacznej deformacji twarzy aktora.

${ }^{91}$ Zob. C. Jericho, Rourke's Dorks, [w:] idem, op. cit., s. 85-88.

${ }^{2}$ Samo WWE angażuje się w kilkanaście kampanii społecznych, m.in. B.A. Star - mającej przeciwdziałać przemocy wśród młodzieży, Connor's Cure wspierającej badania nad nowotworami dziecięcymi, czy Susan G. Komen For Cure - promującej wczesną diagnostykę nowotworów piersi. 
najpopularniejszych performerów ${ }^{93}$ zawodnicy zobowiązani są do unikania skandali i przyzwoitego zachowania także poza ringiem.

\subsubsection{Scenariusz i fabuła pro wrestlingu}

Narracja ma w pro wrestlingu charakter ciągły, bezustanny. Składają się na nią nie tylko rywalizacje i skecze tworzone „tu i teraz”, ale i kumulowane przez dziesięciolecia historie, anegdoty i statystyki, tworzące wciąż żywą mitologię. Proces ten odbywa się w sposób transmedialny ${ }^{94}$. Narracja tworzona jest nie tylko drogą przekazu telewizyjnego ${ }^{95}$ (przez treść przemówień, komentarze, przebieg pojedynków i poczynania bohaterów), ale i poza nim. Fabułę tworzą informacje podawane w branżowych mediach (dostarczane przez „tajemniczych informatorów”), a także treści publikowane w przestrzeni internetowej. Duże organizacje obecne są na wielu platformach - ich pracownicy dbają o aktywność w serwisach społecznościowych, redagują i aktualizują strony internetowe (gdzie zamieszczają skróty pojedynków i skeczy, fotografie z pokazów nieemitowanych w telewizji, a także sesje fotograficzne przygotowywane specjalnie na potrzeby witryny). Dzięki platformie YouTube aktualne rywalizacje wzbogacane są o „ekskluzywne wywiady” przeprowadzane z postaciami tuż przed wydarzeniami emitowanymi w telewizji lub po nich. Media społecznościowe, takie jak Facebook, Twitter czy Instagram, umożliwiają zawodnikom nawiązywanie interakcji z fanami i z sobą nawzajem (dzięki czemu performerzy mogą rozwijać rywalizacje i wątki fabularne, na które nie wystarczy czasu podczas trwania pokazu). Istotność tych narzędzi opiera się na tym, że wiążą się one z natychmiastową informacją zwrotną dla organizacji, a negatywne komentarze sporej części społeczności niejednokrotnie doprowadziły do dużych zmian

${ }^{93}$ O markach personalnych piszę więcej w części czwartej - Pro wrestling w kulturze popularnej.

94 To jest - przedstawiany w różnych środkach przekazu.

${ }_{95} \mathrm{~W}$ przypadku organizacji WWE są to nie tylko audycje skupione ściśle na wrestlingu, ale i programy typu reality show zdradzające kulisy życia prywatnego wybranych zawodników. Piszę o nich więcej w części czwartej - Pro wrestling w kulturze popularnej. 
w planowanych projektach ${ }^{96}$. Z kolei gry wideo (w przypadku marki WWE wydawane corocznie) prezentują narrację alternatywną - unikalne i interaktywne historie stworzone przez scenarzystów specjalnie na potrzeby tegoż medium.

W przypadku pokazów przeznaczonych do emisji w telewizji lub Internecie scenariusz obejmuje najdrobniejsze szczegóły planowanych rywalizacji - rozkład interakcji między zawodnikami, poszczególne pojedynki i werbalne potyczki (improwizowane według wcześniej zaproponowanego schematu lub przygotowane przez scenarzystów). Konflikt musi być przy tym (przynajmniej w wariancie amerykańskim) podszyty osobistymi niesnaskami - im bardziej intymnymi, z tym większą uwagą śledzonymi przez widzów nieświadomych kayfabe'u ${ }^{97}$. Samo mistrzostwo sprowadzane jest wówczas do roli gadżetu, dodatku do starcia się wyrazistych osobowości, rywalizacji motywowanych zdradą lub splamionym honorem ${ }^{98}$.

Constantino Oliva i Gordon Calleja typ narracji stosowanej w pro wrestlingu określają mianem alterbiog rafi $\mathrm{i}^{99}$. Wydarzenia fikcyjne przeplatają się bowiem z realnymi, a do skryptu nierzadko włącza się także przypadkowe incydenty z ringu (np. sytuacje, gdy heel bierze na siebie odpowiedzialność za kontuzję popularnego zawodnika, twierdząc, iż skrzywdził

96 Aktywność fanów w mediach społecznościowych zapoczątkowała feministyczną rewolucję $\mathrm{w}$ programach produkowanych przez WWE. Widzowie, niezadowoleni ze sposobu, w jaki organizacja traktuje swoje performerki, wysyłali tysiące wiadomości opatrzonych tagiem \#GiveDivasAChance (ang. „dajcie diwom [określenie, jakim wówczas nazywano współpracujące z WWE kobiety - przyp. J.B.] szansę"), wskutek czego walki zawodniczek zyskiwały coraz większy limit czasowy i staranniej przygotowywane scenariusze. Podobna sytuacja wywołana została przez ruch \#OccupyRaw (nawiązujący do nazwy i działania ruchu Occupy Wall Street wymierzonego przeciwko wyzyskowi korporacji i banków), który wymógł na organizacji zmianę walki wieczoru Wrestlemanii 30, tak by mógł w niej wziąć udział także ulubieniec publiczności, Daniel Bryan.

${ }_{97}$ Smart marks próbują wówczas przewidywać przebieg wydarzeń i oceniają jakość samego scenariusza.

98 S. Mazer, op. cit., s. 28.

99 G. Calleja, C. Oliva, Fake Rules, Real Fiction: Professional Wrestling and Videogames, http://www.digra.org/digital-library/publications/fake-rules-real-fiction-professional-wrestling-and-videogames/ [dostęp: 6.04.2017]. 
go celowo) lub spoza niego. W ostatnich latach szczególnego znaczenia nabrało, owiane dotychczas tajemnicą, życie prywatne zawodników - dzięki serii programów typu reality show ich życiowe perypetie (odpowiednio udramatyzowane i fikcjonalizowane na potrzeby medium) także wpisane zostają do narracji i wykorzystywane jako zalążki lub uzupełnienie zapaśniczych rywalizacji. Alterbiograficzny charakter skryptów dotyczy także samych postaci, $w$ jakie wcielają się performerzy; w wielu przypadkach są to bowiem wyolbrzymione cechy osobowości samych zawodników. Chcąc nadać rywalizacjom pozór realizmu, promotorzy czasem sięgają po intymne szczegóły z życiorysu aktorów przedstawienia i wykorzystują w narracji na przykład ich skrzętnie skrywane trudne dzieciństwo albo problemy z nadużywaniem alkoholu lub substancji psychoaktywnych.

\subsubsection{Symbolika miejsca}

Istotne z punktu widzenia narracji jest również miejsce, w którym odbywa się pokaz. Konwencja kayfabe ściśle powiązana jest bowiem z historią pisaną przez samych promotorów, skrzętnie archiwizowaną na taśmach telewizyjnych, łamach specjalistycznych czasopism i internetowych forach zarówno przez branżowych dziennikarzy, jak i zapalonych miłośników. Wydarzenia jednogłośnie uznawane za przełomowe, kontrowersyjne lub szczególnie istotne prowadzą do swoistej mitologizacji lokacji, na stałe włączającej dane miejsca do bezustannie kumulowanej fabuły. Stąd nowojorska hala Madison Square Garden, mimo bogatej historii obiektu, w świadomości fanów wrestlingu na zawsze już będzie miejscem narodzin Wrestlemanii, Montreal obudzi wspomnienie słynnego przekrętu z gali Survivor Series $1997^{100}$, a Filadelfia czy nowojorska sala Hammerstein Ballroom natychmiast skojarzą się z organizacją ECW - mekką pojedynków typu hardcore.

100 W roku 1997 Bret Hart, jedna z największych gwiazd wrestlingu swoich czasów, nawiązał współpracę z konkurencyjną wobec WWF organizacją WCW. Hart, mimo iż był wówczas mistrzem WWF, zapowiedział promotorowi zamiar nieprzedłużenia kontraktu $\mathrm{z}$ federacją-matką. Jego ostatnim dużym występem miał być pojedynek na gali Survivor Series, która odbywała się w kraju jego pochodzenia - Kanadzie, a konkretnie w Montrealu. Hart miał obronić tytuł mistrzowski, by stracić go następnego dnia, na nieco mniej prestiżowym pokazie Raw. Vince McMahon, prezes WWF, bez wiedzy Harta zadecydował jednak o zmianie wyniku 
Miejsca te stają się tożsame z ich mityczną nadbudową, przywoływaną możliwie jak najczęściej, zarówno wprost (np. przez komentatorów), jak i pośrednio, na przykład przez zainscenizowanie ikonicznych wydarzeń w toku walki lub podczas skeczu ${ }^{101}$.

Elementem fabuły staje się także pochodzenie performerów i postaci przez nich kreowanych (nie zawsze jest to bowiem tożsame). Występ w miejscu pochodzenia wiąże się z przewagą psychologiczną jednego z performerów, zwykle podkreślaną w narracji na przykład przez komentatorów. Często w ramach niespodzianki dla zgromadzonej w hali publiczności na pokazy zapraszany jest tak zwany hometown hero - weteran branży pochodzący $\mathrm{z}$ danego miasta ${ }^{102}$. W przypadku pojedynków o podwyższonym prestiżu rozgrywających się o tytuły mistrzowskie lub wieńczących dłuższą rywalizację - aspekt ten może stać się centralnym punktem narracji, wielokrotnie zaznaczanym w przemówieniach i wywiadach. Zwycięstwo lub porażka na oczach publiczności z rodzinnego miasta nabiera bowiem - w myśl postulowanej przez Barthes'a estetyki przesady - dużo większego rozmachu.

Miejsce pochodzenia stanowi istotną część tożsamości kreowanej postaci, a także jej alterbiografii. Przykładowo, The Miz - postać sceniczna

walki, chcąc w ten sposób ukarać mistrza i upokorzyć go na oczach rodzimej publiczności. W kulminacyjnym momencie pojedynku Shawn Michaels (skonfliktowany z Hartem także w prawdziwym życiu) zapiął na Harcie jego własną dźwignię, a McMahon od razu nakazał zakończyć walkę, choć mistrz nie poddał się. Incydent ten, przez wielu specjalistów branży uznawany za nieoficjalny początek Ery Attitude, przeszedł do historii pod nazwą „Montreal screwjob” (dosł. „przekręt z Montrealu"). Jego kulisy przedstawione zostały w filmie dokumentalnym Hitman Hart: wrestling z cieniami, 1998, reż. Paul Jay.

101 Tak było na przykład podczas gali WWE Breaking Point we wrześniu 2009 roku w Montrealu. Walka wieczoru zakończyła się w sposób zbliżony do wspomnianego wcześniej Survivor Series 1997. Przykładem takiego nawiązania jest także koncepcja pokazów ECW One Night Stand, które w 2005 i 2006 roku zorganizowano w słynnej sali Hammerstein Ballroom. Ideą pokazów było jednorazowe przywrócenie aury pokazów organizacji ECW (wraz z występami związanych z nią zawodników), wykupionej w 2001 roku przez WWF.

102 W żargonie istnieje pojęcie Philly pop, które oznacza wykorzystywanie performerów związanych i utożsamianych z marką ECW (tak zwani ECW Originals) przez promotorów organizujących pokazy w Filadelfii. 


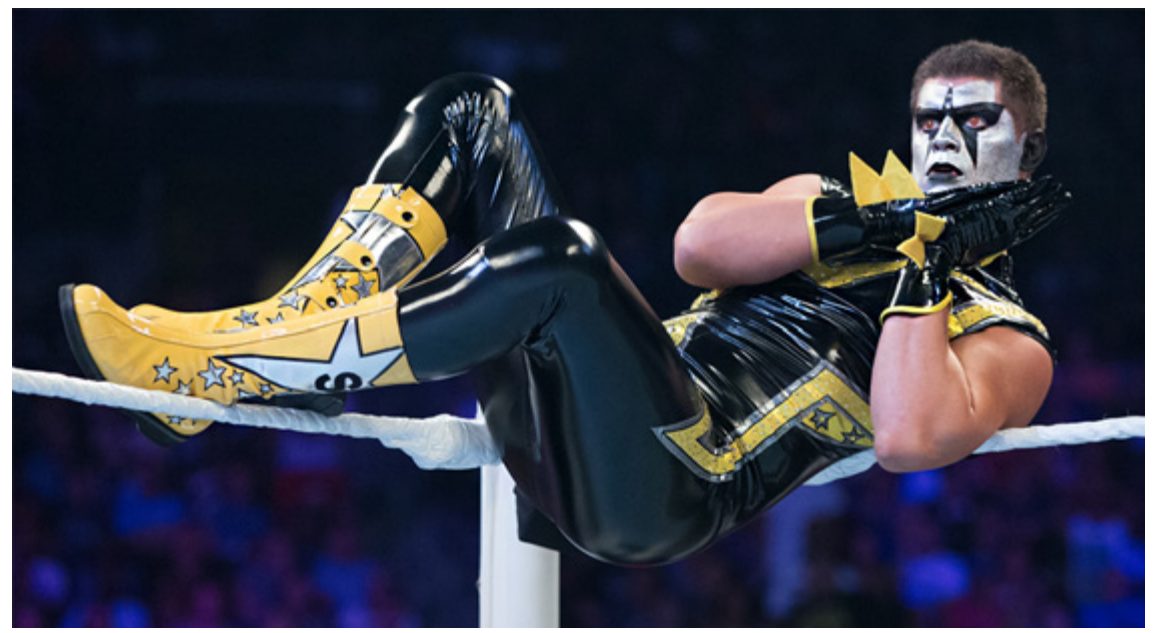

Il. 10. Stardust - tajemniczy przybysz z innego wymiaru

pochodzącego z Cleveland Mike'a Mizanina - to aspirujący celebryta i aktor kina akcji; by podkreślić ten aspekt, przedstawiający go konferansjer pomija rodzinne miasto performera, podając w zamian miejsce zamieszkania Hollywood. Chcąc z kolei wykreować postać tajemniczą lub wręcz nadprzyrodzoną, przypisuje się do niej miejsce nieprawdopodobne (jak Dolina Śmierci w przypadku postaci The Undertakera - grabarza o nadprzyrodzonych mocach) lub fikcyjne (będący pastiszem komiksowych złoczyńców Stardust miałby pochodzić z bliżej nieokreślonego „Piątego Wymiaru”). Podobnym zabiegiem jest także nieprzypisanie miejsca; stosowany jest wówczas zwrot „from parts unknown” - można podejrzewać, iż postać „znikąd”, jako że nie przystaje do otaczającej rzeczywistości lub legitymuje się mglistą przeszłością, będzie zachowywać się nieprzewidywalnie i wzbudzi strach.

\subsection{6. „Czwarta ściana” i jej przełamywanie}

Pojęcie „czwartej ściany” - symbolicznej granicy między aktorami a widownią - funkcjonuje w pro wrestlingu na innych zasadach niż ta sama umowa w kinie czy teatrze. Wynika to $\mathrm{z}$ faktu, iż widz zapaśniczego spektaklu pośrednio jest również jego aktorem, a jego reakcje mają realny wpływ na przebieg opowiadanej historii. Podobnie jak sami zawodnicy, sędziowie czy komentatorzy, widzowie także mają do odegrania konkretną rolę, której 
uczą się, obserwując innych zaangażowanych odbiorców (ukazywanych w zbliżeniach przez realizatorów przekazu telewizyjnego, dzięki czemu sugeruje się, czego promotor oczekuje od modelowego widza) ${ }^{103}$. Publiczność jest zatem pośrednim współtwórcą widowiska, mającym wpływ nie tylko na przebieg spontanicznie kreowanych pojedynków, ale i długofalowych strategii promotorów. Sposób, w jaki reaguje na danych performerów, może przełożyć się na to, jaką rolę będą oni odgrywali w bliższej bądź dalszej przyszłości - czy otrzymają oni push, czy też wręcz przeciwnie - ich rola zostanie ograniczona ${ }^{104}$.

Umowna „czwarta ściana” w dużej mierze pokrywa się z zakresem konwencji kayfabe. W przeciwieństwie do konwencji kinowej, strategie takie jak bezpośredni zwrot do odbiorcy i spoglądanie wprost w oko kamery są tu wręcz pożądane (pozwalają bowiem widzom zasiadającym przed telewizorami poczuć silniejszą identyfikację z produktem). Przełamanie „czwartej ściany” jest tu zatem równoznaczne z przełamaniem ustalonej konwencji, obejmującym wszystkie wydarzenia spontaniczne, nieplanowane (w tym kontuzje performerów) lub w inny sposób wykraczające poza skrypt. Zabieg ten określany jest mianem shootu (lub worked shootu, jeśli przełamanie konwencji jest ustalone wcześniej z promotorem).

\subsection{WRESTLING JAKO PARODIA SPORTU - KARNAWALIZACJA}

Nie sposób nie zauważyć specyficznego charakteru pro wrestlingu - widowiska, które ustala zasady tylko po to, by móc je podważyć; wytwarza hierarchie tylko po to, by móc dowolnie je modyfikować. W rzeczywistości tej, w której prym wiodą przesada i zły smak. Jest to świat na opak - parodia zarówno sportu, jak i szarej codzienności.

Słuszne wydają się zatem skojarzenia z Bachtinowską teorią ka rna wa li zacji. John Fiske nazywa wrestling „telewizyjnym karnawałem ciał,

\footnotetext{
103 S. Mazer, op. cit., s. 49.

104 Należy przy tym pamiętać, iż organizacja zapaśnicza jest przede wszystkim przedsiębiorstwem nastawionym na zysk, a decyzja o promowaniu konkretnych zawodników najczęściej jest decyzją nie tyle kreatywną, ile biznesową. Sympatia, jaką darzeni są performerzy, przekłada się na sprzedaż biletów, pokazów w systemie PPV i licencjonowanych towarów.
} 
podważania reguł, groteskowości, degradacji i widowiskowości”105. Jak zauważa:

Wrestling jest parodią sportu: wyolbrzymia do przesady niektóre jego elementy, aby dać sobie możliwość zakwestionowania zarówno ich samych, jak i wartości, którym normalnie hołdują. [...] Walka toczy się więc między tym, co normalne, a tym, co nienormalne, między codziennością a karnawalizacją ${ }^{106}$.

Podobne wnioski przedstawia Sharon Mazer:

Podczas gdy pro wrestling nie jest akceptowany jako prawdziwy sport - jak również nie może być postrzegany jako prawdziwy teatr - w istocie obnaża, wykorzystuje $\mathrm{i}-\mathrm{w}$ końcu - parodiuje obie formy rozrywki ${ }^{107}$.

Karnawałowość zapasów profesjonalnych przejawia się również w aspekcie cielesności widowiska - fizyczne ekscesy łączą się tu ze sprzeciwem wobec ustalonego porządku instytucjonalnego. Przyjemność wynikająca $\mathrm{z}$ cielesności (nawet $\mathrm{z}$ perspektywy obserwatora) przeciwstawia się moralności, dyscyplinie i kontroli społecznej ${ }^{108}$. Ciało nie jest ciałem indywidualnym, ale materialną reprezentacją wymiaru społecznego ${ }^{109}$ przejawiającą się $\mathrm{w}$ archetypach postaci wytworzonych przez tę dyscyplinę na jej potrzeby.

\subsubsection{Hierarchia i jej zaburzenie}

W odróżnieniu od większości sportów walki wrestling pozbawiony jest kategorii wagowych. Tak jak karnawał, widowisko to jest egalitarne, dąży do równości. Choć przed samym pojedynkiem konferansjer podaje wzrost i wagę zawodników (często zresztą zawyżane lub zaniżane na potrzeby narracji i kayfabe’u), informacje te nie mają większego znaczenia dla formalnego statusu samej walki. Nic nie stoi bowiem na przeszkodzie, by jakiś „Dawid”

105 J. Fiske, Wyzywająca cielesność i przyjemności karnawałowe, [w:] idem, Zrozumieć kulturę popularna, tłum. K. Sawicka, Kraków 2010, s. 87.

106 Ibidem, s. 90-91.

107 S. Mazer, op. cit., s. 21.

108 J. Fiske, op. cit., s. 86.

109 Ibidem, s. 87. 
zmierzył się z wielokrotnie od siebie masywniejszym „Goliatem”. Co więcej, znacząca różnica gabarytów sama w sobie jest źródłem opowieści.

Hierarchia jest tu natomiast ustalana sztucznie, wręcz uznaniowo. Można oczywiście przyjąć pewne wyznaczniki statusu, takie jak staż kariery lub liczba zdobytych wyróżnień, koniec końców jest to jednak struktura dynamiczna, niepodlegająca żadnym sprecyzowanym standardom. Jedynym pewnikiem okazuje się sprzeciw wobec ustalonego porządku ${ }^{110}$. Jest to de facto - podobnie jak rzeczywistość karnawałowa - „świat bez hierarchii, bez warstw społecznych”"111, a także „trawestacja sprawiedliwości”112.

\subsubsection{Wrestling jako zjawisko kontrkulturowe}

Zarówno Sharon Mazer, jak i Bolesław Racięski uznają zapasy profesjonalne za zjawisko kontrkulturowe. Z oczywistych powodów sytuuje się ono w opozycji do kultury wysokiej. Sharon Mazer wspomina o początkowej niechęci, jaką darzyli ją przedstawiciele badanego przez nią środowiska pro wrestlingu. Jako osoba związana ze środowiskiem akademickim postrzegana była bowiem jako przedstawicielka kultury dominującej - tej, która świadomie marginalizuje pro wrestling jako rozrywkę niższych klas społecznych $^{113}$.

Środowisko performerów i ich fanów to środowisko insiderów posługujących się sobie tylko właściwym żargonem i autoreferencyjną mitologią. Zapaśniczy spektakl to z kolei wydarzenie wyjęte spod obowiązujących norm i przepisów, tworzące, ku uciesze widowni, nowe reguły i własnych bohaterów reprezentujących abstrakcyjne kategorie dobra i zła.

[...] wiejska publiczność, doskonale zdająca sobie sprawę z tego, że wydarzenia na ringu są zaprogramowane, i tak czerpie przyjemność $z$ widowiska, ponieważ czyta je jako krytykę kapitalistycznej etyki pracy. Cechy kojarzące się z wrestlingiem - między innymi nieposzanowanie zasad fair play oraz rozstrzyganie wyniku za zamkniętymi drzwiami - dramatyzują niezgodność między ideologią liberalnego kapitalizmu a jego praktyką, której doświadczają drobni kanadyjscy farmerzy. Podobnie lucha libre funkcjonuje

\footnotetext{
110 Ibidem, s. 86.

111 Ibidem.

112 Ibidem, s. 91.

113 S. Mazer, op. cit., s. 12.
} 
jako przestrzeń, w której widzowie mogą oddawać się krytyce panujących uwarunkowań społecznych. Arena jest przestrzenią transgresji, w której publiczność wykrzykuje hasła publicznie zabronione $e^{114}$.

Wrestling znajduje się w opozycji także wobec kultury popularnej i masowej, z jednej strony czerpiąc z nich inspiracje, z drugiej zaś - ośmieszając i demaskując kuriozalne schematy. Jest sztuką złą, ale złą z premedytacją, co nadaje mu wymiar kampowy. To popkulturowy kolaż pełen ironii i dystansu, miłujący sztuczność i przesadę ${ }^{115}$.

\section{STEREOTYPY}

Opowieść nie może być w pro wrestlingu zbyt skomplikowana; znak musi być jednoznaczny - tak, by możliwe było jego natychmiastowe odczytanie a motywy postaci - wyraziste, zrozumiałe bez namysłu. Stąd też umiłowanie promotorów do stereotypów dotyczących płci lub mniejszości narodowych, etnicznych bądź seksualnych. Na przestrzeni dekad narracja ta wytworzyła także swoiste archetypy - tropy powtarzające się i powracające bez względu na upływ czasu.

\subsection{KOBIECOŚĆ I MĘSKOŚĆ W PRO WRESTLINGU}

Choć na pierwszy rzut oka może się wydawać, iż pro wrestling - widowisko kojarzone przede wszystkim z błyszczącymi od olejku, muskularnymi mężczyznami - prezentować będzie jednorodny wzorzec cielesności, w istocie jest wręcz odwrotnie. Sharon Mazer kategoryzuje je bowiem jako zjawisko wysoce egalitarne i transgresyjne ${ }^{116}$, podważające ustalone i funkcjonujące w powszechnej świadomości kanony męskości i kobiecości.

\subsubsection{Ciało}

Jak zauważa Roland Barthes, „ciało zawodnika okazuje się [...] pierwszym kluczem do zrozumienia walki"117. Jest ono nie tylko nośnikiem znaczeń czystym płótnem, gotowym, by na nim tworzyć - ale i znakiem samym

114 B. Racięski, op. cit., s. 90.

115 Zob. S. Sontag, Notatki o kampie, tłum. W. Wertenstein, „Literatura na Świecie” 1979, nr 9, s. 307.

116 S. Mazer, op. cit., s. 6.

117 R. Barthes, op. cit., s. 33. 


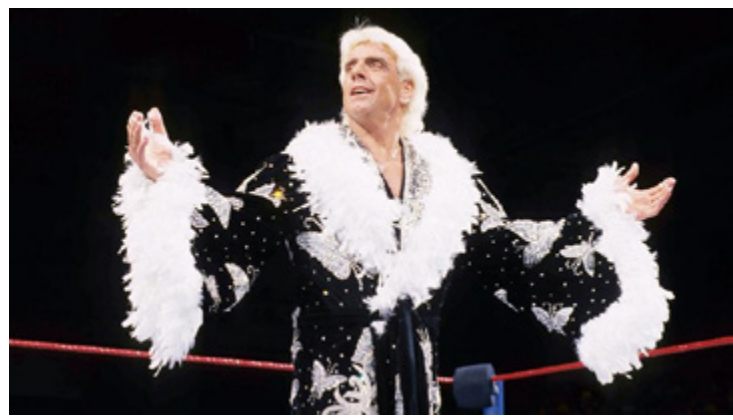

Il. 11. Ric Flair - esencja kampowej ekstrawagancji w sobie. Aparycja performerów (zarówno indywidualne warunki fizyczne, jak i ich swoista nadbudowa - kostium oraz charakteryzacja) to bowiem pierwszy bodziec wizualny, z jakim spotyka się odbiorca, zanim jeszcze rozpocznie się walka.

Zawodnicy mają [...] wygląd równie nieodparty, jak postaci z komedii dell'arte, których stroje i postawy zapowiadają z góry przyszłą treść ich ról: podobnie jak Pantalon może być tylko śmiesznym rogaczem, Arlekin podstępnym sługą, a Doktor głupawym pedantem, tak i Thauvin [opisywany przez Barthes’a złoczyńca charakteryzujący się „bezpłciową brzydotą" $i$ „prostackimi rysami” - przyp. J.B.] będzie zawsze tylko prostackim zdrajcą, Reinieres (wysoki blondyn o giętkim ciele i zwichrzonych włosach) podniecającym obrazem bierności, Mazaud (arogancki kogucik) obrazem groteskowej próżności, a Orsano (sfeminizowany bikiniarz pojawiający się na początku w niebiesko-różowym szlafroku) w dwójnasób sarkastycznym obrazem mściwej zdziry ${ }^{118}$.

Wyrazista fizjonomia i strój przemawiają za bohatera, zanim jeszcze zabrzmi pierwszy gong. Zadbane, wysportowane ciała budzą pozytywne konotacje, natomiast te obłe, naznaczone nadwagą bądź innymi deformacjami zwykle stają się domeną złoczyńców. Brzydota bowiem, jak podkreśla Barthes:

służy tu nie tylko do oznaczenia podłości, ale dodatkowo cała skupia się w materii szczególnie obrzydliwej, [...] powodując, że namiętne potępienie tłumu nie tylko wykracza poza granice rozsądku, ale bierze się wprost z samej głębi jego odrazy ${ }^{119}$.

118 Ibidem, s. 34 .

119 Ibidem, s. 33. 
John Fiske z kolei brzydotę odczytuje jako formę wypowiedzi - sprzeciwu wobec przyjętych norm (będących przecież przejawem kulturowej dominacji):

A więc brzydota wielu zapaśników jest formą wypowiedzi społecznej, akcentem grupy podporządkowanej, który jednak czasem przybiera inny kształt staje się przesadnym odwróceniem. Wielu zawodników jest dziś również kulturystami, ponieważ [...] wyolbrzymiają normy określające „dobre” ciało, przez co wykraczają poza „oficjalne” funkcje zdrowia i wydajności i stają się widowiskiem ${ }^{120}$.

W związku z tym ciało zawodnika niejako wyzbywa się swojej podmiotowości, zostaje utekstowione i uprzedmiotowione (sam zawodnik staje się bowiem przedmiotem widowiska), a w skrajnych przypadkach wręcz utowarowione ${ }^{121}$. Cielesność ta ma wymiar społeczny, inkluzywny. „Panuje równość, która zawiesza działanie hierarchii i przywilejów, [...] sprowadza wszystkich do równego statusu na poziomie cielesności"122.

Wobec tego pojęcie normy wydaje się nie obowiązywać w świecie pro wrestlingu. Można jednak zauważyć tendencje i trendy, a także pożądane typy budowy ciała performerów, które kształtowały wizerunek dyscypliny na przestrzeni lat ${ }^{123}$. Oczywisty jest przy tym wymóg ponadprzeciętnej sprawności fizycznej. Nieco mniej intuicyjne okazuje się uchwycenie samej koncepcji męskości i kobiecości.

120 J. Fiske, op. cit., s. 98.

121 W przypadku popularnych postaci częstą praktyką jest zastrzeganie znaków towarowych obejmujących znaczną część przedstawienia: pseudonimy artystyczne, wykorzystywane w przemowach slogany, charakterystyczne dla danych postaci kolory, a nawet elementy fizjonomiczne zawodników (w środowisku fanowskim krąży legenda, jakoby znakiem towarowym miał być objęty m.in. charakterystyczny wąs Hulka Hogana).

122 J. Fiske, op. cit., s. 87.

123 Dotyczą one przede wszystkim ciał męskich, jako że - co podkreślają zarówno Sharon Mazer, jak i John Fiske - zapasy kobiet do niedawna były zjawiskiem marginalizowanym, przez co preferowany wzorzec kobiecości nie ulegał (przynajmniej w organizacjach głównego nurtu) większym zmianom. 


\subsubsection{Modelowy wzorzec kobiecy i męski}

„Kim jest "prawdziwy« mężczyzna?” - pyta Sharon Mazer, po czym przywołuje nazwisko Gorgeous George’a, wielokrotnego mistrza zapasów słynącego z burzy nienagannie wystylizowanych loków, zdobionych kryształami peleryn, a także gestów, które w tradycyjnym rozumieniu męskości zapewne zostałyby uznane za zniewieściałe. „Kim jest "prawdziwy« mężczyzna?” pyta ponownie, wymieniając kolejne nazwiska postaci narcystycznych, do przesady przejętych swoją prezencją - a więc mających cechy, które stereotypowo utożsamiamy z kobiecością ${ }^{124}$. Rozszerzę zagadnienie, które nurtuje Sharon Mazer, i zapytam również: co konstytuuje „prawdziwą” kobietę? W myśl konwencji stylistycznej kampu każda odpowiedź na te pytania jest właściwa, bowiem:

Kamp darzy szczególnym upodobaniem osoby [...] odbiegające od normy. Hermafrodyta jest na pewno jednym ze wzorców wrażliwości kampu. [...] Najbardziej wyrafinowana forma atrakcyjności seksualnej [...] polega na postępowaniu wbrew własnej płci. W bardzo męskich mężczyznach najpiękniejszy jest właśnie jakiś element kobiecości, w najbardziej kobiecych kobietach najpiękniejszy jest jakiś rys męski ${ }^{125}$.

Wewnątrz ringu wszyscy są równi, dlatego też męskość narcystycznego adonisa niczym nie będzie ustępować męskości krępego brutala. Górująca nad wszystkimi kulturystka jest kobieca w równym stopniu, co smukła, drobna blondyneczka. Cielesność karła okazuje się równie istotna, co imponująca postura giganta. Wrestling charakteryzuje egalitarny, inkluzywny wzorzec fizjonomii i aparycji, a także normalizacja tego, co - w powszechnym ujęciu - poza normę wykracza. Ma to jednak w przypadku rozrywki sportowej przyziemny, by nie powiedzieć: cyniczny, powód. Należy pamiętać, iż jest to przede wszystkim lukratywny biznes, a maksymalne rozszerzenie docelowego grona odbiorców znacząco zwiększa szanse na pomnożenie potencjalnych przychodów.

124 S. Mazer, op. cit., s. 96.
125 S. Sontag, op. cit., s. 311-312. 


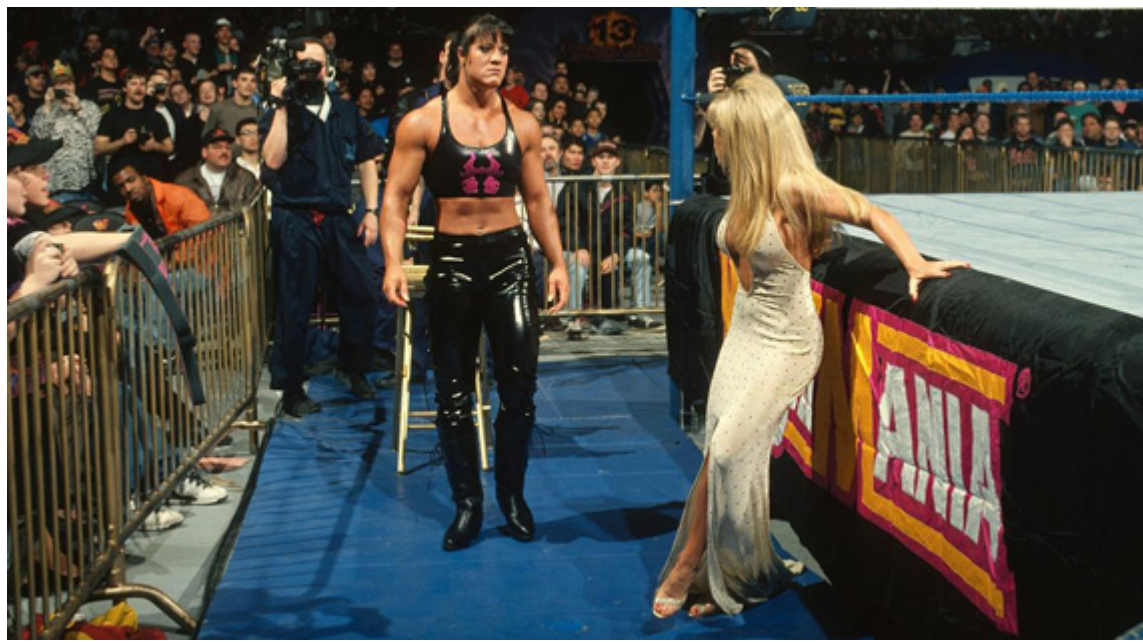

Il. 12. Subwersja norm. Egalitarny charakter show najbardziej widoczny jest w przypadku zestawienia przykładów skrajnych

\subsection{STEREOTYPY ETNICZNE I NARODOWE}

Wymóg przezroczystości przekazu wiąże się z jego maksymalnym uproszczeniem, stąd też stereotypizacja obecna jest w pro wrestlingu od początków funkcjonowania dyscypliny. Już pierwsze pokazy puroresu proponowały postać Złego Cudzoziemca - motyw, który amerykańscy promotorzy rozwijają do dziś, a który w szczytowym momencie (lata 80. XX wieku) ocierał się o własną karykaturę. Przykładowo, postacie ze wschodnioeuropejskim rodowodem (niekoniecznie jednak odgrywane przez zawodników pochodzących z tamtego regionu) niemal zawsze wyznawały wartości uznawane za oceanem za „antyamerykańskie”; drużyna „Bolszewików” - Nikolai Volkoff i Boris Zhukov - przed każdym pojedynkiem dumnie intonowała hymn Związku Radzieckiego, natomiast debiutujący w 2008 roku Vladimir Kozlov (w którego wcielał się ukraiński zapaśnik Oleg Prudius) prawie dwadzieścia lat po upadku ZSRR wciąż nosił czerwone spodenki i określany był mianem „Sowieckiej Maszyny Wojennej” czy „Sowieckiego Cyborga”.

Zawodnicy samoańscy (z nielicznymi wyjątkami, jak choćby Dwayne „The Rock” Johnson) przedstawiani są jako ludzie dzicy, nieprzystający do zachodniej cywilizacji. Porozumiewają się bełkotliwymi okrzykami, a całe twarze pokryte mają quasi-rytualnymi malunkami. W konwencji kayfabe 


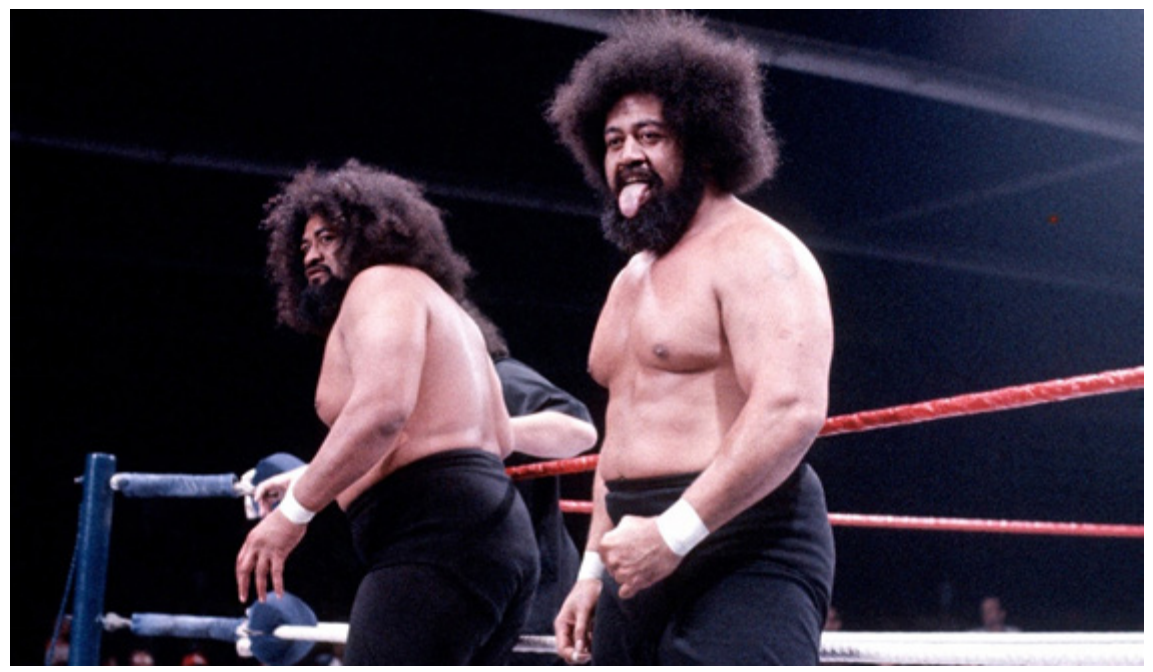

Il. 13. The Wild Samoans

funkcjonuje niemalże eugeniczna legenda, jakoby ich czaszki były twardsze niż czaszki ludzi innych narodowości. Mimo rasistowskiego zabarwienia, motyw ten kontynuowany jest do dziś, a tak zwane headbutt - uderzenie czołem - znajduje się w arsenale większości performerów samoańskiego pochodzenia. Warto zwrócić uwagę także na kostiumy. Przykładowo, pochodzący z Fidżi Jimmy „Superfly” Snuka każdorazowo przywdziewał na biodra i kostki przepaski z materiału zdobionego egzotycznym wzorem (zwykle były to tygrysie pasy bądź plamy lamparta), a walki odbywał boso, budując jednoznaczne skojarzenia $z$ wizerunkiem tubylca - dzikusa zamieszkującego tereny jeszcze nieodkryte, nieskolonizowane, a co za tym idzie - nieucywilizowane.

Japońska grupa zawodników Kai En Tai sprowadzona została w WWF do roli postaci komediowych. Ich przemówienia - będące przecież jedną z kluczowych strategii budowania postaci - poddawane były „dubbingowi” na żywo. Zawodnicy podnosili mikrofony i poruszali ustami, jednak z głośników wydobywał się głos angielskojęzycznego lektora. Ponadto menedżer drużyny, Pan Yamaguchi, w jednym ze scenariuszy miał wywoływać 
skojarzenia z japońską mafią - yakuzą ${ }^{126}$. Ówczesny przeciwnik grupy, Val Venis ${ }^{127}$, splamił honor (wartość nadrzędną w etosie samurajskim) jej lidera: dopuścił się uwiedzenia żony Yamaguchiego, na co starszy pan odpowiedział metaforyczną wizualizacją kary, jaka czekała gorszyciela - rozłożył on na stoliku kawałek kiełbasy, wyciągnął tradycyjny miecz samurajski - katanę, i przeciął kiełbasę, wykrzykując łamaną angielszczyzną: „I choppy choppy your pee pee!”.

Zawodnicy meksykańscy zwykle sprowadzani są przez amerykańskich promotorów, by odgrywać rolę zamaskowanych, milczących luchadorów, zdobywających sympatię widzów efektownymi akrobacjami, bez potrzeby wygłaszania długich i skomplikowanych przemówień. Ci jednak, którzy maskę utracili, nierzadko muszą mierzyć się z wizerunkami krzywdzącymi. Postać Eddiego Guerrero, członka szanowanego rodu luchadorów, początkowo opierała się na wyobrażeniu gorącokrwistego latynoskiego kochanka - macho (wykorzystującego naznaczone etnicznie slogany, takie jak Latino Heat czy Mamacita), by po latach, w rzekomo żartobliwy sposób, odzwierciedlać stereotyp o zdecydowanie bardziej negatywnym wydźwięku - drobnego oszusta. Wraz ze swoim siostrzeńcem, Chavo, wziął on wówczas udział w serii krótkich skeczy, w których para realizowała slogan „we lie, we cheat, we steal” („kłamiemy, kantujemy, kradniemy”). Podczas scenek mężczyźni dokonywali drobnych przekrętów: oszukiwali podczas gry w golfa, zachwycali się urodą brzydkiego niemowlęcia lub wmawiali starszej kobiecie, że przyszli naprawić basen, by później wyprawić nad nim przyjęcie.

Z podobnymi problemami zmagają się czarnoskórzy performerzy, postrzegani przede wszystkim przez pryzmat swojej rasy. Postacie, w które się wcielają, zwykle nawiązują do subkultury hiphopowej lub zorganizowanej działalności przestępczej (tak jak w przypadku postaci The Godfathera - sutenera, który wchodził do ringu w towarzystwie wianuszka skąpo ubranych kobiet - lub drużyny Cryme Tyme, stylizowanej na członków ulicznego gangu). Jak zauważa John Fiske, problem rasy najbardziej widoczny jest jednak w przypadku par lub drużyn mieszanych:

126 Sam jego pseudonim jest przy tym odwołaniem do największego gangu działającego w ramach struktur organizacyjnych yakuzy - Yamaguchi-gumi.

127 Skojarzenia dotyczące męskiego narządu płciowego były zapewne zamierzone - Venis odgrywał bowiem postać gwiazdora filmów pornograficznych. 
Rasowy wymiar tych ucieleśnionych stosunków społecznych można zaobserwować w mieszanych parach bohaterów [...], w których Murzyn, albo po prostu osoba mniej biała, zwykle będzie „ciałem” drużyny ${ }^{128}$.

Problem ten, nomen omen, ucieleśnia postać Virgila - czarnoskórego sługi „Million Dollar Mana” Teda DiBiasego - zarówno w kontekście stereotypów rasowych, jak i klasowych ${ }^{129}$. Virgil nie tylko wypełnia polecenia swojego szefa, ale i sprawia wrażenie kompletnie niemego - jedyną osobą, której wolno odzywać się w jego imieniu, jest właśnie DiBiase. Virgil jest więc nie tyle pracownikiem, ile pozbawioną wszelkich praw i osobistej autonomii własnością milionera. Układ ten - ciemnoskóry podwładny białego bogacza - budzi nieuchronne skojarzenia z niewolnictwem. „Groteskowe ciało Murzyna wyraża podporządkowanie jeszcze dobitniej niż ciało białego" ${ }^{130}$, do tego stopnia, że - jak twierdzi David Shoemaker - „największym osiągnięciem czarnoskórego wrestlera jest to, że przestaje być postrzegany jako czarnoskóry"131.

\subsection{ZAPAŚNICZE ARCHETYPY}

\subsubsection{Zły Szef / Dobry Szef}

Jeden z najbardziej wyrazistych archetypów postaci występujących w profesjonalnym wrestlingu jest też jednym z najnowszych - pojawił się on bowiem w drugiej połowie lat 90. XX wieku. Przedtem szef - promotor - był postacią niewidoczną i nieistotną fabularnie, wykonującą swą pracę za kulisami. Pojedynki ogłaszane były w komunikatach prasowych lub przez komentatorów, a ich siłę napędową stanowiły rywalizacje zawodników. Wzorzec przedstawiciela władzy jako postaci zaangażowanej w przedstawienie ma swoje źródło w opisywanym wcześniej incydencie z Montrealu i od tego czasu jest w zasadzie nieodłącznym elementem narracji.

Zły Szef utożsamiany jest z kulturą korporacyjną, bezduszną i wyzutą z szacunku do drugiego człowieka. Stawia on interes zarządu lub firmy ponad dobrem jednostki. „Dyrekcja” - The Authority, grupa zarządzająca

128 J. Fiske, op. cit., s. 101.

129 Ibidem, s. 102.

130 Ibidem.

131 C. Kelly, The New Day and Being Black In WWE, https://sports.vice.com/ en_ca/article/xybz4d/the-new-day-and-being-black-in-wwe, [dostęp: 6.04.2017]. 
programami WWE w latach 2013-2016 - w swoich przemówieniach mówiła wprost, że liczy się dla nich tylko to, co jest the best for business. Postacie te faworyzują czarne charaktery, jednocześnie gnębiąc i utrudniając pracę babyface'om. Notorycznie nadużywają przy tym swojej władzy. Przedstawiane są najczęściej w stroju formalnym, symbolizującym dystans zarówno wobec podwładnych, jak i widzów. Dystans ten manifestowany jest także w stosowanym dyskursie oficjalną mową z wyraźnie zarysowaną dychotomią „my” - „oni”.

Dobry Szef z kolei stara się zarządzać sprawiedliwie, pozostaje blisko ludzi (stąd często używane w jego wypowiedziach inkluzywne „my”) i chętnie wchodzi $\mathrm{w}$ interakcje, także $\mathrm{z}$ widzami. W ustalaniu pojedynków kieruje

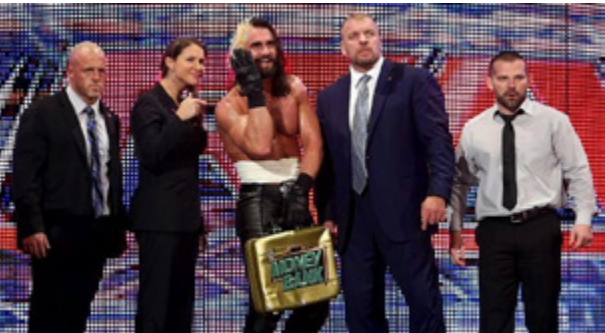

Il. 14. Trzonem „Dyrekcji” sa faktyczne władze WWE - członkini Rady Zarzadu Stephanie McMahon i jej maż, Paul Levesque (znany szerzej jako Triple H) - wiceprezes ds. kreatywnych

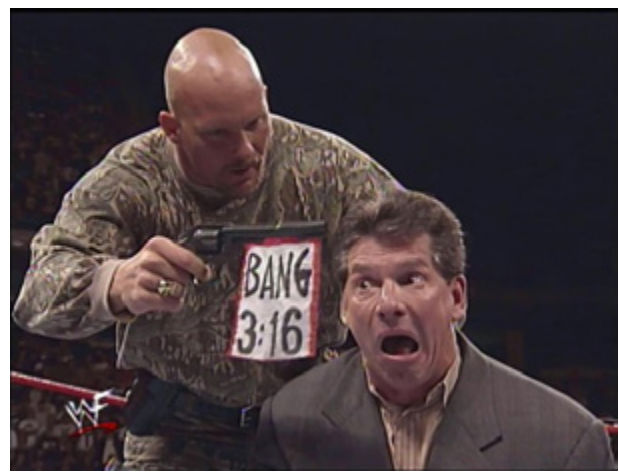

Il. 15. „Stone Cold” Steve Austin (Buntownik) publicznie ośmiesza Vince’a McMahona (Złego Szefa) się dobrem odbiorcy. Łamanie zasad i warunków wyznaczanych przez stypulacje jest przez niego karane (Zły Szef z kolei konsekwencje takich działań dostosuje do własnego interesu).

\subsubsection{Buntownik}

Archetyp Buntownika, podobnie jak motyw Dobrego i Złego Szefa, ma swoje źródła w Erze Attitude. Wraz z obnażeniem mechanizmu władzy pojawiła się bowiem potrzeba stworzenia równoważnego przeciwnika establishmentu - karnawałowego błazna ${ }^{132}$.

132 Nie oznacza to jednak, iż buntownik jest postacią ściśle komiczną; choć ośmiesza on władzę, jego pojedynki odbywają się jak najbardziej „na serio”. 
Buntownik jest rolą dla zawodników o wielkiej charyzmie. Jego funkcją jest obnażenie słabości władzy i ośmieszenie jej. To antykorporacyjny, kontrkulturowy lider, spełniający jedną z kluczowych, według Sharon Mazer, funkcji pro wrestlingu - stawiając czoła aparatowi opresji, Buntownik pozwala widzom dać upust głęboko skrywanym i tłumionym namiętnościom ${ }^{133}$. W swoich przemówieniach często puszcza oko w stronę "świadomych" fanów, używając techniki shootu (jako że przymus podporządkowania się konwencji kayfabe także jest elementem opresji władzy).

\subsubsection{Underdog}

Słowo 'underdog' w języku angielskim oznacza słabszego konkurenta stronę, której nie daje się większych szans na zwycięstwo w starciu z faworytem. W pro wrestlingu słabsza strona nie tylko konfrontowana jest z przeciwnikami wielokrotnie masywniejszymi i silniejszymi, ale i ma realne szanse na zwycięstwo.

Underdog to faworyt publiczności, jego naturalny urok wynika bowiem z pozornego nieprzystosowania do świata umięśnionych gigantów. Jego sylwetka nierzadko znacznie odbiega od wzorca zapaśnika - zwykle jest niższy, lżejszy lub mniej umięśniony od faworyzowanych performerów. Może także odstawać od większości ze względu na pozycję w hierarchii ${ }^{134}$, pochodzenie $^{135}$, osobiste przekonania ${ }^{136}$ lub fizyczne defekty ${ }^{137}$, a nawet płeć $^{138}$.

133 S. Mazer, op. cit., s. 21.

134 Przeciwstawianie mniej doświadczonych, „słabszych” zawodników - mistrzom lub weteranom jest częstym zabiegiem. Zwycięstwo Underdoga zapewnia utrzymanie pozorów nieprzewidywalności fabuły.

${ }_{135}$ Na przykład Bohater Klasy Robotniczej, o którym piszę poniżej.

136 Jak Daniel Bryan, wyśmiewany za przestrzeganie diety wegańskiej. Jest on kilkukrotnym mistrzem WWE.

137 Jak Zach Gowen, który w wieku ośmiu lat stracił lewą nogę wskutek powikłań po chorobie nowotworowej. Jak dotychczas jest on jedynym zapaśnikiem z niepełnosprawnością w historii WWE.

${ }_{138}$ Walki typu intergender odbywały się dość często w okresie Ery Attitude (słynęły z nich członkinie Hali Sław WWE - Lita i Alundra Blayze, a także Chyna jak dotychczas jedyna kobieta, której udało się zdobyć prestiżowe mistrzostwo Interkontynentalne). Do dziś zdarzają się one na pokazach organizacji niezależnych, 
Słabszy zawodnik łatwo wzbudza sympatię widzów, jako że w swej „przeciętności” postrzegany jest jako przedstawiciel ludu - człowiek taki, jak my.

\subsubsection{Bohater Klasy Robotniczej}

Bohater Klasy Robotniczej (Working Class Hero lub Blue Collar Job Guy) jest w pewnym sensie podtypem Underdoga, popularnym szczególnie na przełomie lat 70. i 80 . XX wieku. To postać wyróżniająca się ze względu na pochodzenie - dalekie od przywilejów i luksusów realia klasy robotniczej, uważanej wówczas za docelową grupę odbiorców pro wrestlingu. Publiczność sympatyzuje z nim, ponieważ łatwo może się z nim utożsamić.

Najbardziej znanym przykładem tego archetypu jest „The American Dream” Dusty Rhodes, dumnie podkreślający, iż jest synem hydraulika. W jednym z najsłynniejszych przemówień w historii dyscypliny przyznał on: „Ucztowałem z królami i królowymi, ale też spałem na ulicy i dojadałem wieprzowy gulasz"139. W innym przemówieniu, zatytułowanym Hard Times („Ciężkie czasy”) i wygłoszonym w trakcie rywalizacji z Rickiem Flairem (szesnastokrotnym mistrzem świata, ostentacyjnie obnoszącym się ze swoim bogactwem), odniósł się do pogarszającej się sytuacji materialnej pracowników najniższych szczebli. Rhodes zarzucił przeciwnikowi oderwanie od rzeczywistości - nie może wiedzieć, czym są ciężkie czasy, skoro przemieszcza się prywatnymi odrzutowcami i limuzynami, podczas gdy mniej uprzywilejowani obywatele tracą pracę i popadają w długi, zastępowani przez rozwijającą się technologię.

\subsubsection{Amerykański Patriota}

I am a real American.

Fight for the rights of every man,

I am a real American.

Fight for what's right, fight for your life! ${ }^{140}$

choć wciąż wzbudzają kontrowersje ze względu na skojarzenia z problemem przemocy domowej.

139 „I've wined and dined with kings and queens - but I've slept in alleys and dined on pork'n'beans". W Stanach Zjednoczonych pork and beans sprzedawany jest w puszkach i powszechnie uznaje się go za danie ludzi biednych.

140 R. Derringer, Real American, https://www.youtube.com/watch?v=w_ jHY1CXK0I [dostęp: 6.04.2017]. 


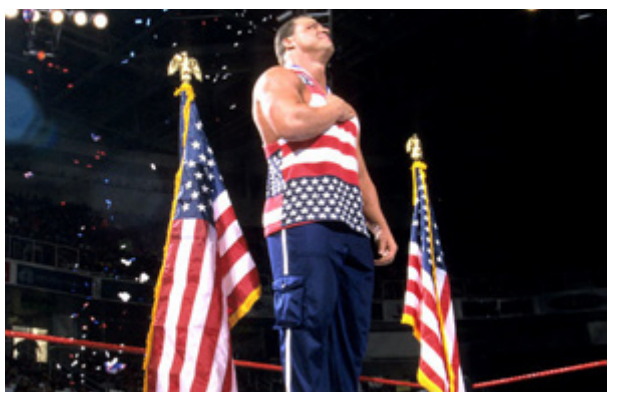

Il. 16. Kurt Angle, jeden z najpopularniejszych performerów Ery Attitude, jest jednocześnie złotym medalista Igrzysk Olimpijskich

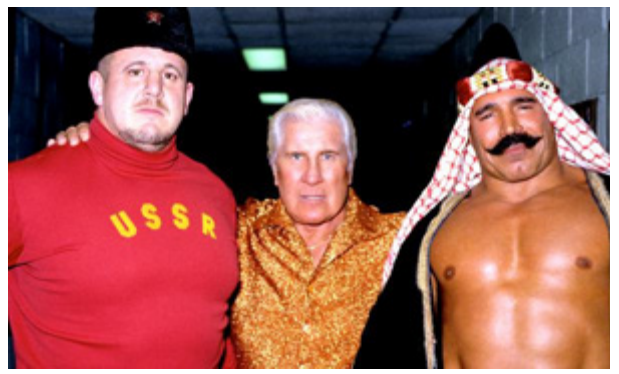

Il. 17. Nikolai Volkoff $i$ The Iron Sheik

Przytoczony powyżej refren utworu towarzyszącego Hulkowi Hoganowi przez większą część jego zapaśniczej kariery dobrze oddaje specyfikę postaci Amerykańskiego Patrioty. To osobnik nade wszystko ceniący sobie honor narodu i dobre imię swojego kraju - ten, który amerykańskie wartości uznaje za nadrzędne i zrobi wszystko, by ich bronić. Stąd też nieuniknione jest jego starcie ze Złym Cudzoziemcem (o którym piszę w dalszej części tekstu).

Swój patriotyzm postać ta manifestuje - zgodnie z wymogiem przejrzystości przekazu - w czynach skonwencjonalizowanych, prostych i uniwersalnie zrozumiałych. Może to być gest salutowania (jako że żołnierze i weterani armii amerykańskiej cieszą się w USA szczególną estymą), pochwała wyznawanych wartości czy też oddanie czci fladze. Ringowy Patriota często nosi także kostium w barwach narodowych lub z charakterystycznym wzorem gwieździstego sztandaru.

\subsubsection{Zły Cudzoziemiec}

Początków tego archetypu należy szukać w powojennej Japonii i pierwszych pokazach puroresu. Zawody te miały wydźwięk silnie nacjonalistyczny, nie uciekały się jednak do karykaturalnego przedstawienia wroga - wedle tradycyjnej narracji źródłem negatywnych emocji była sama narodowość oponenta. W wersji amerykańskiej motyw ten wykorzystuje napięcie geopolityczne jako podłoże konfliktu, z założeniem, że rodzime wartości są wartościami nadrzędnymi. Duma, jaką cudzoziemiec czuje ze względu 
na swoje pochodzenie, nierzadko staje się wystarczającym powodem, by wywołać niechęć amerykańskiego widza. Odpowiadając jednak na postulat wszechobecnego wyolbrzymienia, Zły Cudzoziemiec nie ogranicza się jedynie do chwalenia własnego kraju, koniecznie musi on pogardzać wszystkim, co amerykańskie. Buczącej widowni zarzuca za to ksenofobię i ograniczone horyzonty myślowe.

Wrestling, jako przedstawienie bazujące na projekcji tłumionych pragnień i obaw, opiera narrację na panujących w danym czasie społecznych nastrojach, kolektywnych lękach i współczesnych trendach. Stąd też okres Zimnej Wojny przyniósł postacie krwiożerczych komunistów ${ }^{141}$; niestabilna sytuacja na Bliskim Wschodzie - pogardzającego „zgniłym Zachodem” The Iron Szejka; eskalacja konfliktu w Zatoce Perskiej - niespodziewany heel turn Sierżanta Slaughtera (który nagle odwrócił się od wyznawanych przez siebie patriotycznych wartości i zbratał się z wcześniej wymienionym Szejkiem); a aneksja Krymu przez Federację Rosyjską - wychwalającego rządy Władimira Putina Aleksandra Ruseva (choć stojący za postacią performer, Mirosław Barniaszew, jest Bułgarem) i jego partnerkę Lanę. Wizerunki tychże postaci są oczywiście przerysowane i przesadzone, oparte na stereotypowym postrzeganiu parodiowanych w ten sposób narodowości ${ }^{142}$.

\subsubsection{Komik/Trickster}

Trickster rzadko widywany jest w towarzystwie prestiżowych tytułów mistrzowskich i performerów ze szczytu hierarchii. Jego rola zwykle ogranicza się do lekkich skeczy, slapstickowych żartów i humorystycznych pojedynków będących dla widzów chwilą odpoczynku pomiędzy ważniejszymi,

141 Za postacią Nikolaia Volkoffa, jednego z zawodników wchodzących w skład drużyny o nazwie „Bolszewicy” (jego partnerem drużynowym był amerykański zapaśnik James Kirk Harrell występujący jako Boris Zhukov), kryje się osobista tragedia performera, który odgrywał tę rolę. Choć sama postać wśród kibiców odzwierciedlała ponure widmo komunizmu, Josip Peruzović (1947-2018) - syn Ukrainki i Chorwata, który wcielał się w postać Volkoffa - w 1967 roku wyemigrował z Jugosławii, uciekając przed krwawym reżimem. Dopiero po upadku Związku Radzieckiego w 1991 roku otrzymał zgodę promotora na zmianę wyznawanych przez postać wartości.

142 Zob. część 3.2. Stereotypy rasowe i narodowe. 


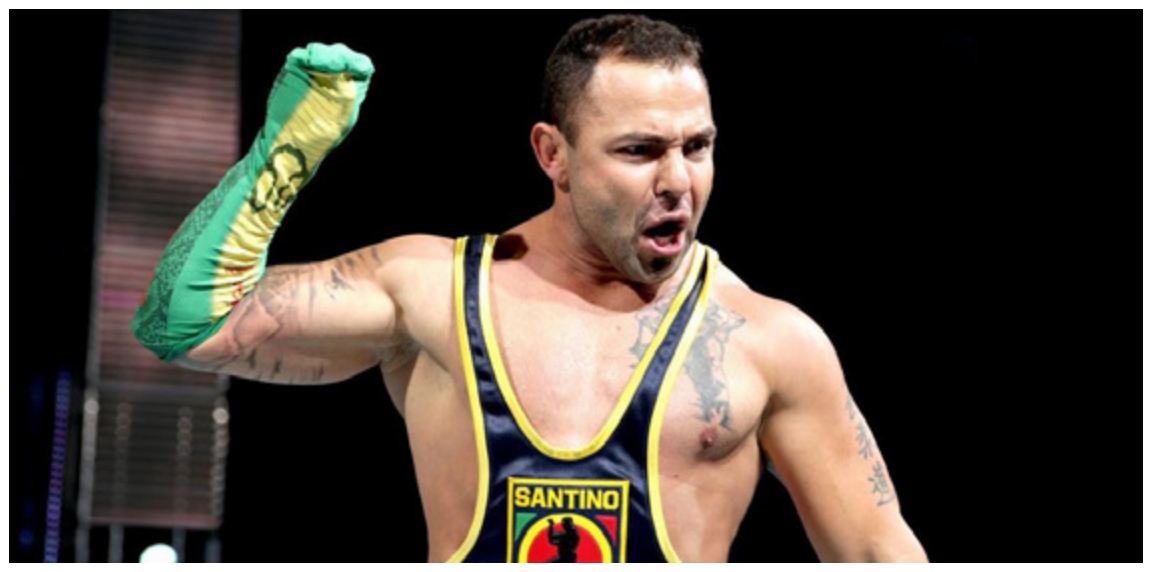

Il. 18. Santino Marella i jego maskotka - kobra

trzymającymi w napięciu i pełnymi emocji starciami największych gwiazd pokazu. Kiedy jednak błazen, wbrew wszelkim oczekiwaniom, zostaje mistrzem, jego narracja staje się opowieścią o Underdogu.

Komik zwykle wyróżnia się na tle pozostałych zawodników ostentacyjnym nieprzystosowaniem do obowiązującego wzorca. Mniej muskularny, chudy lub wręcz przeciwnie - z nadwagą, obły - sprawia wrażenie przybysza „z innego świata" - rzeczywistości nie przerysowanych atletów, a zwykłych ludzi.

\subsubsection{Monster ( $\mathrm{Heel}$ )}

Typ Potwora miano swe otrzymuje ze względu na potężne gabaryty. Wysoki i masywny, obdarzony nieludzką siłą, niszczy wszystko i wszystkich na swojej drodze. Nie musi wiele mówić - przemawia za niego ciało.

Archetyp Potwora (zwyczajowo zwanego Monster Heelem, jako że nieprzeciętne gabaryty najczęściej stanowiły pretekst do kreacji postaci negatywnych) naturalnie wpisuje się w Barthes'owski postulat widowiskowej przesady. Groteskowo wyolbrzymione ciała, będące wynikiem albo intencjonalnie ponadprzeciętnego rozrostu masy mięśniowej, albo schorzenia (gigantyzmu bądź akromegalii ${ }^{143}$ ) - przyciągają uwagę przypadkowych

${ }^{143}$ Cierpiał na nią m.in. André „The Giant”, prawdopodobnie najbardziej znany „gigant” w historii wrestlingu. 
widzów bez konieczności wykorzystywania skomplikowanych skryptów. Mimo ograniczonej sprawności ruchowej (trudno bowiem wyobrazić sobie Potwora wykonującego skomplikowane akrobacje), widok umyślnej destrukcji, jaką sieje, robi wystarczające wrażenie. Postać ta sprawia pozór niezniszczalnej, dlatego też śmiałek, któremu uda się go

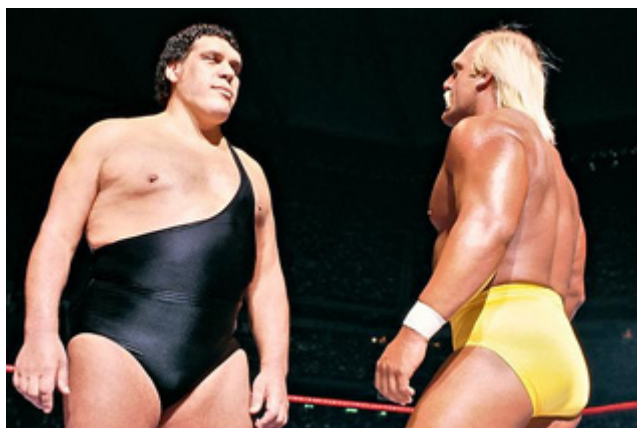

Il. 19. André „The Giant” mierzy się z Hulkiem Hoganem pokonać, natychmiast zyskuje szacunek i podziw w oczach widza.

\section{PRO WRESTLING W KULTURZE POPULARNEJ}

Przez ponad pół wieku pokazy zapasów profesjonalnych znajdowały się na marginesie społecznej świadomości. Amerykańskie organizacje regionalne skupione wokół większych miast regularnie gromadziły wierne grupy miłośników, jednak wciąż daleko im było do miana potęgi. Sytuacja ta zmieniła się w latach 80. XX wieku. Zainteresowanie wrestlingiem terytorialnym gwałtownie wzrosło, a szereg różnych czynników uczynił tę widowiskową dyscyplinę fenomenem na skalę globalną.

\subsection{THE ROCK \& WRESTLING CONNECTION}

W 1982 roku władzę w nowojorskiej federacji World Wide Wrestling Federation przejął od swojego ojca Vincent K. McMahon. Niedługo potem udało mu się zatrudnić wschodzącą gwiazdę zapasów terytorialnych - niespełna trzydziestoletniego Terry'ego Bolleę, występującego pod pseudonimem Hulk Hogan. Już wtedy był on osobistością rozpoznawalną w środowisku zapaśniczym (miał bowiem za sobą występy zarówno w licznych organizacjach amerykańskich, jak i japońskiej NJPW), zaistniał także w świadomości publicznej dzięki 


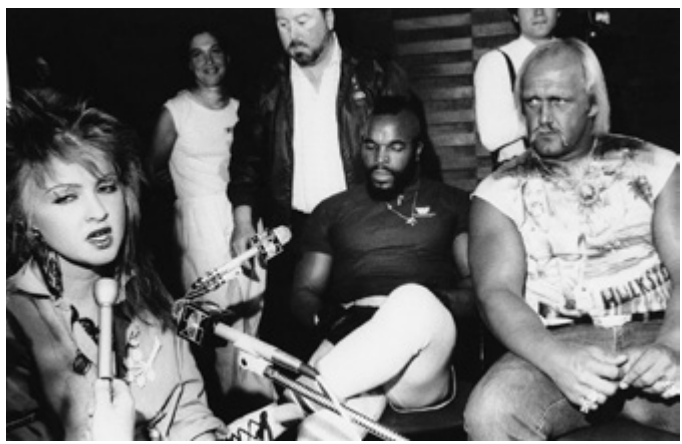

Il. 20. Cyndi Lauper i Mr. T promuja nadchodzacy pokaz

krótkiemu epizodowi u boku Sylvestra Stallone'a w filmie Rocky III ${ }^{144}$.

Postura zawodnika (dwa metry wzrostu i waga około stu trzydziestu kilogramów) okazała się ważnym czynnikiem w wyborze typu prezentowanej przez niego postaci, promowano go bowiem do roli dominującego złoczyńcy - Monster Heela. McMahon dostrzegł jednak wrodzoną charyzmę Hogana i zdecydował się kompletnie zmienić jego charakter. W styczniu 1984 roku Hogan obronił innego popularnego zawodnika - Boba Backlunda - przed atakiem drużyny złoczyńców. Wkrótce potem pokonał The Iron Sheika (wcielającego się w stereotypowo negatywną postać imigranta $\mathrm{z}$ Bliskiego Wschodu) w pojedynku o mistrzostwo federacji. Zabieg ten zapoczątkował ruch zwany Hulkamanią. Hogan, już jako ulubieniec publiczności, nazywał swoich fanów „hulkamaniakami” i „braćmi”, przypominał im też o regularnej gimnastyce, modlitwie i witaminach ${ }^{145}$. Wtedy też przybrał barwy, z którymi do dziś jest utożsamiany - czerwień i żółć.

W tym samym czasie nowo powstała stacja muzyczna MTV szybko zdobywała popularność wśród młodzieży, z każdym miesiącem zwiększając swój zasięg. Dostrzegłszy szansę także dla swojej organizacji, McMahon nawiązał współpracę ze wschodzącą gwiazdą muzyki pop, Cyndi Lauper. Podczas wywiadu prowadzonego przez Roddy'ego Pipera piosenkarka wdała się w kłótnię z „Kapitanem” Lou Albano (który wcześniej wystąpił w teledysku do utworu Girls Just Wanna Have Fun), po czym rzuciła mu wyzwanie - w pojedynku na specjalnym pokazie miały zmierzyć się ze sobą

144 Hogan wcielił się w rolę przeciwnika Rocky'ego Balboa.

145 Powiedzenie Hogana „Train, say your prayers, eat your vitamins” przeszło do historii dyscypliny jako jeden z największych sukcesów marketingowych. Koszulki $z$ tym sloganem sprzedawały się na pokazach w tysiącach egzemplarzy. 
wybrane przez każdą ze stron zawodniczki. Albano wybrał The Fabulous Moolah, weterankę dyscypliny, a przy tym panującą mistrzynię kobiet ${ }^{146}$, Lauper natomiast postawiła na młodą Teksankę, Wendi Richter. Do walki doszło na emitowanym w MTV pokazie The Brawl To End It All w lipcu 1984 roku $^{147}$, a Richter - dzięki interwencji piosenkarki - zwyciężyła starcie.

Zachęcony sukcesem pokazu Vince McMahon postanowił kontynuować współpracę z MTV. Kolejny pokaz specjalny - The War To Settle The Score - zgromadził na trybunach Madison Square Garden dwadzieścia dwa tysiące widzów, a oprócz Cyndi Lauper (towarzyszącej Hulkowi Hoganowi w pojedynku, w którym bronił mistrzostwa WWF) wzięli w nim udział także Mr. T, znany z serialu Drużyna A, i... Andy Warhol.

\subsection{ODWOŁANIA I NAWIĄZANIA W KULTURZE POPULARNEJ}

Dzięki sukcesowi akcji Rock \& Wrestling Connection pro wrestling zaistniał zarówno w świadomości przeciętnego Amerykanina, jak i w mediach głównego nurtu. Przełożyło się to na zmianę charakteru pokazów organizowanych przez WWE - gale przerodziły się z intymnych wydarzeń, skupiających wąską grupę odbiorców, w kolosalne międzybranżowe przedsięwzięcia, przyciągające znane nazwiska z różnych dziedzin sportu i przemysłu rozrywkowego zarówno na trybuny, jak i za kulisy.

\subsubsection{Występy gościnne}

Organizacje głównego nurtu chętnie wykorzystują obecność mniej lub bardziej znanych celebrytów, obsadzając ich w rolach menedżerów, sędziów specjalnych lub gości pokazów, a czasem nawet performerów. Zabiegi te zapewniają zwiększone zainteresowanie mediów i wzajemną promocję projektów, w jakie angażują się obie strony. Mogą to być pojedyncze występy

146 Mistrzostwo kobiet było w posiadaniu Moolah przez przeszło 28 lat. Zdobyła je w 1956 roku, a w latach 70., gdy jej organizacja-matka ogłaszała bankructwo, wykupiła prawa do tytułu, które następnie w 1983 roku odkupił od niej Vince McMahon.

147 Pokaz uzyskał rating 9.0 według agencji Nielsena, co uczyniło go najchętniej oglądanym programem w ówczesnej historii stacji. Choć cała gala z nowojorskiej hali Madison Square Garden została nagrana na potrzeby późniejszej dystrybucji, starcie Moolah i Richter było jedynym wyemitowanym w telewizji pojedynkiem. 


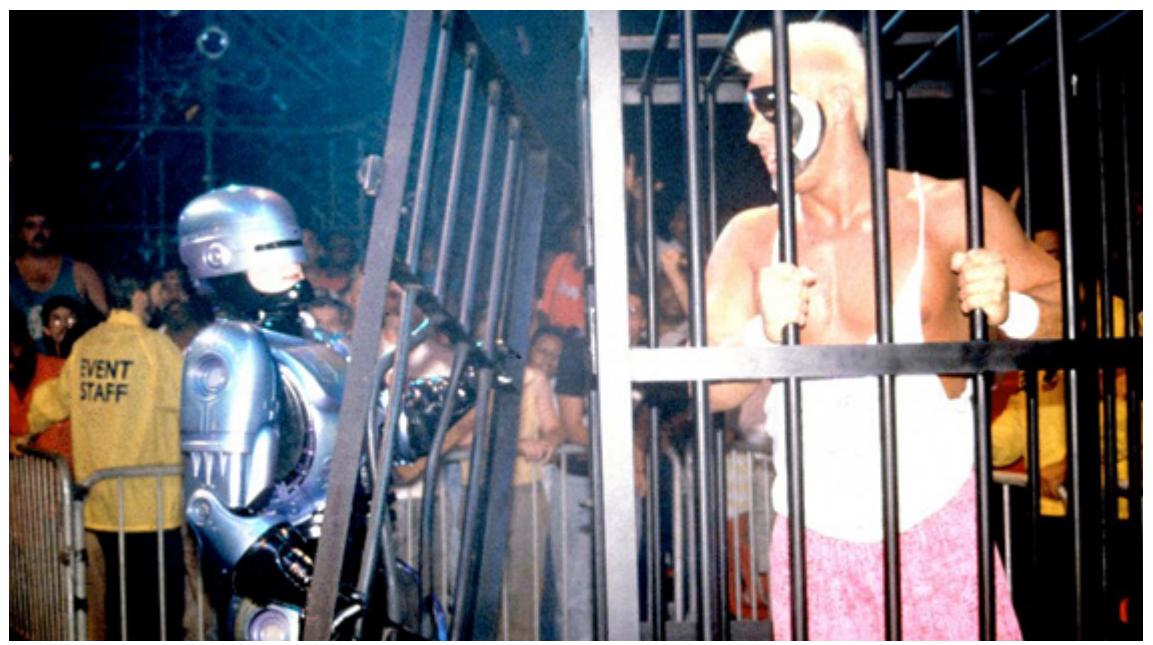

Il. 21. RoboCop ratuje ulubieńca publiczności, Stinga

(wówczas rola gościa ogranicza się najczęściej do pojedynczego skeczu lub interakcji z zawodnikiem) bądź dłuższa współpraca, wymagająca wtajemniczenia w kayfabe i przygotowanie dłuższego scenariusza.

Wspomniany wcześniej Mr. T pojawiał się na pokazach WWF wielokrotnie, czego kulminacją okazał się jego występ w walce wieczoru podczas pierwszej Wrestlemanii. W ten sam pojedynek zaangażowani byli także Muhammad $\mathrm{Ali}^{148}$ (jako drugi sędzia) oraz artysta estradowy Liberace. Ponadto w ringu WWE gościli między innymi: bokser Mike Tyson (zaangażowany w walkę wieczoru podczas Wrestlemanii XIV), Pamela Anderson, Fred Durst - wokalista zespołu Limp Bizkit (który, podobnie jak Mike Tyson, pojawił się również w licencjonowanych grach wideo organizacji), komik Drew Carey czy też baseballista Pete Rose. Porządku podczas walki wieczoru Survivor Series 1994 pilnował Chuck Norris, Burt Reynolds gościnnie zapowiedział uczestników głównego starcia Wrestlemanii X, koszykarz Shaquille O’Neil mierzył się z naczelnym gigantem WWE - The Big Showem, a Donald Trump - przyszły prezydent Stanów Zjednoczonych -

148 Nie był to pierwszy kontakt słynnego boksera ze światem pro wrestlingu. W 1976 roku w tokijskiej hali Nippon Budokan odbył on bowiem pojedynek z pionierem puroresu, Antonio Inokiem. 
ogolił głowę samego prezesa organizacji podczas dwudziestej trzeciej edycji wielkiego show.

Także konkurencyjna federacja - WCW - chętnie posiłkowała się obecnością gwiazd i celebrytów. W ringu Teda Turnera stałym gościem był kontrowersyjny koszykarz Dennis Rodman, okazjonalnie pojawiali się także chociażby Jean-Claude Van Damme,

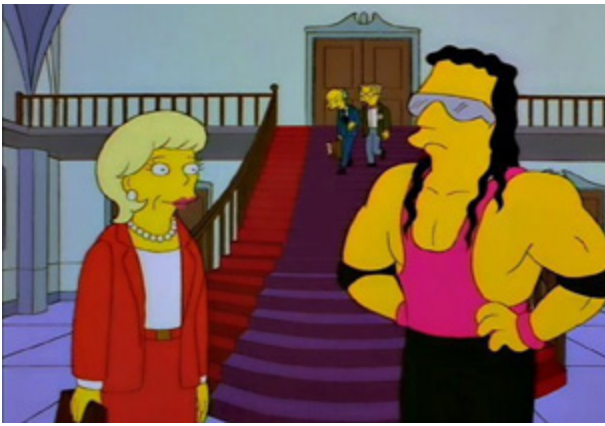

Il. 22. Bret „The Hitman” Hart w odcinku serialu Simpsonowie Chuck Norris czy James Brown.

Znany z serii filmów Krzyk aktor David Arquette przez krótki czas był nawet mistrzem wagi ciężkiej organizacji (zabieg ten miał pomóc wypromować film Kibice do dzieła!, wyprodukowany we współpracy z WCW). Scenarzyści nie ograniczali się jednakże wyłącznie do realnych celebrytów - gościnne występy zaliczyły tu również postacie fikcyjne, w tym RoboCop i laleczka Chucky.

Udział znanych ludzi nie był przy tym domeną wyłącznie organizacji głównego nurtu. Dobrze udokumentowana została również rywalizacja popularnego komika Andy'ego Kaufmana z promotorem terytorialnym z Memphis, „Królem” Jerrym Lawlerem. Wątek ten uwieczniony został także w filmie Miloša Formana Człowiek z księżyca.

Współpraca między różnymi gałęziami show biznesu nie ogranicza się także wyłącznie do gościnnych występów w ramach pokazów pro wrestlingu. Największe gwiazdy dyscypliny, takie jak Hulk Hogan, „Macho Man” Randy Savage czy Bret Hart, doczekały się statusu ikon amerykańskiej popkultury, a wydarzenia i wizerunki szczególnie widowiskowe wielokrotnie były parodiowane i trawestowane w tekstach kultury popularnej.

\subsection{SPORTOWIEC CZY CELEBRYTA?}

Nie tylko ciała postaci zostają utowarowione, towarem stają się także sami performerzy. Ci najpopularniejsi, zyskując status celebryty, nierzadko rezygnują z komfortu prywatności na rzecz życia w świetle reflektorów. Rozwijają karierę w przemyśle rozrywkowym, pieczołowicie pielęgnując własną markę personalną. 
Naturalnym rozszerzeniem kariery pro wrestlera wydaje się aktorstwo. Wielu performerów próbowało swoich sił w Fabryce Snów z różnym skutkiem - wszak filmy, w których zagrał chociażby Hulk Hogan (takie jak seria Grom w raju, Pan Niania czy Muskularny Święty Mikołaj), trudno uznać za projekty ambitne. Rozpoznawalny wizerunek i nazwisko nierzadko jednak wystarczą, by producenci i reżyserzy gotowi byli zatrudnić byłych bądź obecnych zapaśników. Sukcesy, jakie odnoszą w Hollywood Dave Bautista (zaangażowany między innymi w ciepło przyjętą zarówno przez krytyków, jak i widzów serię Strażnicy Galaktyki) czy Dwayne „The Rock” Johnson (najlepiej zarabiający aktor 2016 roku według magazynu „Forbes”), pozwalają przewidywać, iż trend ten będzie trwał.

Nieco mniej wymagającą, a przy tym łatwiejszą w dystrybucji formą utrzymania zainteresowania wokół własnej persony jest produkcja programów typu reality show - fabularyzowanych i udramatyzowanych treści symulujących życie prywatne swoich bohaterów. Postacie, podobnie jak sceniczne persony zawodników, są groteskowo przesadzone, a problemy, z którymi muszą się zmierzyć - wyolbrzymione. Wyniki oglądalności poszczególnych programów świadczą jednak o niesłabnącym popycie na tego typu treści. Wyprodukowany dla stacji VH1 Uparty jak Hogan gościł na antenie przez cztery sezony, WWE Tough Enough, program mający na celu wyłonienie przyszłych gwiazd branży - sześć sezonów, z kolei współtworzone przez WWE i stację E! Entertainment serie Total Divas i Total Bellas - łącznie dziewięć sezonów ${ }^{149}$.

Nie jest to jednak jedyny sposób na promowanie własnej osoby. Niektórzy performerzy-celebryci próbują swoich sił w muzyce (swoje zespoły założyli między innymi Chris Jericho i Amy „Lita” Dumas), modelingu (jak Stacy Keibler i Torrie Wilson, menedżerki popularne na przełomie wieków) lub innych sportach walki, np. MMA (w pojedynkach większych organizacji, takich jak UFC i Bellator, brali udział między innymi Brock Lesnar, Bobby Lashley i CM Punk). Częstą praktyką jest również dystrybucja gadżetów sygnowanych własnym nazwiskiem; przykładowo, bliźniaczki Bella założyły markę Birdie Bee, pod którą kryje się ekskluzywna bielizna, natomiast „Stone Cold” Steve Austin wypromował własną markę piwa - Broken Skull.

149 Stan na sierpień 2017 roku. 


\subsubsection{El Santo}

Marki personalne i osobisty branding nie są jednak wyłączną domeną amerykańskiego przemysłu rozrywkowego, a popularność, jaką ciszą się obecni performerzy-celebryci, nie może równać się ze sławą, jaką w drugiej połowie XX wieku osiągnął niepozorny luchador w srebrnej masce.

Alter ego Rodolfo Guzmána Huerty - El Santo („Święty”) - powstało na początku lat 40. XX wieku. Wizerunek ten zaproponował ówczesny promotor i przyjaciel zawodnika. Tradycyjny, skromny strój (jasne spodnie i srebrna maska) stały się znakiem rozpoznawczym bohatera, a wraz ze wzrostem popularności zapaśnika jego wizerunek zaczął pojawiać się nie tylko na plakatach zwiastujących kolejne pojedynki, ale i w tekstach kultury popularnej. W 1951 roku powstał pierwszy cykl komiksów, których głównym bohaterem był właśnie Santo. Kilka lat później do kin weszły pierwsze filmy o niezwykłych przygodach prawego luchadora: Santo contra El cerebro del mal („Santo kontra złowrogi mózg”), Santo contra los zombies („Santo kontra zombie”) czy Santo contra las mujeres vampiro („Santo kontra wampirzyce”). Produkcje te, utrzymane w konwencji „potwora tygodnia”, przedstawiały zapaśnika jako niepokonanego herosa, superbohatera dzielnie zwalczającego zło, niezdejmującego maski nawet do snu ${ }^{150}$.

Mit Santo nie ograniczał się jednak do czczej rozrywki dla mas. Choć produkcje nurtu cine de lucha libre, jak zauważa Bolesław Racięski, postrzegane były jako przejaw kryzysu meksykańskiej kinematografii, wytwory wręcz kiczowate, niosły one ze sobą przekaz społeczny, zaś sam Santo stał się swoistym idolem-pedagogiem - uczył pokory (jako że zło zwalczał anonimowo, nie odsłaniając twarzy) i wierności (sprzeciwiając się tym samym wzorcowi macho - rozbuchanego seksualnie „kolekcjonera” kobiet); przekonywał zarówno do nowoczesnych technologii, jak i zachowania pierwiastka ludowej duchowości ${ }^{151}$. Podobnie jak amerykański Bohater Klasy Robotniczej, Santo był bohaterem marginalizowanych grup społecznych (clases subalternas), i to do nich kierowany był związany z nim przekaz.

150 B. Racięski, Zapaśnik bawi i uczy. Społeczne funkcje filmów o Santo, [w:] Bękarty kinematografii, czyli rzecz o filmach nie(do)cenionych, red. B. Racięski, J. Łuniewicz, F. Nowak, Wrocław 2014, s. 114.

151 Ibidem, s. 118. 
Santo kontynuował karierę do 1984 roku, aż do końca występując zarówno w ringu, jak i na ekranie (luchador zagrał łącznie w przeszło pięćdziesięciu filmach). Do końca życia udało mu się także zachować tajemniczą aurę wokół swojej postaci. Tylko raz odsłonił publicznie swoją twarz - tydzień później zmarł.

\section{PRO WRESTLING W POLSCE}

Choć na świecie wrestling od lat cieszy się niesłabnącym zainteresowaniem, w Polsce wciąż pozostaje zjawiskiem niszowym, skupiającym wokół siebie relatywnie niewielką liczbę miłośników. Od kilku lat można jednak zauważyć stopniowy wzrost aktywności społeczności fanowskiej, przejawiający się nie tylko wzmożoną dyskusją w przestrzeni wirtualnej, ale i różnymi formami samoorganizacji poza nią. Powstają pierwsze organizacje - zarówno profesjonalne, jak i amatorskie (w środowiskowym żargonie zwane „backyardowymi”), a entuzjaści rozrywki sportowej aktywnie szukają sposobów, by prowadzić treningi w swej ulubionej dyscyplinie - nierzadko na własną rękę.

\subsection{ZAPASY PROFESJONALNE W TELEWIZJI}

Polscy amatorzy profesjonalnych zapasów mogą oglądać przede wszystkim audycje oferowane przez giganta branży, federację World Wrestling Entertainment. Programy produkowane przez tę organizację emituje rodzimy oddział stacji Extreme Sports Channel ${ }^{152}$, specjalizującej się - jak zresztą sugeruje nazwa - w sportach ekstremalnych ${ }^{153}$. Jest to kanał ogól-

${ }^{152}$ Nie jest to jednak pierwszy przypadek emisji profesjonalnego wrestlingu w polskiej telewizji. Już w latach 1998-2001 wchodzące w skład pakietu telewizji cyfrowej Wizja TV stacje Wizja Jeden i Wizja Sport nadawały zarówno cotygodniowe pokazy WWF Superstars (komentowane m.in. przez medalistę olimpijskiego Andrzeja Suprona), jak i wykonaną techniką claymation animowaną parodię walk z udziałem celebrytów zatytułowaną Celebrity Deathmatch, której nazwę na język polski przetłumaczono jako Zapasy na śmierć $i \dot{z} y c i e$. Także stacja Polsat emitowała program konkurencyjnej względem WWF organizacji - WCW Worldwide.

153 Poza wrestlingiem w ramówce stacji znajdują się między innymi audycje poświęcone sportom motorowym (w tym motocrossowi), jeździe wyczynowej na rowerach typu BMX, snowboardowi, surfingowi, skateboardingowi, a także 
nodostępny, znajdujący się zarówno w ofercie sieci kablowych, jak i w podstawowych pakietach platform cyfrowych.

W ramówce Extreme Sports Channel wrestling obecny jest od 2007 roku $^{154}$ - wtedy to stacja rozpoczęła emisję cotygodniowej audycji o nazwie $W W E R a w^{155}$. Jeszcze w tym samym roku wykupione zostały prawa do emisji kolejnej „tygodniówki” WWE o nazwie Smackdown. Programy te różniły się jednak od wersji przeznaczonych dla widza amerykańskiego, które trwały po sto dwadzieścia minut każda ${ }^{156}$, podczas gdy wariant przeznaczony do międzynarodowej dystrybucji był w istocie czterdziestopięciominutowym skrótem kluczowych dla fabuły wydarzeń, w dodatku prezentowanym z miesięcznym opóźnieniem względem pierwotnej transmisji w Stanach Zjednoczonych.

Stacja sukcesywnie rozwijała ofertę, w styczniu 2010 roku wprowadzając do ramówki kolejną audycję - nieistniejące już $E C W^{157}$, a także comiesięczne pokazy specjalne ${ }^{158}$, tak zwane PPV $^{159}$. W 2013 roku rozszerzono ofertę

zyskującym w ostatnich latach na popularności mieszanym sztukom walki (w skrócie: MMA).

154 http://www.wrestling.pl/wrestling-w-tv.html, [dostęp: 10.01.2017].

155 Program ten uznawany jest za najważniejszą „tygodniówkę” federacji WWE. Jest także najstarszy - nadawany nieprzerwanie od 11 stycznia 1993 roku, liczy sobie obecnie ponad 1200 odcinków.

156 Obecnie czas emisji Raw to 180 minut.

157 Program ten był próbą przywrócenia treści oferowanych przed laty przez federację o tej samej nazwie (Extreme Championship Wrestling), wykupionej w 2001 roku przez rodzinę McMahonów. Charakteryzował się wysokim stopniem zróżnicowania (w pokazach brali udział m.in. meksykańscy luchadorzy i mistrzowie puroresu) i zwiększoną częstotliwością brutalnych pojedynków typu hardcore. Ze względu na skargi inwestorów program najpierw ocenzurowano, a potem zaprzestano jego produkcji. Ostatni odcinek WWE ECW wyemitowano 16 lutego 2010 roku, zastępując go NXT skupionym na promocji młodych zawodników.

158 http://wrestlefans.pl/forum/viewtopic.php?t=10014, [dostęp: 10.01.2017].

159 Jest to skrót od pay-per-view, określenia oznaczającego płatną usługę transmisyjną. W przeciwieństwie do wielu zagranicznych nadawców, Extreme Sports Channel emituje te gale w ramach standardowej ramówki, bez dodatkowych opłat. 
o kolejną audycję - Main Event ${ }^{160}$, zmniejszono także opóźnienie emisji z czterech do dwóch tygodni. W marcu 2017 roku poinformowano o zmniejszeniu opóźnienia o kolejny tydzień ${ }^{161}$. Obecnie polscy fani pro wrestlingu mogą legalnie i bezpłatnie oglądać zdecydowaną większość treści produkowanych przez WWE zaledwie kilka dni po amerykańskiej premierze. Materiały te są przetłumaczone na język polski i opatrzone komentarzem Andrzeja Suprona (wicemistrza olimpijskiego w zapasach klasycznych) i Pawła „Boryssa” Borkowskiego (założyciela portalu Wrestlefans.pl, wieloletniego miłośnika pro wrestlingu i propagatora tej dyscypliny w Polsce). Od lutego 2014 roku mogą także wykupić subskrypcję WWE Network - serwisu $\mathrm{VOD}^{162}$ oferującego nieograniczony dostęp zarówno do aktualnych „tygodniówek” oraz pokazów specjalnych, jak i bogatej biblioteki plików, w tym pokazów archiwalnych, filmów dokumentalnych i fabularnych tworzonych przez podległe organizacji studio filmowe WWE Studios, wywiadów oraz programów luźno związanych z samym wrestlingiem, wyprodukowanych na potrzeby platformy. Organizacja nie podaje jednak, ile osób skorzystało z tej możliwości.

Stałe rozwijanie oferty adresowanej do miłośników zapasów wynika z ciągle rosnącego zainteresowania tą dyscypliną - od samego początku programy związane z pro wrestlingiem należały do najchętniej wybieranych punktów ramówki i od lat zajmują najwyższe pozycje w corocznych podsumowaniach oglądalności. Według badań AGB Nielsen Media Research, przeprowadzonych w latach 2008-2009, WWE Raw było na wspomnianym kanale drugim najchętniej oglądanym programem, gromadzącym przed ekranami średnio osiemdziesiąt tysięcy widzów ${ }^{163}$. Rok później programy federacji Vince’a McMahona zdominowały pierwszą piątkę rankingu z wynikami: 145 tysięcy (ECW, pierwsze miejsce), 130 tysięcy (Smackdown, drugie miejsce), 116 tysięcy (Raw, trzecie miejsce) i 97 tysięcy widzów (NXT, miejsce

160 http://satkurier.pl/news/82033/extreme-sports-channel-z-wwe-main-event. html, [dostęp: 10.01.2017].

${ }^{161} \mathrm{http}: / /$ wrestlefans.pl/index.php?news_action=more\&newsid=79, [dostęp: 25.03.2017].

162 Ang. video on demand („wideo na żądanie”).

163 http://www.wrestling.pl/news-ogladalnosc-wwe-raw-w-polsce.html [dostęp: 10.01.2017]. 
piąte) ${ }^{164}$. W kolejnych latach oglądalność programów World Wrestling Entertainment sukcesywnie rosła, osiągając rekordowe (jak na skalę stacji) wyniki - kolejno: 171 tysięcy widzów w roku 2011 (NXT) ${ }^{165}$ i 188 tysięcy w roku 2012 (gala PPV Survivor Series) ${ }^{166}$. Średnia widownia utrzymuje się na poziomie około stu czterdziestu tysięcy widzów ${ }^{167}$.

Extreme Sports Channel nie jest jedynym kanałem, który posiadał w swojej ramówce treści związane z wrestlingiem. Do 2013 roku także Eurosport proponował poniedziałkowe pasmo, podczas którego nadawany był nie tylko skrót (niemalże telegraficzny) wydarzeń minionego tygodnia, ale i Vintage Collection - archiwalne pojedynki pozwalające młodszym widzom zapoznać się z historią dyscypliny. Pasmo uzupełniały krótkie wywiady z zawodnikami i zawodniczkami. Ogólnopolska stacja TV Puls prezentowała z kolei program WWE Superstars w ramach piątkowego "pasma mocnych wrażen" ${ }^{\prime \prime 68}$. Ze względu na skargi dotyczące rzekomej brutalności treści (zdaniem wielu internautów - bezzasadne), audycję najpierw przesunięto na późniejszą, mniej korzystną godzinę, a następnie zrezygnowano z jej nadawania - prawdopodobnie ze względu na niespełniającą oczekiwań oglądalność.

Krótkoterminowe kontrakty z polskimi dostawcami podpisała także federacja TNA/Impact Wrestling. Kilka odcinków programu wyemitowała w 2006 roku stacja Eurosport, a w latach 2012-2014 pokazy tejże organizacji nadawane były na kanale Orange Sport. W obu przypadkach audycje zniknęły $z$ anteny bez podania przyczyny.

\subsection{ZAPASY PROFESJONALNE NA ŻYWO}

Naturalną konsekwencją zadowalających wyników oglądalności okazała się decyzja o zorganizowaniu na terenie Polski pokazów zapaśniczych na

164 http://www.wrestling.pl/news-ogladalnosc-wwe-w-polsce-extreme-sports. html [dostęp: 10.01.2017].

165 http://www.wrestling.pl/news-ogladalnosc-wwe-w-polsce-od-listopada-do. html [dostęp: 10.01.2017].

166 http://www.wrestling.pl/news-ogladalnosc-wwe-w-polsce-od-listopada2011-do.html [dostęp: 10.01.2017].

167 Ibidem.

168 http://www.wirtualnemedia.pl/artykul/jerry-springer-show-i-wrestling-wiosna-w-tv-puls/ [dostęp: 26.02.2017]. 
żywo, tak zwanych live events. W ramach europejskiej trasy zawodnicy WWE odwiedzili kraj nad Wisłą czterokrotnie. W listopadzie 2011 roku i kwietniu 2012 roku show odbyło się w gdańskiej Ergo Arenie, w kwietniu 2013 roku pokaz urządzono w łódzkiej Atlas Arenie, natomiast w kwietniu 2015 roku galę zorganizowano w warszawskiej Hali Torwar. Największym zainteresowaniem cieszył się pierwszy pokaz, na który sprzedano ponad dziesięć tysięcy biletów ${ }^{169}$. Kolejne zgromadziły mniejszą liczbę chętnych, osiągając wyniki kolejno: siedem tysięcy ${ }^{170}$, trzy i pół tysiąca ${ }^{171}$ oraz pięć tysięcy nabytych wejściówek ${ }^{172}$. Można wysnuć wniosek, iż pierwszy tego typu pokaz przyciągnął wielu przypadkowych odbiorców, ciekawych niecodziennej formy rozrywki, podczas gdy wejściówki na następne edycje zakupili przede wszystkim zagorzali miłośnicy pro wrestlingu. Należy wziąć pod uwagę także dość wysoki koszt udziału w pokazie ${ }^{173}$ - nie powinien więc dziwić fakt, iż dwuletnia przerwa pomiędzy eventem łódzkim i warszawskim korzystnie wpłynęła na wyniki sprzedaży.

\subsection{FANOWSKA SPOŁECZNOŚĆ INTERNETOWA}

Niezwykle istotne dla integracji środowiska fanowskiego okazuje się medium internetowe. Polscy miłośnicy pro wrestlingu skupieni są przede wszystkim wokół trzech forów dyskusyjnych: Attitude Wrestling Forum, BGŻ Wrestling oraz Forum Wrestlefans. Dwa (Attitude i Wrestlefans) połączone są z dużymi portalami o tej samej tematyce, podczas gdy BGŻ stanowiło jednostkę autonomiczną, mogło także pochwalić się największą bazą zarejestrowanych użytkowników (nieco ponad 14 tysięcy ${ }^{174}$ ). Na drugie co

169 http://www.wrestlinginc.com/wi/news/2011/1117/546751/reby-sky/ [dostęp: 20.02.2017].

170 http://www.wrestlinginc.com/wi/news/2012/0420/551919/ [dostęp: 20.02.2017].

171 http://www.wrestlinginc.com/wi/news/2013/0502/562426/recent-wwe-attendance-figures/ [dostęp: 20.02.2017]

172 Por. http://www.wwe.com/worldwide/wwe-live-event-in-warsaw-poland-april-2015-photos\#fid-27245596 [dostęp: 22.02.2017].

173 Ceny biletów, zależnie od wynajmowanego obiektu i wybranego sektora, wahały się od 55 do 599 złotych.

174 https:// http://bgz-wrestling.pl/ [dostęp: 20.01.2017]. W 2018 roku forum BGŻ zostało wyłączone. 
do wielkości forum - Attitude - zarejestrowało się ponad 10 tysięcy osób ${ }^{175}$, podczas gdy baza Wrestlefans liczy sobie 7,5 tysiąca ${ }^{176}$ użytkowników ${ }^{177}$.

Liczby te jednak nie znajdują odbicia w statystykach ruchu na poszczególnych witrynach. Najaktywniejsi okazują się użytkownicy Attitude - od założenia strony w 2003 roku napisali oni ponad czterysta dwadzieścia tysięcy postów w czterdziestu czterech tysiącach tematów. Członkowie założonego w 2006 roku forum Wrestlefans sformułowali dwieście sześćdziesiąt tysięcy postów w dwudziestu puęciu tysiącach tematów, podczas gdy powstałe w 2005 roku BGŻ zgromadziło jedynie sto sześćdziesiąt tysięcy postów w dwudziestu tysiącach tematów. Największą popularnością cieszą się wątki związane z organizacją WWE, na co bezpośredni wpływ ma zapewne łatwość dostępu do jej oferty programowej. Dość duże zainteresowanie wzbudzają także quizy wiedzy i zabawy, w tym tak zwane typery - gry polegające na przewidywaniu wyników walk. Moderatorzy witryn prowadzą nawet szczegółowe rankingi najskuteczniejszych graczy.

Użytkownicy bardzo chętnie dzielą się także własną twórczością, niekoniecznie związaną z samym pro wrestlingiem. W przeznaczonym do tego celu zakątku witryny zakładają minigalerie, w których prezentują swoje prace graficzne, rysunki, fanarty, a nawet krótkie opowiadania i wiersze. Niezwykle popularną formą twórczości jest tak zwany fantasy booking, w ramach którego członkowie mogą wcielić się w rolę promotora i zarządzać własną federacją. Zainteresowani sami dobierają szczegółowy roster, w skład którego wchodzą zarówno zawodnicy i zawodniczki, którzy będą pojawiać się na pokazach, jak i skład komentatorski, prowadzący, a nawet - jeśli uznają to za konieczne - konkretni sędziowie. Nie ograniczają się w tym jednak tylko do postaci autentycznych; choć większość uczestników tej zabawy preferuje rzeczywistych performerów, w ramach własnej twórczości tworząc ich alternatywne losy, niektórzy decydują się na rozwiązania niestandardowe, na przykład wymyślając fikcyjnych wrestlerów lub w roli zawodników stawiając

175 http://forum.wrestling.pl/ [dostęp: 20.01.2017].

$176 \mathrm{http}: / /$ wrestlefans.pl/forum/index.php [dostęp: 20.01.2017].

177 Są to dane czysto orientacyjne, należy bowiem pamiętać o istnieniu tak zwanych multikont - wielu kontach zakładanych przez jednego użytkownika, a także o kontach nieaktywnych lub zakładanych na poczet jednorazowej wizyty na stronie. 
użytkowników forum. Następnie prowadzą tak zwany diary, w którym planują rywalizacje, piszą scenariusze pokazów, opisują walki, a także decydują o przyznaniu wirtualnych tytułów mistrzowskich.

Podobną, nieco bardziej rozbudowaną formą internetowej gry tekstowej są tak zwane e-fedy ${ }^{178}$ i PBF-y ${ }^{179}$. Są to najczęściej autonomiczne fora internetowe, swoją strukturą imitujące działania prawdziwych organizacji prowrestlingowych. Gracze tworzą własnego zawodnika w dziale zapisów, wypełniając tak zwaną kartę postaci. Analogicznie do przypadku fantasy booking najczęstszą praktyką jest korzystanie z bazy istniejących w rzeczywistości performerów, choć zdarzają się także przypadki postaci wymyślanych od podstaw. Wówczas gracz w ramach karty postaci sam komponuje styl walki, cechy charakteru, reprezentatywne elementy gimmicku (np. strój czy też towarzyszącą wejściu na wirtualny ring muzykę), a także dystynktywne fragmenty choreografii w postaci unikatowych akcji kończących (finisherów) i signature moves.

Po zaakceptowaniu zapisu przez moderatora gracz może przystąpić do zabawy, różniącej się w zależności od typu forum. W przypadku e-fedu uczestnicy ograniczają się jedynie do pisania przemówień (tak zwanych promo) swojej postaci, w których odnoszą się do ogólnej sytuacji w wirtualnej federacji lub zwracają się bezpośrednio do konkretnych graczy, nakreślając potencjalne bądź istniejące już rywalizacje. Wirtualne pokazy pisane są przez specjalnie wyznaczonych użytkowników (tak zwanych writerów) lub symulowane komputerowo za pomocą gry wideo ${ }^{180}$ (wówczas administrator rozgrywa wirtualny pojedynek, nagrywając go za pomocą specjalnego oprogramowania, a następnie udostępnia krótkie filmy na darmowym hostingu najczęściej jest to platforma YouTube). Szeregowi gracze nie mają wpływu na sam pokaz. W przypadku gier typu PBF gracze wypełniają zadania, które wyznacza im mistrz gry wcielający się w rolę promotora. Najczęściej jest to inscenizacja pojedynku pomiędzy dwójką lub większą liczbą graczy. Wówczas uczestnicy opisują zachowanie swoich postaci i projektują choreografię, a porządku pilnuje moderator wcielający się w rolę sędziego; to

178 Skrót od słowa „e-federacja”.

179 Ang. play-by-forum („gra przez forum”).

180 Większość gier wideo o tematyce pro wrestlingu zawiera opcję tworzenia własnego wrestlera od podstaw, co umożliwia administratorom wizualizację także postaci wymyślonych przez graczy. 
on decyduje także o wyniku pojedynku. Do zadań, jakie może wyznaczyć mistrz gry, należy także między innymi: napisanie przemówienia, krótkiego wywiadu czy też scenki rozgrywającej się w ustalonych okolicznościach. $\mathrm{Na}$ forach tego typu funkcjonują również wyróżnienia - wirtualne pasy mistrzowskie i inne tytuły. $\mathrm{O}$ ich przyznawaniu decydują mistrzowie gry i moderatorzy w zależności od zaangażowania i umiejętności graczy.

Internetowej społeczności fanów pro wrestlingu lepiej pozwalają przyjrzeć się statystyki prowadzone przez forum Attitude ${ }^{181}$. Pokazują one, iż większe grupy entuzjastów skupione są przede wszystkim w dużych miastach. Do najczęściej wskazywanych lokacji należą: Warszawa (112 użytkowników), Poznań (71), Kraków (68), Gdańsk (63), Wrocław (61), Szczecin (57) i Białystok (47). Widżet „mapa fanów wrestlingu” dostępny na tejże stronie ${ }^{182}$ pokazuje także gęste skupisko znaczników zlokalizowanych na terenie województwa śląskiego (ze szczególnym udziałem Katowic i okolic). Dane statystyczne, choć skromne, pozwalają stworzyć orientacyjny profil użytkowników forum. Są to z reguły ludzie młodzi (średnia wieku uży tkowników to dwadzieścia siedem i pół roku), przeważnie mężczyźni (stanowią oni co najmniej $45 \%$ wszystkich użytkowników witryny; kobiety - co najmniej 2\%; 53\% spośród dziesięciu tysięcy użytkowników zdecydowało się bowiem nie ujawniać swojej płci). Dane te znacznie różnią się od statystyki dotyczącej demografii ogólnoświatowej bazy fanowskiej pro wrestlingu zaprezentowanej na portalu DDT Digest ${ }^{183}$. Te wskazują z kolei na zdecydowanie większy udział żeńskiej części publiczności; kobiety stanowią tu $37 \%$ ogółu fanbazy i ponad połowę (56\%) korzystających z płatnego modelu pay-per-view.

Warto także zwrócić uwagę na rażącą dysproporcję aktywności użytkowników forum. Statystyki pokazują bowiem, że zaledwie dziesięciu najaktywniejszych $\mathrm{z}$ nich odpowiedzialnych jest za ponad 15\% umieszczonych nań treści. Świadczy to o małym stopniu zaangażowania znacznej części społeczności. Choć na forum codziennie loguje się około czterystu osób, większość ogranicza się do biernego przeglądania treści, nie angażując się w dyskusję.

181 Por. http://forum.wrestling.pl/statistics.php [dostęp: 21.02.2017].

182 Aplikacja automatycznie oznacza użytkowników na mapie Polski, wykorzystując geolokalizację satelitarną.

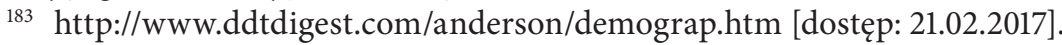


Chociaż dane statystyczno-demograficzne dotyczą raptem jednego $\mathrm{z}$ trzech największych portali (dane zebrane przez administratorów forum Wrestlefans odnoszą się jedynie do częstotliwości publikowania postów w poszczególnych miesiącach, natomiast portal BGŻ Wrestling w ogóle takich danych nie publikuje), analiza treści dyskusji i samej zawartości forów pozwala na charakterystykę członków internetowej społeczności fanowskiej. Jest to, jak już wcześniej wspomniałam, środowisko silnie zmaskulinizowane i młode, świadome konwencji, strategii narracyjno-fabularnych i reguł, jakimi rządzi się pro wrestling (nowi użytkownicy, którym kayfabe jest obcy, bardzo szybko zostają przez innych członków społeczności „wtajemniczeni”). Na forach pogłębiają swoją wiedzę, interesują się historią dyscypliny (bardzo chętnie sięgają po nagrania archiwalne), starają się też - wykorzystując wiedzę dotyczącą schematów narracyjnych i układu sił za kulisami danej organizacji - przewidywać wyniki walk lub kierunek, w którym rozwiną się poszczególne rywalizacje.

Swoje horyzonty poszerzają, tworząc własną publicystykę dotyczącą ulubionej dyscypliny, tłumacząc fragmenty obcojęzycznych książek, a także dzieląc się ze sobą trudno dostępnymi materiałami (np. nagraniami archiwalnymi lub niedostępnymi dla „zwykłego” widza - chociażby pokazami japońskiego puroresu lub meksykańskiego lucha libre). Użytkownicy ci wpisują się w definicję żargonowego określenia smart mark, oznaczającego widza świadomego, krytycznego wobec konsumowanych treści.

\subsection{POLSKIE ORGANIZACJE PROWRESTLINGOWE}

Nie da się ukryć, że pro wrestling w Polsce jest obszarem niszowym; mimo to jego miłośnicy doczekali się powstania pierwszych profesjonalnych organizacji, a także szkółek treningowych, w których chętni mogą uczyć się pod okiem profesjonalistów. Obecnie działają dwie organizacje - Maniac Zone Wrestling oraz Kombat Pro Wrestling.

\subsubsection{Organizacje amatorskie}

Fundament pod powstanie profesjonalnych organizacji położyły jednak kluby amatorskie, w żargonie określane mianem „backyardowych”"184.

184 Nazwa ta pochodzi od angielskiego słowa „backyard” ('podwórko') i w dużej mierze związana jest z realiami tego typu „organizacji”. Ring, jeśli dany klub go 
Na PSW - Polską Scenę Wrestlingu (jak określa się zarówno społeczność internetową, jak i wszelkie formy samoorganizacji) - składają się dziesiątki niewielkich (nierzadko nawet kilkuosobowych) klubów sportowych $i$ amatorskich grupek pasjonatów rozsianych po różnych zakątkach kraju. Do najbardziej znanych należą:

- WSW - Wrocławska Scena Wrestlingu - najstarsza grupa backyardowa w Polsce. Jej początki sięgają 2008 roku. Nie dysponowała ringiem; pokazy odbywały się bez udziału publiczności i nagrywane były w hali gimnastycznej. Walki rozgrywano na materacach, za narożniki służyły natomiast kozły gimnastyczne. Pokazy publikowane były w serwisie YouTube i charakteryzowało je lekkie, humorystyczne podejście do dyscypliny. Nazwy pokazów nawiązywały do aktualnych wydarzeń w kraju i internetowych trendów (czego przykładem jest chociażby czwarty odcinek drugiego „sezonu”, odwołujący się do kontrowersyjnej wpadki Kamila Durczoka, ówczesnego redaktora naczelnego „Faktów”, dotyczącej brudnego stołu). Ostatni materiał, zatytułowany Wina Tuska, opublikowano we wrześniu 2013 roku.

- MCW - Mine City Wrestling - projekt zainicjowany w 2011 roku przez grupę nastoletnich wówczas miłośników pro wrestlingu z Katowic. Warunkiem dołączenia do zespołu było ukończenie szesnastego roku życia. Kolejne treningi i minipokazy regularnie relacjonowane były w mediach społecznościowych. Mimo ciepłego przyjęcia internautów i zapału organizatorów na przeszkodzie stanęły wysokie koszty wynajmu sal, w których młodzież mogłaby ćwiczyć, a także - co za tym idzie - brak funduszy na rozwój. Grupa próbowała wspierać się kampanią crowdfundingową, ta jednak zakończyła się niepowodzeniem, udało się bowiem zebrać jedynie niewielką część potrzebnej kwoty. Obecnie projekt został zawieszony ${ }^{185}$.

posiada, konstruowany jest przez grupę amatorów z materiałów dostępnych niejako „pod ręką”, nierzadko - z braku innych możliwości - na podwórku prywatnej posesji. To tam pasjonaci organizują skromne pokazy i ćwiczą - bez nadzoru, co znacznie zwiększa ryzyko urazów.

185 Ostatni post na fanpage'u projektu na portalu Facebook pochodzi z kwietnia 2016 roku. https://www.facebook.com/pg/minecitywrestling/ [dostęp: 23.02.2017]. 
- WKSW - Wrestlingowy Klub Sportowy Wołów - projekt grupy pasjonatów z Dolnego Śląska zapoczątkowany w 2010 roku w Wołowie. Wyróżniał się profesjonalnym ringiem oraz szeroko pojętą promocją w mediach (materiały o WKSW emitowane były zarówno w mediach lokalnych, jak i ogólnopolskich), a same pokazy stanowiły istotny element wołowskiej oferty kulturalno-rozrywkowej - zawodnicy związani z grupą niejednokrotnie brali udział w lokalnych festynach i akcjach charytatywnych, występując nawet w ramach 22. Finału Wielkiej Orkiestry Świątecznej Pomocy. WKSW zyskało także aktywne wsparcie Andrzeja Suprona. Grupa zawiesiła działalność w sierpniu 2014 roku, natomiast w marcu 2017 roku zapowiedziane zostało jej wznowienie. Szczegóły przyszłych działań klubu nie są jednak znane.

\subsubsection{Do or Die Wrestling}

Przedsmak obecności profesjonalnych organizacji na polskim rynku można było poczuć w drugiej połowie 2009 roku wraz z założeniem pierwszej w Polsce federacji prowrestlingowej - Do or Die Wrestling. Tego samego dnia ogłoszono także nabór do szkółki, która miała przy niej działać. Inicjatorem przedsięwzięcia był Don Roid, amerykański wrestler mieszkający wówczas w Warszawie. Pierwsze plany Roida wydawały się ambitne - nosił się on bowiem z zamiarem organizacji pokazu w osławionym klubie Stodoła, a wśród występujących mieli się znaleźć między innymi Lanny Poffo (brat ikony Złotej Ery pro wrestlingu, „Macho Mana” Randy'ego Savage) i Austin Aries (wówczas jedna z największych gwiazd sceny niezależnej, obecnie występujący w pokazach federacji WWE). Ze względu na słabą sprzedaż wejściówek ${ }^{186}$ i wycofanie się głównego sponsora event został odwołany.

Prężnie rozwijała się za to szkółka DDW - już kilka tygodni po jej założeniu w warszawskim klubie Karuzela odbył się pokaz pierwszych adeptów, którego gościem specjalnym był światowej sławy kanadyjski wrestler

186 Sprzedano około stu biletów. Na niezadowalające wyniki mogły mieć wpływ zarówno ceny wejściówek (kosztowały od 40 do 140 złotych), jak i przewidywany termin pokazu, kolidujący z szeroko promowaną w mediach walką bokserską Andrzeja Gołoty z Tomaszem Adamkiem. 


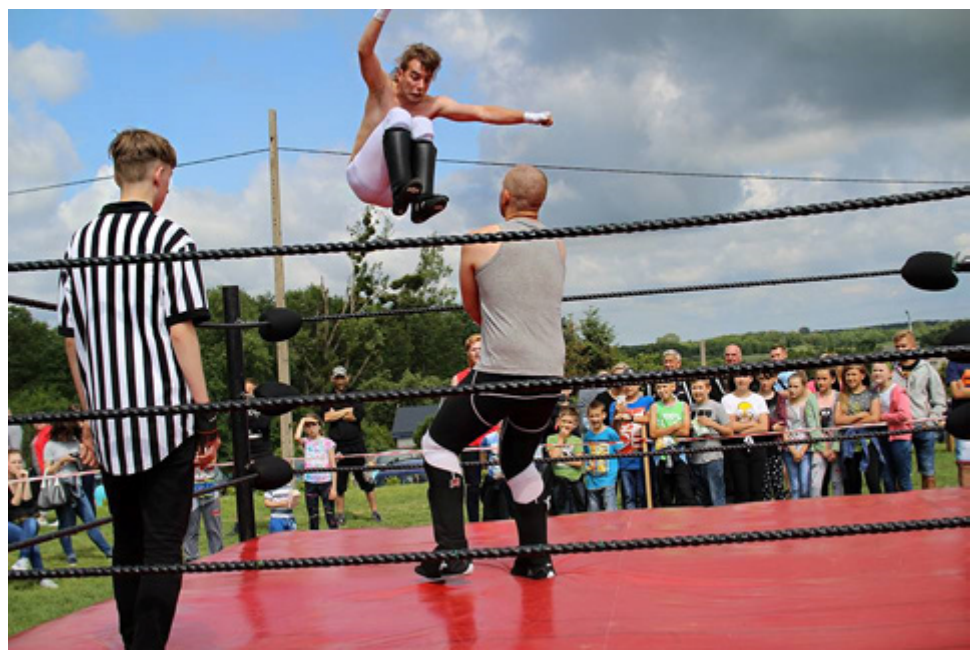

Il. 22. Pokazy backyardowe

El Generico ${ }^{187}$. Pierwsi uczniowie Roida mieli później stanowić trzon polskiego wrestlingu. Na pierwszych pokazach wystąpili między innymi: Klarys, znany ze sceny backyardowej Kamil Aleksander, wcielający się w rolę aroganckiego promotora Pan Pawłowski oraz Jędruś Bułecka ${ }^{188}$, późniejszy współzałożyciel klubu Maniac Zone Wrestling.

Szczytowym osiągnięciem organizacji Dona Roida miała być wielka gala organizowana w łódzkiej Atlas Arenie we współpracy z amerykańską federacją Rivalry Championship Wrestling. Pokaz miał odbyć się 3 listopada 2012 roku, a w ramach walki wieczoru zaplanowano pojedynek bokserów Andrzeja Gołoty i jego rywala sprzed lat, Riddicka Bowe'a. Pojedynek na zasadach pro wrestlingu miał odbyć się w stalowej klatce. Choć brzmi to nieprawdopodobnie, pokaz zapowiadany był w ogólnopolskich mediach, notka informacyjna pojawiła się także na stronie internetowej Atlas Areny.

187 Stoczył on wówczas walkę ze znanym polskiej publiczności także z pokazów TBW Michaelem Kovacem. Obecnie El Generico występuje w pokazach federacji WWE pod pseudonimem Sami Zayn.

188 Bułecka jako jedyny z adeptów DDW posiadał już doświadczenie w pro wrestlingu, przez jakiś czas trenował on bowiem w Szkocji w szkółce Kevina Williamsa. 
Swoją obecność na gali potwierdzili Chris Masters (wrestler polskiego pochodzenia, były zawodnik WWE) i Jimmy Hart (jeden z najbardziej rozpoznawalnych menedżerów w historii dyscypliny), a w spocie promującym wydarzenie wystąpił sam Hulk Hogan ${ }^{189}$. Event zatytułowany Gołota vs Bowe III - Unfinished Business ${ }^{190}$ miał być transmitowany w systemie PPV. W ramach działań promocyjnych odbyła się także konferencja prasowa z udziałem obu bokserów, podczas której doszło do ostrej wymiany zdań (w ramach konwencji kayfabe) oraz typowego dla boksu i mieszanych sztuk walki staredown, czyli spotkania twarzą w twarz. Do walki ostatecznie nie doszło, a sam pokaz został odwołany. Oficjalnym powodem podanym przez organizatorów była kontuzja Riddicka Bowe’a, choć pojawiły się pogłoski, jakoby Andrzej Gołota miał dostać propozycję innej, bardziej lukratywnej walki. Podczas gali Polsat Boxing Night 2013 bokser zmierzył się bowiem z Przemysławem Saletą.

Organizacja Do or Die Wrestling działała do 2015 roku. Do tego czasu Donowi Roidowi udało się zorganizować kilkanaście pokazów w kilku miastach Polski (między innymi w Rzeszowie i Gdańsku), a także - we współpracy z zagranicznymi promotorami - na Węgrzech i w Wielkiej Brytanii. Wytrenował on także kilkudziesięciu performerów, w tym kilka kobiet $^{191}$. Klub aktywnie promowano w mediach społecznościowych, a na serwisie YouTube umieszczane były między innymi skróty pokazów, wideorelacje z kursów i treningów, a także krótkie filmy zarysowujące fabułę rywalizacji pomiędzy poszczególnymi zawodnikami i zawodniczkami. Ostatnie show DDW odbyło się w ramach trójmiejskiego festiwalu Balticon w 2015 roku - wkrótce potem Roid postanowił wrócić do Stanów Zjednoczonych. Pozostałym członkom klubu udało się jednak odkupić od

189 Zob. Jimmy Hart i Hulk Hogan zapraszaja na walkę Andrzej Gołota vs Riddick Bowe, https://www.youtube.com/watch?v=5HuloTDVmv0 [dostęp: 1.03.2017].

190 Czyli „niedokończone porachunki”. Nazwa ta bezpośrednio nawiązywała do kontrowersyjnego pojedynku bokserskiego z 1996 roku, który zakończył się dyskwalifikacją, gdy Gołota zdecydował się wykonać kilkanaście ciosów poniżej pasa.

191 Najbardziej rozpoznawalną zawodniczką wytrenowaną przez Dona Roida jest pochodząca z Zielonej Góry Bianca, związana z DDW niemalże od samych początków klubu. 
niego ring i rozpocząć działalność nowej grupy - Kombat Pro Wrestling która działa do dziś.

\subsubsection{Total Blast Wrestling}

Także w 2009 roku ogłoszono termin pierwszego pokazu konkurencyjnej marki. Kameralny event Total Blast Wrestling odbył się 27 lutego 2010 roku w radomskim klubie Strefa G2, zgromadziwszy pokaźną (jak na standardy organizacji niezależnych) widownię ${ }^{192}$. Przygotowaniem pokazu zajęli się wcześniej wspomniani Paweł Borkowski i Andrzej Supron, którzy nawiązali współpracę z belgijskim klubem Eurostars zrzeszającym zawodników z całego kontynentu. Na gali doszło do obrony prestiżowego mistrzostwa Europy (ówczesny mistrz, pochodzący z Belgii Bernard Vandamme, zmierzył się ze szkockim olbrzymem Colossosem), a także wyłonienia nowego pretendenta do tytułu mistrzowskiego. Nie zabrakło również polskich akcentów - w pokazie wzięli udział Kamil Bazelak, znany strongman i zawodnik mieszanych sztuk walki, oraz tajemniczy mnich August. Pokazowi towarzyszył krótki koncert lubelskiego zespołu heavymetalowego Enthymion ${ }^{193}$.

Organizatorzy, zachęceni sukcesem pierwszego eventu, przygotowali drugi pokaz Total Blast Wrestling, który odbył się 5 czerwca 2010 roku w hali OSiR w Zawierciu. Tym razem poza zawodnikami związanymi z Eurostars w pokazie wystąpili także przedstawiciele lucha libre (Ultimo Chingon) oraz puroresu (Makoto Morimitsu). Oprócz walki w formule Mexico vs Japan galę uświetnił widowiskowy pojedynek typu TLC ${ }^{194}$ oraz kolejna obrona mistrzostwa Europy. W przerwach między potyczkami ring przejmowały dziewczęta z grupy tanecznej działającej przy miejscowym domu kultury. Mimo że licznie zgromadzeni fani chwalili dobrą organizację wydarzenia

192 http://totalblast.pl/ [dostęp: 24.02.2017].

193 Zespół przygotował na tę okazję zupełnie nowy utwór, który użyty został jako motyw przewodni eventu.

194 Skrót od angielskiej nazwy Tables, Ladders \& Chairs. Jest to pojedynek bez możliwości dyskwalifikacji, w którym dozwolone jest używanie wszelkich narzędzi i tak zwanych foreign objects (przedmiotów zabronionych w normalnych starciach), ze szczególnym wskazaniem na tytułowe stoły, drabiny i krzesła. Walkę wygrać można przez ściągnięcie zawieszonego nad ziemią trofeum (najczęściej pasa mistrzowskiego). 
i wysoki poziom prezentowany przez zawodników, wydarzenie nie zainteresowało potencjalnych sponsorów, co ostatecznie przekreśliło szanse na kolejne pokazy TBW. Ostatnia aktualizacja strony internetowej organizacji pochodzi z 2011 roku.

\subsubsection{Maniac Zone Wrestling}

Najmłodszą polską organizacją prowrestlingową jest wrocławska Maniac Zone Wrestling. Choć pierwsze treningi odbyły się jeszcze w 2013 roku, oficjalnie zarejestrowana została dopiero na początku 2014 roku. Klub dysponuje profesjonalnym ringiem, zatrudnia konferansjerów i zawodowych sędziów. Opiekę merytoryczną zapewnia Jędruś Bułecka - uczeń szkockiego zapaśnika Kevina Williamsa i zarazem adept szkoły Dona Roida.

Wieść o powstaniu MZW została ciepło przyjęta przez rodzimą społeczność internetową. Jak można przeczytać na fanpage’u organizacji na portalu społecznościowym Facebook, priorytetem organizatorów było stworzenie profesjonalnego i dojrzałego produktu, a także nawiązanie międzynarodowej współpracy ${ }^{195}$. Przewidywanym terminem pierwszych pokazów miał być wrzesień 2014 roku, jednak ze względu na zadowalające zainteresowanie produktem oraz zaangażowanie członków MZW udało się go zorganizować z kilkumiesięcznym wyprzedzeniem. Pierwszy pokaz adeptów szkółki treningowej Jędrusia Bułecki odbył się 10 maja 2014 roku, natomiast pierwsza profesjonalna gala - 21 czerwca 2014 roku w podwrocławskim Smolcu ${ }^{196}$. Dotychczas udało się zorganizować dwadzieścia pokazów, w tym kilka płatnych ${ }^{197}$. MZW zaangażowało się także w działalność charytatywną, trzykrotnie już przygotowując biletowane pokazy z okazji dorocznego finału Wielkiej Orkiestry Świątecznej Pomocy ${ }^{198}$.

195 https://www.facebook.com/ManiacZoneWrestling/?fref=ts [dostęp: 27.02.2017].

196 Pokaz ten odbył się w ramach cyklicznego festynu z okazji Dni Smolca i zgromadził nieco ponad dwustu widzów. Wstęp był bezpłatny.

197 Niewątpliwą zaletą był przystępny koszt wstępu na pokazy. Ceny wejściówek wahały się bowiem od kilku do kilkunastu złotych.

198 Cały dochód z owych pokazów przekazywany był fundacji Jurka Owsiaka. 
Koniec maja 2015 roku przyniósł polskim fanom pro wrestlingu przykre wieści. Podczas pierwszego płatnego pokazu MZW ${ }^{199}$ doszło do tragedii - w pierwszym w historii klubu pojedynku kobiet zmierzyły się ze sobą Hexia i zaledwie szesnastoletnia Akira. Po zakończeniu walki ta druga nie była w stanie podnieść się z maty. Pokaz przerwano, a młodą zawodniczkę przewieziono do najbliższego szpitala. Kilka dni później klub poinformował o śmierci dziewczyny i zawieszeniu działalności do czasu wyjaśnienia sprawy. Jak się okazało, przyczyną tragedii nie były obrażenia odniesione w trakcie pokazu (jak początkowo podejrzewano), a ukryty tętniak, o którym nie wiedziała nawet najbliższa rodzina nastolatki. Zwolnienie od odpowiedzialności za jej śmierć umożliwiło dalsze funkcjonowanie MZW.

Klub dynamicznie rozwija się, poszerzając współpracę międzynarodową. W pokazach i treningach biorą udział wrestlerzy z całej Europy (związani głównie z niemieckim klubem Next Step), a same gale cieszą się zadowalającym zainteresowaniem.

\subsection{PERSPEKTYWY NA PRZYSZŁOŚĆ}

Warto wspomnieć, że zawodowa kariera zapaśnicza nie jest jeszcze w Polsce możliwa. Jak zauważa Patryk Gołąb, występujący na pokazach organizacji Maniac Zone Wrestling jako „książę polskiego wrestlingu” - Prince Victor, dyscyplina ta wciąż nie jest na tyle popularna, by mogła stanowić główne źródło utrzymania. „Póki co tylko się tym bawimy - mówi - i tak zostanie jeszcze przez długi czas"200. Udział w pokazach performerzy traktują hobbystycznie, niejako w oderwaniu od kariery zawodowej. Przykładowo, Pan Pawłowski na co dzień zajmuje się dziennikarstwem sportowym, próbuje również swych sił na scenie kabaretowej. Agnieszka Przyborowska-Mitrosz, występująca w MZW jako Hexia, jest programistką, a Jędruś Bułecka... wykładowcą akademickim.

Organizatorzy z kolei uzależnieni są najczęściej od zewnętrznych sponsorów i dodatkowych środków, jakie udaje im się zgromadzić, na przykład

199 Pokaz MZW Champions War I odbył się 31 maja 2015 roku w podwrocławskich Głuchołazach i zgromadził ponad stu widzów.

${ }^{200}$ Fragment rozmowy z Patrykiem Gołębiem / Princem Victorem, zawodnikiem organizacji Maniac Zone Wrestling, którą przeprowadziłam na potrzeby niniejszej pracy. 
pobierając opłaty za treningi lub organizując mniejsze pokazy „na zamówienie"201. Bilety na pokazy i licencjonowane towary (głównie koszulki i pamiątkowe plakaty) są dodatkowym, choć drobnym, źródłem dochodów, w dużej mierze przeznaczanym na opłaty za wynajem sal lub konserwację ringu. Słowem, na pro wrestlingu w Polsce jeszcze się nie zarabia.

\section{EPILOG - CIĄG DALSZY NASTĄPI...}

3 kwietnia 2016 roku na trybunach stadionu AT\&T w teksańskim Arlington zasiadło ponad sto tysięcy widzów ${ }^{202}$. Fani z całego świata zgromadzili się, by na własnej skórze doświadczyć fenomenu Wrestlemanii - święta sportowego teatru i przemysłu rozrywkowego, celebracji cielesnej różnorodności i seksualnej subwersji; by wziąć udział w kampowym, kontrkulturowym karnawale, śledzić metatekstowe nawiązania, a swoją wiedzę - czerpaną $\mathrm{z}$ insiderskich mediów i forów internetowych - zderzyć z kompleksowymi planami promotorów; by - w końcu - dobrze się bawić, jako że rozrywka sportowa - tak jak i każda inna forma rozrywki - ma przede wszystkim służyć jako chwilowe oderwanie się od prozy dnia codziennego.

Celem niniejszego tekstu było uchwycenie istoty i kulturowego znaczenia pro wrestlingu. Nie sposób jednak zmieścić przeszło półtora wieku kumulowania kontekstów na kilkudziesięciu stronach rozprawy. Co więcej, za kilka lat rozważania te mogą częściowo stracić swoją aktualność - wszak pro wrestling pozostaje w pewnym sensie płynny, podatny i wrażliwy na wpływy rzeczywistości, z której czerpie inspiracje i którą trawestuje. Mimo utrwalonych przez dziesięciolecia form i archetypów, a także powtarzalnych modeli narracyjnych, wrestling - jako widowisko o charakterze sportowym - wciąż funkcjonuje przedstawieniowo, to jest jako zbiór niepowtarzalnych, unikalnych przedstawień ${ }^{203}$. Aby treści wydawały się aktualne, promotorzy zobowiązani są reagować na zmieniające się trendy i odpowiadać na oczekiwania wymagającej bazy odbiorców. I choć żadnemu z nich zapewne nigdy nie będzie już dane powtórzyć sukcesów Ery Attitude czy Rock \& Wrestling

201 Klub Maniac Zone Wrestling za pośrednictwem strony internetowej oferuje swoje usługi na różne okazje, między innymi: przyjęcia urodzinowe, wieczory panieńskie i kawalerskie, zjazdy integracyjne i imprezy firmowe.

${ }^{202}$ Według oficjalnych danych udostępnianych przez WWE.

203 D. Kosiński, op. cit., s. 21. 
Connection, jedno wydaje się przy tym pewne - pro wrestling na tyle silnie zakorzenił się w amerykańskiej popkulturze, iż śmiało można uznać go za jej integralną i reprezentatywną część. Być może właśnie w prostocie i elastyczności przekazu leży źródło długotrwałej popularności widowiska, otwartego na wszelkie odmienności, a tym samym gotowego stworzyć i zapełnić każdą niszę bez obawy o narażenie się na śmieszność.

\section{Bibliografia}

Walter Anderson, Wrestling, F.A. Stokes Company, New York 1890.

Roland Barthes, Świat wolnoamerykanki, [w:] idem, Mitologie, tłum. A. Dziadek, Aletheia, Warszawa 2008.

Judith Butler, Od „wnętrza” do performatywnej ptci, tłum. K. Krasuska, [w:] Kamp. Antologia przekładów, red. P. Czapliński, A. Mizerka, Universitas, Kraków 2012.

Gordon Calleja, Constantino Oliva, Fake Rules, Real Fiction: Professional Wrestling and Videogames, http://www.digra.org/digital-library/publications/ fake-rules-real-fiction-professional-wrestling-and-videogames/.

Gino Canella, Occupy Raw: Pro Wrestling Fans, Carnivalesque, and the Commercialization of Social Movements, „The Journal Of Popular Culture” 2016, vol. 49, nr 6 .

Christopher Charlton, Lion's Pride: the turbulent history of New Japan Pro Wrestling, self-published, 2015.

John Fiske, Wyzywająca cielesność i przyjemności karnawałowe, [w:] idem, Zrozumieć kulturę popularna, tłum. K. Sawicka, Wydawnictwo Naukowe UJ, Kraków 2010.

Donald Horton, Richard Wohl, Komunikacja masowa i paraspołeczna interakcja. Uwagi o intymności na odległość, [w:] Pejzaże audiowizualne: telewizja, wideo, komputer, oprac. A. Gwóźdź, Universitas, Kraków 1997.

Chris Jericho, Undisputed. How To Become The World Champion In 1,372 Easy Steps, Orion Books, London 2011.

Chris Jericho, The Best In The World At What I Have No Idea, Gotham Books, New York 2014.

Chris Kelly, The New Day and Being Black In WWE, https://sports.vice.com/en_ca/ article/xybz4d/the-new-day-and-being-black-in-wwe. 
Dariusz Kosiński, Performatyka i dramatologia sportu. Próba przewrotki teoretycznej, „Kultura Współczesna” 2017, nr 1.

Sharon Mazer, Professional wrestling. Sport and spectacle, University Press of Mississippi, Jackson 1998.

Bolesław Racięski, Zamaskowani zapaśnicy na granicy światów. Lucha libre na ringu i w kinie jako przykład popkulturowego synkretyzmu, [w:] Synkretyzm nowego świata, red. Paweł Kalina, AT Wydawnictwo, Kraków 2015.

Bolesław Racięski, Zapaśnik bawi i uczy. Społeczne funkcje filmów o Santo, [w:] Bękarty kinematografii, czyli rzecz o filmach nie(do)cenionych, red. J. Łuniewicz, F. Nowak, B. Racięski, Yohei, Wrocław 2014.

Susan Sontag, Notatki o kampie, tłum. W. Wartenstein, „Literatura na Świecie” 1979, nr 9.

The History Of Lucha Libre, https://web.archive.org/web/20120913065250/http:// www.bongo.net/papers/lucha.htm.

\section{Filmografia}

Człowiek z księżyca, reż. Miloš Forman, 2000.

Hitman Hart: wrestling z cieniami, reż. Paul Jay, 1998.

Kibice do dzieła!, reż. Brian Robbins, 2000.

Zapaśnik, reż. Darren Aronofsky, 2008.

\section{Wykaz źródeł ilustracji}

Il. 1. W. Anderson, Catch-as-catch-can style, [w:] idem, Wrestling, New York 1890, s. 40. Dostępny online: https://ia800504.us.archive.org/12/items/ Wrestling_897/Wrestling.pdf.

Il. 2. W. Anderson, Cornish and Devonshire styles, [w:] idem, Wrestling, New York1890, s. 19. Dostępny online: https://ia800504.us.archive.org/12/items/ Wrestling_897/Wrestling.pdf.

Il. 3. https://www.skysports.com/wwe/news/14203/11210245/raw-25-when-d -generation-x-invaded-wcw-nitro.

Il. 4. https://ewrestling.com/sites/default/files/styles/article_main_photo_1284x722/ public/2017-01/wrestlemania-30-new-orleans-600x400.jpg?itok=3Cqz4IDq.

Il. 5. http://3.bp.blogspot.com/-0ELufIaiZHQ/VIxRdL9-DzI/AAAAAAAAE8Q/M_ mLIrwX1TM/s1600/2010.png.

Il. 6. https://www.inquisitr.com/sitemaps/content/wwe-news-elimination-chamber-returning-talking-stick-arizona.jpg. 
Il. 7. http://cynosuregaming.com/wp-content/uploads/2017/08/Roode.jpg.

Il. 8. https://www.wwe.com/f/all/2017/01/025_RR_01292017ej_0067--47cbla96ff84 ad78903af38220639013.jpg.

Il. 9. C. Jericho, The Best In The World At What I Have No Idea, New York2014, s. 271.

Il. 10. https://www.wwe.com/f/styles/wwe_large/public/rd-talent/Bio/Stardust_bio. png.

Il. 11. http://wrestlespot.pl/wp-content/uploads/2017/08/Ric_Flair_bio.jpg.

Il. 12. https://www.wwe.com/f/styles/gallery_img_1/public/2016/04/47_WM13_ 03231997_0275--cc2599837265c99a68a073fc7f423af2.jpg.

Il. 13. https://www.wwe.com/f/styles/gallery_img_1/public/photo/image/2015/ 01/006_03_001_aSAMOAN_00000000_0002-2277336377.jpg.

Il. 14. https://statics.sportskeeda.com/wp-content/uploads/2016/04/25db68c2f49c7da159c4a9b8301463c6_original-1459859122-800.jpg.

Il. 15. https://s3.scoopwhoop.com/anj/austin/c3b45ffc-5868-4745-a44b-371f9ebfdlbf. jpg.

Il. 16. https://www.wwe.com/f/styles/gallery_img_1/public/all/2017/09/024_ RAW_05212001_0029--e084c8136e567aa266d7d8c81bf56c0f.jpg.

Il. 17. http://www.onlineworldofwrestling.com/wp-content/uploads/2012/06/35_ Tag_Sheik_Volkoff.jpg.

Il. 18. https://www.lapatilla.com/wp-content/uploads/2015/07/WWE-Bu dget-Cuts-Cause-Superstar-Santino-Marella-To-Retire.png ?zoom $=2 \&$ resize $=640 \% 2 \mathrm{C} 400$.

Il. 19. https://img.bleacherreport.net/img/images/photos/002/795/029/63b85 0101e1412f4dae0089a5f412b6d_crop_exact.jpg?w=1200\&h=1200\&q=75.

Il. 20. https://bloximages.chicago2.vip.townnews.com/siouxcityjournal.com/ content/tncms/assets/v3/editorial/d/63/d632750f-ddda-5689-84af-db0e6f83711d/5494d4968987e.preview-699.jpg?crop=699\%2C393\%2C0\%2C33\&resize $=699 \% 2$ C393\&order $=$ crop\%2Cresize.

Il. 21. https://statics.sportskeeda.com/wp-content/uploads/2017/04/stong-robocop-1492847717-500.jpg.

Il. 22. https://cheappopculture.files.wordpress.com/2017/07/img_7173-e14998 25675608.png.

Il. 23. http://www.sinfinalenelguion.net/wp-content/uploads/2016/05/venganzade-las-mujeres-vampiro-santo-1-g.jpg. 
Il. 24. https://scontent-any2-1.xx.fbcdn.net/v/t1.0-9/20728387_1408532825883156_ 6309253503249676342_n.jpg?_nc_cat=110\&_nc_ht=scontent-any2-1.xx\&oh $=667 \mathrm{ba} 35589644 \mathrm{baa} 371 \mathrm{a} 75980430 \mathrm{a} 018 \&$ oe $=5 \mathrm{CFC} 018 \mathrm{~B}$.

\section{Modern-day Gladiators. An Attempt to Determine the Essence and the Cultural Significance of the Pro Wrestling}

Professional wrestling is a polarizing phenomenon, adored for its excessive nature, yet still categorized as 'fake'. Under the surface of a simple form of mass entertainment there are plenty of cultural contexts to be found, from the carnivalesque nature of the show itself, the stereotype issues, the subversion of standards, to its area of social transgression. This article presents sports entertainment as a multi-layered and intermedial phenomenon, especially representative of the American mass culture.

Keywords: wrestling, camp, transgression, mass culture, body, stereotype, pop culture, gender, performance 